\title{
EXPERIENCE WITH CARBON TAXES AND GREENHOUSE GAS EMISSIONS TRADING SYSTEMS
}

\author{
ERIK Haites, DUAN MAOSHENG, Kelly Sims GallaGHER, \\ SHARON MASCHER, EASWARAN NARASSIMHAN, KENNETH R. \\ RICHARDS, \& MASAYO WAKABAYASHI*
}

Carbon taxes and emissions trading systems (ETSs) to limit emissions of greenhouse gases (GHGs) are increasingly common. At the end of 2015, 17 GHG ETSS were operational in 55 jurisdictions, and 18 jurisdictions collected at least one carbon tax. This paper assesses the performance of carbon taxes and ETSs with respect to environmental effectiveness (reduction of emissions regulated by the instrument), costeffectiveness (marginal abatement cost), economic efficiency, public finance, and administrative issues.

Data on emissions subject to carbon taxes are rarely reported. We estimate the taxed emissions for 17 taxes in 12 jurisdictions from 1991 through the end of 2015. All 17 taxes have reduced emissions relative to

Copyright () 2018 Erik Haites, Duan Maosheng, Kelly Sims Gallagher, Sharon Mascher, Easwaran Narassimhan, Kenneth R. Richards, \& Masayo Wakabayashi.

* Erik Haites is President of Margaree Consultants Inc., Toronto, Canada; Duan Maosheng is Associate Professor at the Institute of Energy, Environment and Economy and China Carbon Market Center, Tsinghua University, Beijing, People's Republic of China; Kelly Sims Gallagher is Professor of Energy and Environmental Policy, and Director of the Center for International Environment and Resource Policy, The Fletcher School, Tufts University, Medford, Massachusetts, USA; Sharon Mascher is Professor Law at Faculty of Law at the University of Calgary, Calgary, Alberta, Canada and Honorary Fellow in the Law School at the University of Western Australia; Easwaran Narassimhan is Research Fellow at the Climate Policy Lab at the Center for International Environment and Resource Policy, The Fletcher School, Tufts University, Medford, Massachusetts, USA; Kenneth R. Richards is Professor of Environmental and Energy Policy, School of Public and Environmental Affairs, Affiliated Professor of Environmental and Energy Law at the Maurer School of Law, and Affiliated Faculty, Vincent and Elinor Ostrom Workshop in Political Theory and Policy Analysis Indiana University, Bloomington, Indiana, USA. Masayo Wakabayashi is a Researcher at the Socio-Economic Research Center, Central Research Institute of Electric Power Industry and doctoral student in Graduate School of Economics, Waseda University, Tokyo, Japan. Special thanks to Stefan Ulrich Speck for invaluable assistance with sources for carbon tax data. Constructive comments on earlier drafts were provided by Thomas Calkin, James Mak, Stephen Seres, Stefan Ulrich Speck, Gray Taylor and Ralph Torrie. Matthew Metz provided editorial assistance. The authors are solely responsible for all errors, omissions and opinions. 
business-as-usual. Six of the jurisdictions actually reduced emissions, although in at least three of those jurisdictions the reductions appear to be due to other policies. The small sizes of reduction in almost all 17 cases are partially due to the low tax rates; the modest and uncertain changes in tax rates over time; and the limited response of taxed sources, such as fossil fuels, to price changes.

Actual emissions declined for at least six of 10 ETSs. Other policies and developments, such as the 2009 recession, contributed to the reductions, but estimates of the share of the reduction attributable to the instrument are rare. All of the ETSs have accumulated banks of surplus allowances and most have implemented measures to reduce these banks. On average, the marginal cost of compliance is substantially lower for ETSs than carbon taxes.

ETS experience has been shared bilaterally and via dedicated institutions. As a result, most ETSs have increased the share of allowances auctioned; adopted declining emissions caps; specified future caps and floor prices several years into the future; shifted to benchmarking for free allowance allocations to emissions-intensive, trade-exposed (EITE) sources; reduced accessibility to foreign offset credits; and established market stability reserves. By contrast, there is little evidence of shared learning and virtually no change to the design of carbon taxes. We found no jurisdiction that routinely tracks the taxed emissions. Very few jurisdictions regularly assess the effectiveness of the tax in achieving emission reductions. Additionally, adjustments to the tax rate often are unpredictable after an introductory period of three to five years.

Both instruments reduce emissions, but ETSs have performed better than carbon taxes on the principal criteria of environmental effectiveness and cost-effectiveness. Many jurisdictions have implemented both a carbon tax and a GHG ETS, and every jurisdiction that has adopted either instrument has also implemented other policies. More research is needed to improve the design of both instruments and their interaction with non-market-based carbon policies because the use of multiple instruments produces complex interactive and distributional effects. While economically inefficient, market-based policies should be supplemented by non-market-based policies to ensure sustained political support.

\section{INTRODUCTION}

Whether carbon taxes or greenhouse gas (GHG) emissions trading systems (ETSs) are more effective at reducing GHG emissions 
has been widely debated in climate policy literature. ${ }^{1}$ Lacking from this debate is empirical evidence documenting the performance of these instruments. This paper fills the gap by providing such evidence.

Economic theory indicates that pricing ${ }^{2} \mathrm{GHG}^{3}$ emissions can minimize the cost to society of reducing emissions and so mitigating climate change. Carbon taxes and ETSs are two ways to price GHG emissions. A carbon tax imposes a price - the tax rate specified by the government-on each metric ton of GHGs emitted, measured as metric ton of carbon dioxide equivalent $\left(\mathrm{tCO}_{2} \mathrm{e}\right)$, but does not limit overall emissions. ${ }^{4}$ A cap-and-trade system-the most common form of ETS - imposes a government-established limit on aggregate GHG emissions by specified sources, distributes tradable allowances (usually one $\mathrm{tCO}_{2} \mathrm{e}$ each) approximately equal to the limit, and requires regulated emitters to submit allowances equal to their actual emissions. ${ }^{5}$ The market determines the price for allowances and thus the price per $\mathrm{tCO}_{2} \mathrm{e}$ emitted. A baseline-and-credit system-a less common form of ETS - specifies an absolute emissions or emissions intensity limit for each participant and allocates tradable credits ("allowances") to emitters who emit less than their limits. Emitters that exceed their limits can purchase credits from other participants to cover the excess emissions. Again, the market determines the price per $\mathrm{tCO}_{2} \mathrm{e}$ emitted.

1. See, e.g., Shi-Ling Hsu, The CaSe fOR a Carbon TaX: Getting Past Our HangUps to EFFective Climate Policy 5-7 (2012); World Bank P'ship fOR MARKeT ReAdiness, CARbon TAX Guide: A Handbook For Policy MaKers 34 (2017); Michael Goldblatt, Comparison of Emissions Trading and Carbon Taxation in South Africa, 10 CLIMATE POL'Y 511, 512-13 (2011); Michael G. Pollitt, A Global Carbon Market? 7 (Energy Pol'y Research Grp., Univ. Cambridge, Working Paper No. 1608, 2016).

2. See, e.g., Andrea Baranzini et al., Carbon Pricing in Climate Policy: Seven Reasons, Complementary Instruments, and Political Economy Considerations, 8 WIREs Climate CHANGE, Dec. 2017, 3-6 [hereinafter Seven Reasons].

3. There are numerous GHGs. Carbon dioxide (CO2) is the most voluminous and least potent. Emissions of other GHGs are often measured in terms of tons of $\mathrm{CO} 2$ equivalence (tCO2e) usually based on their radiative forcing relative to $\mathrm{CO} 2$ over 100 years. See SUSAN Solomon et al., Intergovernmental Panel on Climate Change, Climate Change 2007: THE PHYSICAL SCIENCE BASIS 33 (2007).

4. A carbon tax is a tax per tCO2e applied to fossil fuels and/or GHG emitting activities. In this paper, taxes on fossil fuels not related to the GHG emissions due to combustion of the fuel are not considered to be carbon taxes.

5. The quantity of allowances distributed may be less than the established limit because some allowances may be withheld for various purposes, such as allocations to new entrants, or because they are not purchased at allowance auctions. Allowances in excess of the cap may be distributed as transitional mechanisms, such as credit for early action, or to limit price increases when allowance prices exceed specified thresholds. 
A carbon tax and an ETS would yield identical results for equivalent emission reductions if there is no uncertainty regarding future prices, perfect competition in all markets, no interaction with other policies, and universal coverage (all sources of GHG emissions). In practice, the performance of carbon taxes differs from that of ETSs because these assumptions never hold. In a given jurisdiction, various factors including taxation authority, the emissions profile, and influence of large emitters can affect the choice and design of an instrument. Thus, the designs of carbon taxes and GHG ETSs, as well as their performance, vary across jurisdictions.

The performance of a carbon tax or ETS as implemented is further affected by some of the jurisdiction's other emissions-related policies, such as fuel taxes, energy efficiency standards, and renewable energy incentives. ${ }^{6}$ External factors, such as economic recessions, fossil fuel prices, and natural disasters, ${ }^{7}$ can affect the emission reductions achieved by a tax or ETS. ${ }^{8}$

This paper assesses the performance of carbon taxes and GHG ETSs operational at the end of 2015. ${ }^{9}$ These instruments are assessed for environmental effectiveness (reduction of actual emissions), costeffectiveness (marginal abatement cost), economic efficiency, public finance, and administrative issues. We do not make any causal claims between the observed emission reductions in a jurisdiction and its choice of policy instrument because, as noted above, many other factors affect actual emissions. The data and resources needed to disentangle the contribution of the instrument from the other factors were not available for this research. Nevertheless, useful insights can be drawn about the performance of the carbon taxes and GHG ETSs implemented to date.

6. See generally OECD, INTERACTIONS BETWEEN EMISSION TRADING SYSTEMS AND OTHER OVERLAPPING POLICY INSTRUMENTS (2011) (describing interactions between emissions trading schemes and other policy tools); Baranzini et al., supra note 2, at 6-7.

7. See, e.g., Martin Fackler, Nuclear Power Nears Standstill for the Japanese, N.Y. TIMES, Mar. 8, 2012, at A1 (describing dip in nuclear power production after Fukushima earthquake and tsunami).

8. For example, the economic recession of 2009 reduced GHG emissions by sources subject to several carbon taxes (see Annex 1). A decline in natural gas prices in the US due to shale gas production led to fuel switching and lower emissions by Regional Greenhouse Gas Initiative (RGGI) participants. Brian C. Murray \& Peter T. Maniloff, Why Have Greenhouse Emissions in RGGI States Declined? An Econometric Attribution to Economic, Energy Market, and Policy Factors, 51 ENERGY ECON. 581, 583-84 (2015).

9. Taxes and ETSs that are no longer operational, such as Australia's carbon pricing mechanism that was repealed in 2014 are not included in the analysis. Clean Energy Legislation (Carbon Tax Repeal) Act 2014 (Austl.) (repealing the Clean Energy Act 2011). 
The performance of many of the instruments implemented has been assessed from several different perspectives and with varying degrees of rigor, including those implemented by Alberta, British Columbia, California, Denmark, European Union ETS, Finland, Ireland, New Zealand, Norway, Regional Greenhouse Gas Initiative (RGGI), Sweden, and Switzerland. ${ }^{10}$ In addition to assessments of individual instruments, a few studies review the performance of multiple instruments including the seven Chinese pilot ETSs, ${ }^{11}$ ETSs for GHGs and other pollutants,${ }^{12}$ carbon taxes in multiple European countries, ${ }^{13}$ and carbon taxes and GHG ETSs in eighteen jurisdictions. ${ }^{14}$

This article proceeds as follows. Section I identifies the carbon taxes and GHG ETSs implemented before the end of 2015. Section II discusses the effect of real-world considerations on instrument choice and design. Criteria to evaluate the instruments are proposed in Section III. The changes in emissions subject to the carbon taxes and GHG ETSs implemented to-date are summarized in Sections IV and $\mathrm{V}$, respectively. Our assessment of the performance of these instruments in practice appears in Section VI. Section VII concludes.

\section{CARBON TAXES AND GHG ETSS IMPLEMENTED BY THE END OF 2015}

Our analysis is limited to the instruments operational at the end of 2015 because sufficient data to assess the performance of more recently implemented instruments are not available. Subsequent market-based emissions policy implementations include carbon taxes adopted in Alberta (Canada), Chile, and Columbia in 2017 and ETSs

10. Summaries of the assessments are provided in section IV.B for taxes and section V.C for ETSs.

11. See generally Zhe Deng et al., Effectiveness of Pilot Carbon Emissions Trading Systems in China, 18 Climate Pol'y 992 (2018); Jun Dong et al., From Pilot to the National Emissions Trading Scheme in China: International Practice and Domestic Experiences, 8 SUSTAINABILITY 522 (2016); Maosheng Duan et al., Review of Carbon Emissions Trading Pilots in China, 25 ENERGY \& ENV. 527 (2014); Junjie Zhang et al., Lessons Learned from China's Regional Carbon Market Pilots, 6 ECON. ENERGY \& ENVTL. POL'Y 1 (2017).

12. See generally Richard Schmalensee \& Robert N. Stavins, Lessons Learned from Three Decades of Experience with Cap-and-Trade, 11 REV. ENVTL. ECON. \& POL'Y 59 (2017).

13. See generally TORbEN MideKSA \& STEFFEN KALLBEKKEN, CTR. FOR INT'L Climate

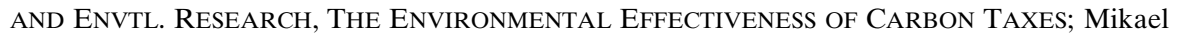
Skou Andersen, Europe's Experience with Carbon-Energy Taxation, 3 S.A.P.I.EN.S, Dec. 2010; Boqiang Lin \& Xuehui Li, The Effect of Carbon Tax on Per Capita CO2 Emissions, 39 ENERGY POL'Y 5137 (2011).

14. See Easwaran Narassimhan et al., CARbon Pricing in Practice: A Review of THE EVIDENCE (Climate Policy Lab, The Fletcher Sch., Tufts Univ., No. 015, 2017). 
implemented in Fuijan (China) in 2016 and Ontario (Canada) in 2017. Among them, Alberta's ETS - the Specified Gas Emitters Regulation (SGER) - has been replaced by an updated emissions intensity baseline and credit ETS; ${ }^{15}$ the Ontario ETS was terminated by a new provincial government in 2018; ${ }^{16}$ and though British Columbia (Canada) has passed legislation that enables the establishment of a baseline-and-credit ETS, the system has not yet been operationalized. 17

At the end of 2015, GHG ETSs were operational in 55 jurisdictions (34 national and 21 sub-national),$^{18}$ and 18 jurisdictions (17 national and one sub-national) collected at least one carbon tax. Table 1 lists these jurisdictions and their policy instruments. ${ }^{19}$ ETSs were implemented in a greater number of jurisdictions and covered a greater percentage of priced emissions than carbon taxes. Of the 6,059 $\mathrm{MtCO}_{2} \mathrm{e}$ annual emissions covered by a carbon price at the end of 2015, ETSs covered 4,286 $\mathrm{MtCO}_{2} \mathrm{e}(71 \%)$, while carbon taxes covered 1,773 $\mathrm{MtCO}_{2} \mathrm{e}(29 \%) .{ }^{20}$ Although ETSs are more common, they were adopted much later than carbon taxes. The first carbon taxes were adopted in 1990, while the first GHG ETS still in effect was not implemented until 2005.

The average share of a jurisdiction's emissions covered by an ETS $(48.0 \%)$ is a little higher than the average for a carbon tax $(45.7 \%) .{ }^{21}$ The share of emissions covered ranges from $18 \%$ to $85 \%$ for ETSs and from $3 \%$ to $70 \%$ for carbon taxes. The average tax rate (USD 13.04

15. Sharon Mascher, Striving for Equivalency Across the Alberta, British Columbia, Ontario and Québec Carbon Pricing Systems: The Pan-Canadian Carbon Pricing Benchmark, 18 CliMATE POL'Y 1012, 1015 (2018). As of 2017, the fixed price compliance option under the revised system was CAD 30, the price shown in Table 1. As this paper focuses on ETSs operational in 2015, unless otherwise specified, statements relating to Alberta's ETS refer to the SGER. Id.

16. Id.

17. Id.

18. The EU ETS covers 31 national jurisdictions (the 28 member states plus Iceland, Norway and Liechtenstein) and RGGI covers nine American states (Connecticut, Delaware, Maine, Maryland, Massachusetts, New Hampshire, New York, Rhode Island, and Vermont).

19. Although not listed by the sources used for Table 1, Croatia has applied a carbon tax to emissions by large stationary sources since 2007. The tax was revised to exclude sources covered by the EU ETS when Croatia joined in 2013. In addition, since July 2013, New Zealand has imposed a levy on imports, such as air conditioners, that contain synthetic GHGs. Bulk imports of synthetic GHGs are covered by the ETS. N.Z. ENVTL. Prot. AgEnCY, 2017 SYNTHETIC GREENHOUSE GAS LEVY REPORT (2017).

20. MtCO2e is equal to one million tCO2e.

21. These are weighted averages; the share for each jurisdiction is weighted by the emissions covered by the instrument in that jurisdiction. The average tax rates and allowance prices are calculated in the same way. 
$\left./ \mathrm{tCO}_{2} \mathrm{e}\right)$ is over $65 \%$ higher than the average ETS allowance price (USD $7.79 / \mathrm{tCO}_{2} \mathrm{e}$ ). Furthermore, the range of tax rates-from less than USD 1 to USD 140 -is much broader than the range of allowance prices-from less than USD 1 to USD 24.

Most of the jurisdictions with a carbon tax also have an ETS, usually covering different sources. Fourteen of the countries with a carbon tax participate in the EU ETS. ${ }^{22}$ Switzerland and Alberta, since 2018, also have both a tax and an ETS. ${ }^{23}$ As noted above, British Columbia has passed legislation to establish a baseline-and-credit ETS to complement its carbon tax, but this system currently is not operational. ${ }^{24}$ Japan and Mexico only have taxes. ${ }^{25}$ South Korea, as well as all sub-national jurisdictions other than Alberta and British Columbia, only have an ETS. ${ }^{26}$

22. Denmark, Estonia, Finland, France, Iceland, Ireland, Latvia, Liechtenstein, Norway, Poland, Portugal, Slovenia, Sweden, and the UK.

23. For Switzerland, see NARASSIMHAN ET AL., supra note 14, at 6-7. For Alberta, see Mascher, supra note 15, at 1013.

24. Mascher, supra note 15 , at 1015.

25. Mexico will start an ETS simulation in preparation of its pilot ETS launch in 2018. WORLD BANK, STATE AND TRENDS OF CARBON PRICING 201711 (2017).

26. INT'L CARBON ACTION P'SHIP (“ICAP”), EMISSIONS TRADING WORLDWIDE: STATUS REPORT 2018 (Johannes Ackva et al. eds., 2017), https://icapcarbonaction.com/en/publications [hereinafter, EMISSIONS TRADING WORLDWIDE]. 
Table 1. Information on Carbon Taxes and GHG Emissions Trading Systems in Operation at the end of $2015^{27}$

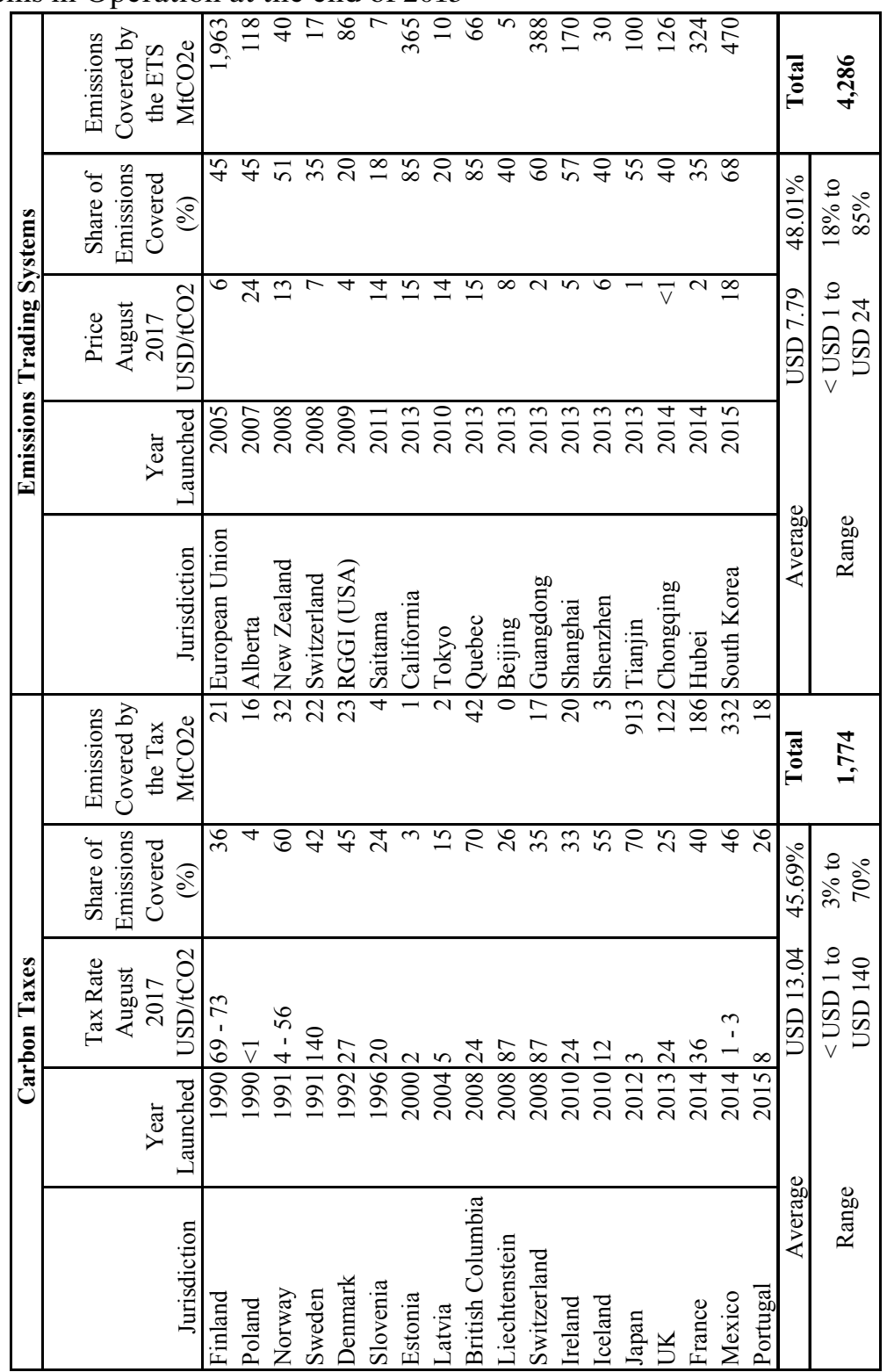

27. August 2017 prices are from WORLD BANK, supra note 25. Shares of emissions covered are from ClÉMENT MÉTIVIER ET AL., GLOBAl PANORAMA OF CARBON PRICES IN 20173 (2017), https://www.i4ce.org/publications-2/. For the EU and national jurisdictions, the emissions covered by the instrument are calculated from national emissions excluding LULUCF for 2016 reported by the UNFCCC Greenhouse Gas Inventory and the share of emissions covered by the 


\section{INSTRUMENT CHOICE AND DESIGN REFLECT REAL WORLD CONSIDERATIONS}

A variety of legal, political, and economic factors influence the choice and design of a jurisdiction's emissions policy. Constitutional authority or political considerations may limit the instrument choices. Members of the European Union and European Economic Area, for example, must join the EU ETS. ${ }^{28}$ In California, an ETS is more politically feasible because it only requires $50 \%$ of the legislature to approve, compared to two thirds of the legislature when it comes to taxes. ${ }^{29}$

Administrative feasibility also plays a role in a jurisdiction's choice of policy instruments. An ETS needs administrative infrastructure, including an allowance registry and allowance market supervision, while much of the infrastructure needed by a tax may already exist. An ETS also requires a competitive market for allowances, meaning a large number of participants with no dominant firms. Thus, a carbon tax may be better suited to a small jurisdiction or a developing country with limited administrative capacity. In some cases, a small jurisdiction can address these issues by joining an ETS covering multiple jurisdictions. Examples include Malta in the EU ETS and New Hampshire in the Regional Greenhouse Gas Initiative (RGGI).

instrument. Greenhouse Gas Inventory Data-Detailed Data by Party, UN FRAMEWORK CONVENTION ON ClimATE CHANGE, http://di.unfccc.int/detailed_data_by_party. For Alberta, British Columbia, and Quebec, total emissions for 2016 are from ENV'T. \& CliMATE CHANGE CANADA, NATIONAL INVENTORY REPORT 1990-2016-GREENHOUSE GAS SOURCES AND SINKS: EXECUTIVE SUMMARY 6 (2018). California total emissions for 2016 are from CAL AIR RESOURCES BD, CALIFORNIA GREENHOUSE GAS EMISSIONS FOR 2000-2016 (2018). For other GHG ETSs, the emissions covered are from the ICAP fact sheets for the respective systems in ICAP, supra note 26.

28. For a description of the legislative process governing the EU ETS and its implementation by member states, see EUROPEAN COMM'N, EU ETS HANDBOOK 9-11 (2015). Article 4 of Directive 2003/87/EC establishing the EU ETS, requires Member States to ensure that, from January 1, 2005, no installation undertakes any activity listed in Annex I of the Directive resulting in emissions specified in relation to that activity unless its operator holds a permit issued by a competent authority. Council Directive 87/EC, art. 4, 2003 O.J. (L275/32) (EC).

29. Guri Bang et al., California's Cap-and-Trade System: Diffusion and Lessons, 17 GLOBAL ENVTL. POL. 12, 26 (2017) ("California law requires a two-thirds legislative majority for the passage of new taxes, but 'regulatory fees' require only a simple majority."). Opponents challenged the ETS on the ground that the auction revenue was a tax, but this argument was unsuccessful. See, e.g., Cal. Chamber of Commerce v. State Air Res. Bd., 10 Cal. App. 5th 604, 649-50 (2017). Legislation to extend the ETS to 2030 was passed with a greater than two-thirds majority. Zeke Hausfather, Explainer: California's New 'Cap-and-Trade' Scheme to Cut Emissions, CARBONBRIEF (July 28, 2017, 1:35 PM), https://www.carbonbrief.org/explainercalifornias-new-cap-and-trade-scheme-to-cut-emissions. 
Conceptually, a carbon tax imposes a uniform tax per $\mathrm{tCO}_{2} \mathrm{e}$ emitted. In practice, a carbon tax is usually implemented as a series of taxes on various fossil fuels and emitting activities. ${ }^{30}$ Tax rates of USD 0.0259 per liter of diesel and USD 0.0202 per $\mathrm{m}^{3}$ of natural gas, for example, both correspond to a tax of USD $10 / \mathrm{tCO}_{2} \cdot{ }^{31}$ As in Finland and Sweden, the tax rate per $\mathrm{tCO}_{2} \mathrm{e}$ may differ by fuel and activity. Any tax on fossil fuels can be expressed in terms of a tax per $\mathrm{tCO}_{2} \mathrm{e}$ based on the carbon content of the fuel. ${ }^{32}$ This results in disagreements as to whether a tax is a carbon tax, including India's tax on coal, the UK's fossil fuel levy and climate change levy, and the taxes adopted by the Netherlands in $1996 .{ }^{33}$ A carbon tax raises additional implementation issues such as coverage, tax base, reporting requirements, and use of revenue. For example, emissions-intensive, trade-exposed (EITE) installations may be tax exempt or be eligible for refunds. Taxpayers typically are required to report the quantity of each fuel/activity subject to the tax and the tax payable, but not the associated emissions. ${ }^{34}$

Existing ETSs, with the exception of New Zealand, use one of two basic designs. The more common cap-and-trade design, such as the EU ETS, imposes a government-established cap on aggregate GHG emissions by specified sources, distributes tradable allowances (1 $\mathrm{tCO}_{2} \mathrm{e}$ each) approximately equal to the cap, and requires regulated emitters to submit allowances or other compliance units equal to their actual emissions. ${ }^{35}$ Under the baseline-and-credit design, such as the

30. WORLD BANK P'SHIP FOR MARKET READINESS, supra note 1 , at 10.

31. When fossil fuel is burned, virtually all of the carbon is emitted as $\mathrm{CO} 2$, so it is possible to express the tax on $\mathrm{CO} 2$ emissions as an equivalent tax on the carbon content of the fuel. See, e.g., 2016 Carbon Conversion Factors, CARBON FOOTPRINT (2016), https://www.carbonfootprint.com/2016_carbon_conversion_factors.html. The UK government's conversion factors for GHG reporting are $2.67620 \mathrm{~kg} \mathrm{CO} 2 \mathrm{e}$ per liter for $100 \%$ mineral diesel fuel and $2.02838 \mathrm{~kg} \mathrm{CO} 2 \mathrm{e}$ per cubic meter of natural gas ("Fuels" sheet). Thus, 373.6640 liters of diesel yield emissions of $1 \mathrm{tCO} 2 \mathrm{e}(1000$ (kg/ton)/2.67620 (kg/liter)). Id. Similarly, 493.00365 cubic meters of natural gas yield emissions of $1 \mathrm{tCO} 2 \mathrm{e}$. Id. A tax of USD 10/tCO2e therefore is equivalent to a tax of USD 0.02676 per liter of diesel fuel (USD 10/373.6640) and USD 0.020284 per cubic meter of natural gas). Id.

32. See OECD, TAXING ENERGy USE 2018 27-35 (2018) (expressing the effective tax rate due to all taxes on a fuel in different countries in terms of the tax per tCO2e).

33. The Dutch tax rates were USD 6.82/tCO2e for coal, USD 77.89 for light fuel oil, and USD 110.21 for natural gas thus creating an incentive to increase rather than reduce GHG emissions (use more coal rather than natural gas). See Érick Lachapelle, Energy Security and Climate Change Policy in the OECD: The Political Economy of Carbon-Energy Taxation 95, tbl.3.2.2 (2018) (unpublished Ph. D. dissertation, University of Toronto) (on file with journal).

34. See, e.g., B.C. Ministry of Finance, Self Assessors' Carbon Tax Return (Form FIN 112) (2018) (British Columbia carbon tax self-reporting return form).

35. The quantity of allowances distributed may be less than or greater than the cap. For a detailed description of the EU ETS, see EUROPEAN COMM'N, supra note 28. 
Tokyo ETS, the regulator sets an emissions limit for each participant. In practice, baseline-and-credit ETSs allocate free "allowances" to market participants: a participant whose actual emissions are below its limit receives tradable credits for the difference, while a participant whose emissions exceed its limit must submit purchased credits or other compliance units equal to its excess emissions.$^{36}$ In this design, the emissions limit may be absolute or be determined by the participant's output and an emissions intensity standard. ETSs of either type may differ in terms of other design features, including coverage, length of the compliance period, and price stability mechanisms.

Many ETSs allow participants to use credits issued for emission reductions outside the coverage of the trading program ("offset credits" or "offsets") for compliance. ${ }^{37}$ Those ETSs typically specify activities eligible to generate credits and limit the quantity of credits that may be used for compliance. Some ETSs restrict the use of offset credits to those generated in the same jurisdiction, while others allow the use of imported units. ${ }^{38}$ The Chinese pilots, for example, accept only offset credits generated by projects in China (Chinese Certified Emission Reductions, CCERs) ${ }^{39}$ and the EU ETS allows only credits issued by the Clean Development Mechanism or Joint Implementation mechanism subject to various qualitative and quantitative restrictions that have changed over time..$^{40}$

Once a jurisdiction selects an instrument, many design issues need to be resolved, especially the sources and emissions covered and the

36. In effect, the sum of the limits of all participants is the cap on aggregate emissions. Changes to the participant population automatically adjust the cap on aggregate emissions. In contrast, in a "cap-and-trade" system, the cap usually is not adjusted for changes to the number of sources.

37. See Erik Haites, Experience with Linking Greenhouse Gas Emissions Trading Systems, 5 WIRES ENERGY ENV'T 246, 247 (2016) ("Two ETS are linked if a participant in one system can use an allowance or a credit (compliance instrument) issued by either system for compliance.").

38. Between 2008 and 2014, the New Zealand ETS allowed unlimited use of specified imported units. The Swiss ETS and EU ETS accepted imported units subject to qualitative and quantitative restrictions between 2008 and 2012. See id. at tbls.1-3 (collecting data on the use of imported credits by the New Zealand, Swiss, and EU ETSs). The Chinese pilot trading programs only accept offset credits (CCERs) awarded for eligible emission reduction projects in China. Dimitri De BoER ET AL., CHINA CARbon Forum, THE 2017 CHINA CARbon PRICING SurVEY 4 n. 4 (2017).

39. Deng et al., supra note 11 , at 992 .

40. The Clean Development Mechanism and Joint Implementation are mechanisms established by the Kyoto Protocol that award internationally recognized credits for emission reductions achieved by projects in respectively developing and developed countries. For rules on the use of such credits by participants in the EU ETS, see EUROPEAN COMM'N, supra note 28, at 96. 
treatment of emissions-intensive, trade-exposed (EITE) installations that face competition from firms in jurisdictions with weaker (or no) policies to limit GHG emissions. All instruments exclude some emissions for administrative reasons-emissions that are difficult to measure, such as forests and agriculture, ${ }^{41}$ and small emissions by numerous sources, such as emissions from landfills. ${ }^{42}$ Emissions may also be excluded for policy reasons, most often those of the agricultural sector. In practice, the share of a jurisdiction's emissions covered ranges from $18 \%$ to $85 \%$ for ETSs and from $3 \%$ to $70 \%$ for taxes. ${ }^{43}$

Imposing a carbon tax or ETS compliance obligation on an EITE firm can have adverse economic and environmental consequences. The instrument imposes a cost on the firm and makes it less competitive relative to similar firms in jurisdictions with weaker GHG emission limitation policies. Production and associated emissions may shift to the jurisdiction with the weaker policy ("leakage"), reducing the anticipated environmental benefits and imposing economic costs on the jurisdiction implementing the more stringent policy. ${ }^{44}$ Thus, virtually all instruments have provisions to protect EITE firms. In the case of taxes, provisions include exemptions, differential tax rates, rebates, and other support. ${ }^{45}$ With an ETS, protective provisions include free allowances (emissions limit in a baseline and credit system) and rebates. ${ }^{46}$

Furthermore, almost all ETSs include some price stability provisions to alleviate the uncertainty of emitters' compliance cost. ${ }^{47}$

41. The New Zealand ETS is an exception. It includes forests and requires emissions reporting by agriculture. N.Z. MINISTRY FOR THE ENV'T, NO. ME 1129, THE NEW ZEALAND EMISSIONS TRADING SCHEME EVALUATION 20169 tbl.2 (2016).

42. Some emissions can be included indirectly; regulating the emissions of electricity generators and residential fuel suppliers, for example, covers virtually all household emissions. Partial coverage of excluded sources is also possible by allowing entities to earn offset credits for verified emission reductions.

43. See supra Table 1.

44. For a review, see Frédéric Brangar \& Philippe Quirion, Climate Policy and the "Carbon Haven" Effect, 5 WIREs CLIMATE CHANGE 53 (2014) ("Most ex ante modeling studies conclude to leakage rates in the range of 5-20\% (if no option to mitigate leakage is implemented), whereas ex post econometric studies have not revealed statistically significant evidence of leakage.").

45. WORLD BANK P'SHIP FOR MARKET READINESS, supra note 1 , at 18.

46. See EUROPEAN COMM'N, supra note 28, at 60 (outlining the provisions of the EU ETS to address leakage and listing several studies that attempt to estimate leakage for vulnerable sectors covered by the ETS).

47. In a cap-and-trade ETS, for example, emitters must submit allowances equal to their actual emissions to achieve compliance. An emitter's actual emissions during a period depend in part on its output which is uncertain. The cost of the allowances needed depends on the quantity received free and the quantities purchased at auction and at market prices with both auction and 
Typically, these provisions include the ability to use offset credits from outside the cap for compliance and the sale of additional allowances at specified levels up to a price ceiling. ${ }^{48}$ In a few ETSs, such as Alberta and New Zealand, the price ceiling takes the form of a fixed price compliance option. Some ETSs also set a minimum price. A minimum price and a price ceiling together establish a "price collar".

Implementing a tax or ETS raises issues on how to treat industries whose prices are regulated, such as taxis and electric utilities. In the case of transportation fuels, the cost of the tax or ETS allowances increases the price of fuel, and the higher fuel price typically leads to a fare increase. Electric utilities can reduce emissions by adjusting the operations of generating units that use different fuels. That makes it difficult to calculate the actual cost of a tax or ETS to a utility. ${ }^{49}$ During the early phases of the EU ETS, provision of free allowances to electric utilities led to higher electricity prices and large profits for utilities. ${ }^{50}$ To limit electricity price increases, California issues free allowances to utilities but requires that they be sold at the quarterly auctions. The revenue received is credited toward the cost of purchasing the allowances needed for compliance when the regulator calculates approved electricity prices.

In practice, then, the instrument designs are more complex than the theoretical models with the result that it is sometimes difficult to decide whether an instrument is a carbon tax or an ETS. ${ }^{51}$ For example, RGGI has a minimum price, and at times between 2009 and 2013, the auction price was equal to the minimum price with some allowances not sold. ${ }^{52}$ During that time, the ETS was in effect a tax with the tax rate equal to the minimum price. Switzerland implemented a carbon

market prices being uncertain. See generally id.

48. Easwaran Narassimhan et al., Carbon Pricing in Practice: A Review of Existing Emissions Trading Systems, 18 CLIMATE POL'Y 967, 975-81 (2018).

49. William ACWORTH ET AL., InT'L CARbON ACTION P'SHIP, EMISSIONS TRADING AND ELECTRICITY SECTOR REGULATION 11 (2018).

50. SANDER DE BRUYN ET Al., CE Delft, CAlculation of Additional Profits of SECTORS AND FIRMS FROM THE EU ETS 8 (2016).

51. See Lachapelle, supra note 33, at 68 ("[T]he main difference between the two instruments lies in setting the price versus quantity of emissions... Taxes are 'price-based' instruments, meaning that the price of carbon is fixed, and the quantity of emissions adjusts according to decisions made by private actors in the market ... Conversely, emissions trading is 'quantity-based,' meaning that the quantity of emissions is capped by the government.").

52. Jonathan L. Ramseur, Cong. Res. Serv., The Regional Greenhouse Gas INITIATIVE: LESSONS LEARNED AND ISSUES FOR CONGRESS 10 (2017) ("Some of the offered allowances were not sold and were subsequently retired.”). 
tax but allowed trading to achieve compliance..$^{53}$ The trading option was widely used so the tax effectively served as the non-compliance penalty for the trading system..$^{54}$ Consistent with other studies, this paper treats both as ETSs: ${ }^{55}$ RGGI because the floor price prevailed only for a limited period, and Switzerland because the overwhelming compliance option was trading.

\section{EVALUATION CRITERIA}

The main aim of this paper is to assess the performance of carbon taxes and GHG ETSs as currently implemented. That requires evaluation criteria. Drawing on criteria suggested by Goldblatt ${ }^{56}$ as the basis for choosing between a tax and ETS for South Africa, the following evaluation criteria are proposed:

Principal criteria: Environmental effectiveness (reduction of actual emissions); Cost-effectiveness (low marginal abatement cost). Secondary criteria: Economic efficiency (low price low volatility, price signal commitment into the future to support investment decisions, and harmonization of marginal costs across jurisdictions); Public finance (revenue raised, and potential cross-jurisdiction revenue flows); Administrative issues (institutional capacity, administrative costs, difficulty of making adjustments to rules, and minimization of corruption).

53. ENVTl. Def. Fund Et Al., Switzerland: An EMISSIONS Trading CASE STUdy 7 (2015) ("Firms covered by the levy had two choices: (1) pay the CO2 levy, or (2) voluntarily set a verified absolute emissions target and associated allowance allocation and participate in the Swiss ETS, which exempted them from the levy.").

54. Id. at 6 ("[T]he penalty for companies that failed to achieve their Swiss ETS targets was retroactive payment of the carbon levy (plus interest) for each ton of $\mathrm{CO} 2$ emitted since the company's exemption.").

55. See, e.g., ICAP, supra note 26, at 52 (listing both RGGI and Switzerland as ETSs); see also MÉTIVIER ET AL., supra note 27, at 3 (listing both RGGI and Switzerland as ETSs); WORLD BANK, supra note 25, at 12 (listing RGGI as an ETS and Switzerland as having both an ETS and a carbon tax and demonstrating that other studies also treat them as ETSs).

56. The Goldblatt criteria include the public policy criteria of economic efficiency, environmental effectiveness, public finance considerations, welfare impacts, administrative complexity, and relationship to global GHG reduction; they also include sub-criteria of price volatility, impact on investment, certainty of results, coverage and exemptions, ability to monitor and enforce, and ability to raise revenue cross-country revenue flows tax incidence and interactions, distribution of costs and benefits across income groups, economic sectors and generations, transparency of costs and benefits, institutional capacity costs of administration minimization of corruption, level of emissions leakage, ability to harmonize global carbon pricing efforts. Michael Goldblatt, Comparison of Emissions Trading and Carbon Taxation in South Africa, 10 Climate Pol'y 511, 516 (2010). 
A jurisdiction implementing a carbon tax or GHG ETS may also be concerned about, inter alia, employment, income distribution, regional impacts, economic growth, and technology development. These are important issues that can be addressed through the design of the instrument and use of the revenue generated. In our judgment, these factors are not issues inherent to a tax or ETS so we do not use them to assess the performance of the instruments.

\section{A. Environmental effectiveness}

Since the overriding purpose of a carbon tax or GHG ETS is to reduce GHG emissions, the primary criterion is environmental effectiveness. ${ }^{57}$ Environmental effectiveness has two dimensions - the share of the jurisdiction's GHG emissions covered by the instrument and the net reduction in aggregate emissions covered by the instrument.

All else equal, an instrument that covers a larger share of a jurisdiction's emissions should lead to larger emission reductions and so be more effective. The share of the jurisdiction's emissions covered varies widely for existing carbon taxes and ETSs as shown in Table 1, but the overall average is only slightly higher $(48.1 \%)$ for ETSs than taxes $(45.5 \%) .{ }^{58}$ Any difference in environmental effectiveness therefore depends primarily on the reduction in the aggregate emissions covered by the instruments.

Measuring emission reductions achieved by a carbon tax or ETS and comparing reductions across jurisdictions raise several issues. A tax or ETS has both price effects and revenue effects. As the cost of emitting GHGs rises, consumers opt to purchase less GHG-intensive goods and services. The revenue collected reduces income spent on GHG-emitting activities, which lowers emissions, but how the revenue is used could further raise or lower emissions. These price and revenue effects impact not only the jurisdiction implementing the policy, but also other jurisdictions with which it has direct or indirect economic relationships.

57. Some jurisdictions may have implemented an instrument, more likely a tax than an ETS, as a means of raising revenue. Ireland's carbon tax, for example, was introduced to help meet revenue raising and expenditure reduction targets established as conditions for international financial support to help the country's address its fiscal crisis. See Frank Convery, Louise Dunne \& Deirdre Joyce, Carbon Tax in the Context of the Fiscal Crisis, 8 CyPRUs ECON. POL'Y REV. 135, 135-36 (2014).

58. An ETS that allows the use of offset credits for compliance extends the price signal to sources outside the cap that are eligible to generate credits. 
Since these instruments put a price on GHG emissions in the implementing jurisdiction, the price effects are the key to their performance. The first issue is whether to include the revenue effects when assessing their performance. Our choice is to exclude the revenue effects for conceptual and practical reasons. Conceptually, use of tax revenue involves distinct policy choices not necessarily related to emissions policy. While the proposed use of revenue may be important in building support for a tax or ETS when it is introduced, actual use of the revenue changes over time and varies widely across jurisdictions.

The practical reason is that there are several revenue effects that are difficult to estimate and that have different impacts on emissions. Revenue collected reduces spending on GHG-emitting goods and services, thus lowering emissions. However, some of the revenue redistributed to firms and households is spent on GHG-emitting goods and services, thus raising emissions, whereas revenue used to fund mitigation measures lowers emissions. ${ }^{59}$ As a result, the effect of those expenditures would be double counted, both as lower emissions due to the instrument and as funded reductions. The fact that these changes in emissions are spread across multiple jurisdictions increases the practical difficulties of trying to estimate the revenue effects.

Focusing on the emission reductions due to the price effects raises the issue of the appropriate geographic scope. Our choice is to focus on emission reductions in the implementing jurisdiction. Again, there are conceptual and practical reasons for this choice. The conceptual reason is that the instrument is implemented by a jurisdiction for the purpose of reducing its emissions; thus, that is the relevant measure of performance. However, the climate change impact depends on changes to global emissions, which may be lower than the domestic reductions due to inter-jurisdictional leakage.

The practical reason for focusing on domestic emission reductions is that leakage is very difficult to estimate and is likely to be small in practice. Implementation of a carbon pricing instrument can lead to higher emissions by other sources via several different channels. ${ }^{60}$ Such

59. See Jeremy Carl \& David Fedor, Tracking Global Carbon Revenues: A Survey of Carbon Taxes Versus Cap-and-Trade in the Real World, 96 ENERGY POL'Y 50, 52-53 (2016). Revenue collected in 2013 totaled USD 21.7 billion for taxes and USD 6.57 billion for ETSs. Id. at 51-52. Redistributed shares were reported as tax cuts and rebates and were used to fund adaptation and emission reduction measures. $I d$. at 65 . The shares reported for the use of tax revenue do not sum to $100 . I d$. at 52 .

60. See Zengkai Zhang \& Zhong Xiang Zhang, Intermediate Input Linkage and Carbon Leakage 1, 3 n.1 (Fondazione Eni Enrico Mattei, Working Paper No. 062, 2016) (identifying the competitiveness channel, fossil fuel channel, terms-of-trade effect, abatement resource effect, 
inter-source leakage is difficult to estimate ${ }^{61}{ }^{2}$ Ex ante model estimates range from $5 \%$ to $20 \%$, but the modelled instruments often lack the specific provisions implemented to minimize leakage. Ex post econometric studies for Europe find no evidence of leakage. ${ }^{62}$ Instrument designs try to limit the leakage by reducing the economic cost to EITE sources through exemptions, rebates, free allowances or other measures. ${ }^{63}$

The challenge, then, is to measure the changes in domestic emissions due to the price effects of the tax or ETS. The instrument reduces emissions from what they would have been. Estimating what emissions would have been and then calculating the reduction achieved by the instrument is complex and speculative. Business-as-usual emissions cannot be observed, only estimated. ${ }^{64}$ Ex post estimates based on actual levels of economic activity, weather, energy prices and other factors affecting emissions are likely to be more accurate, but they are still uncertain..$^{65}$

We adopt a more practical, but more stringent, measure of performance: the change in actual emissions subject to the instrument. Data on actual emissions are verified for compliance purposes and are reliable and publicly available for most of the ETSs. We have not found a single jurisdiction that regularly tracks emissions subject to its carbon

technology channel, scale channel, and intertemporal channel).

61. See Brangar \& Quirion, supra note 44, at 58 ("A recent comparative study of 12 different models gave the most robust results so far. The estimate of leakage is 5-19\% ...."); see also Bruce Arnold, International Trade and Carbon Leakage 2 (Cong. Budget Office, Working Paper No. 2013-08, 2013) (stating that "[e]stimates of leakage ... range from 1 percent to 23 percent"); Zhong Xiang Zhang, Competitiveness and Leakage Concerns and Border Carbon Adjustments 9 (Fondazione Eni Enrico Mattei, Working Paper No. 731, 2012) (citing "estimates of carbon leakages ... in the range of 5-20\%").

62. See Brangar \& Quirion, supra note 44, at 60 ("The studies focusing on the EU ETS, the largest carbon pricing experiment so far, have not revealed any evidence of carbon leakage... .").

63. See generally Justin Caron et al., Leakage from Sub-National Climate Policy: The Case of California's Cap-and-Trade Program, 36 ENERGY J. 25 (2015); see also Zhang, supra note 61, 19-21; Elisa Lanzi et al., Addressing Competitiveness and Carbon Leakage Impacts Arising from Multiple Carbon Markets: A Modelling Assessment 27 (OECD Publ'g, Working Paper No. 58, 2013); EUROPEAN COMM'N, supra note 28, at 36.

64. See A. Denny Ellerman \& Barbara K. Buchner, Over-Allocation or Abatement? A Preliminary Analysis of the EU ETS Based on the 2005-06 Emissions Data 7 (Fondazione Eni Enrico Mattei, Working Paper No. 139, 2006) ("Given uncertainty, the only way to overcome ... over- and under-allocation would be to adjust allowances ex post ....").

65. Id. ("To the extent that economic activity, weather or any other factor affecting emissions deviates from what is expected, counterfactual emissions will be higher or lower than expected and any given cap will be more or less constraining with consequent effects on the positions of all the components.") 
tax. Our approach to estimating taxed emissions is discun Section IV. Because reduction from what emissions would have been may not be sufficient to lower actual emissions, requiring a reduction in actual emissions is a more stringent criterion. We believe reduction of actual emissions is an appropriate criterion given that most of the jurisdictions that have implemented a tax or ETS have a GHG target expressed as a reduction from a historic level. ${ }^{66}$

The use of external offset credits for compliance leads to higher actual emissions and hence worse performance for some ETSs. This applies only to ETSs, since none of the taxes being assessed allows the use of offsets for compliance. ${ }^{67}$ Actual emissions are not adjusted for the use of external offset credits because they were used mainly between 2011 and 2014, with negligible use during earlier and later years. ${ }^{68}$ This means they have negligible impact on the actual emissions during the years used to calculate the rates of change in emissions.$^{69}$ If there is an impact, it is to make our standard slightly more stringent.

In summary, the environmental performance of an instrument is measured as the change in actual emissions by sources subject to the instrument. Emissions changes due to the collection and use of the revenue are excluded. Emissions changes due to the use of offsets and leakage are likewise excluded. This is a more stringent measure of

66. For example, British Columbia has a target of a $33 \%$ reduction from 2007 emissions by 2020, and Quebec has a target of a 20\% reduction from 1990 GHG levels by 2020. See CARBON Disclosure PRoJeCt (“CDP”), GLOBAL StATES AND REGIONS ANNUAL Disclosure, 2017 UPDATE 5-6 (2017). The EU target is a 14\% reduction from 2005 emissions by 2020 with the ETS achieving a $21 \%$ reduction and non-ETS sectors a $10 \%$ reduction. See EUROPEAN COMM'N, supra note 28 , at 12 . Tokyo has a target of a $25 \%$ reduction from 2000 GHG levels by 2020 , and RGGI states have a regional target of a more than $50 \%$ reduction of $\mathrm{CO} 2$ emissions from electricity generation from 2005 levels by 2020. See Japan Tokyo Cap-and Trade Program and USA Regional Greenhouse Gas Initiative (RGGI) Factsheets, ICAP, https://icapcarbonaction.com/ en/ets-map?etsid=50. The reduction target for the tax or ETS may differ from the overall target for the jurisdiction but since these instruments cover about half of the jurisdiction's total emissions on average, an overall target that requires a reduction in actual emissions likely requires a reduction in emissions subject to the instrument as well.

67. But see Climate Action Reserve, introduction to CARbon Markets in MEXICO 3 (2015). The Mexican carbon tax legislation allows entities to use CERs generated by CDM projects in Mexico to reduce their overall tax bill by an amount equivalent to the market value of the CERs at the time the tax is paid. $I d$. It appears that these rules and valuation criteria have yet to be fully developed. $I d$.

68. Haites, supra note 37, at 252-54.

69. See Randall Spalding-Fecher et Al., CDM Policy Dialogue, Assessing the IMPACT OF THE CLEAN DEVELOPMENT MECHANISM 37 (2012) (concluding that "[t]he CDM [an offset credit] in its current form has negligible sustainable development benefits"); see also Peter Erickson et al., Net Climate Change Mitigation of the Clean Development Mechanism, 72 ENERGY POL'Y 147 (2014) (stating that an assessment of the performance of the instruments on a global basis would need to address the additionality of the offset credits). 
performance than a reduction from what emissions would have been, but it is consistent with the targets of most of the jurisdictions that implemented the instruments and relies upon on much higher quality data.

The performance of instruments that cover different quantities of emissions and that have been in effect for different periods of time is compared on the basis of the compound annual rate of change of actual emissions. The use of the annual rate of change also enables instruments whose data are reported for fiscal years to be compared with those that report on a calendar year basis. The use of data on actual emissions means that the base for calculating the annual rate of change is the actual emissions for the first year or first compliance period the instrument was in effect and, consequently, that any reductions achieved during the first year or period are excluded. ${ }^{70}$ Again, this yields a conservative estimate of performance.

\section{B. Cost effectiveness}

Cost effectiveness focuses on achieving the emission reduction target at minimum cost. Minimizing the cost of reducing GHG emissions benefits society by freeing up resources for other priorities. Indeed, the main motivation for implementing carbon taxes and GHG ETSs is that they can reduce emissions at lower cost to society than other forms of regulation. ${ }^{71}$

The marginal abatement cost for an emitter is the tax rate (USD $\left./ \mathrm{tCO}_{2} \mathrm{e}\right)$, in the case of a carbon tax, and the price of an allowance, in the case of an ETS. ${ }^{72}$ The tax rate is set by the government, while the allowance price is determined by the market. Jurisdictions set the tax rate to achieve an emissions reduction target, meet a revenue target, reflect the social cost of $\mathrm{CO}_{2}$ emissions, or match compliance costs in other jurisdictions. ${ }^{73}$ The allowance price reflects the emissions target and other provisions of the ETS design.

In practice, both tax rates and allowance prices span wide ranges. As shown in Table 1, tax rates range from less than USD $1 / \mathrm{tCO}_{2} \mathrm{e}$ to USD 140/tCO $\mathrm{tC}_{2} \mathrm{e}$, while ETS prices range from less than USD 1/tCO $\mathrm{CO}_{2} \mathrm{e}$

70. The Japanese carbon tax and Irish solid fuel carbon tax took effect mid-year. The actual emissions for the first full year are used as the base of the calculation of rate of emission reduction.

71. Pollitt, supra note 1, at 3; Baranzini et al., supra note 2, at 3-6.

72. Pollitt, supra note 1 , at 7-8.

73. WORLD BANK P'SHIP FOR MARKET READINESS, supra note 1, at 26 ("Carbon taxes can also be designed to generate a number of... important benefits, such as raising revenue, internalizing the social costs of emissions, and increasing the efficiency of the tax system."). 
to USD 24/tCO ${ }_{2}$ e. In 2017 the average tax rate (USD 13.04) was over $65 \%$ higher than the average ETS allowance price (USD 7.79).

Some analyses compare tax rates and allowance prices to estimates of the economic value of a one $\mathrm{tCO}_{2} \mathrm{e}$ emission reduction (the social cost of carbon) over time. ${ }^{74}$ This cost-benefit test is difficult to implement due to the wide range of the estimated values of the social cost of carbon. ${ }^{75}$ In addition, using the social cost of carbon may be inappropriate because it incorporates numerous impacts of GHG emissions that are very difficult to estimate and applies a marginal value to a non-marginal situation, the need to completely eliminate anthropogenic GHG emissions to stabilize atmospheric concentrations. $^{76}$

Since most of the jurisdictions that have implemented a carbon tax or GHG ETS have a target that requires a reduction of actual emissions, the cost-effectiveness goal of achieving that target at the lowest cost is more appropriate than the cost-benefit test that compares the tax rate or allowance price with the social cost of carbon. Even if a specific value of the social cost of carbon could be agreed upon, the emission reduction that would be achieved with a tax rate or allowance price equal to that value is not known for most jurisdictions and is unlikely to coincide with its established target.

\section{Economic efficiency}

Economic efficiency has several dimensions in addition to cost effectiveness, including price stability, a credible price signal, and harmonization across jurisdictions. ${ }^{77}$ The vast majority of mitigation

74. See Lawrence H. Goulder et al., China's National Carbon Dioxide Emission Trading System: An Introduction, 6 ECON. ENERGY \& ENVTL. POL'Y 1, 11-12 (2017) ("The social cost of carbon (SCC) represents the marginal climate benefit, and in a well-functioning ETS the allowance price indicates marginal abatement costs.").

75. See, e.g., William D. Nordhaus, Revisiting the Social Cost of Carbon, 114 PROCEEDINGS NAT'L ACAD. SCI. 1518, 1520-21 (2017); Nicholas Stern, The ECONOMics of Climate CHANGE: The STERn ReviEW 62 (2006); Stephen Smith \& Nils Axel Braathen, Monetary Carbon Values in Policy Appraisal: An Overview of Current Practice and Key Issues 10-15 (OECD Publ'g, Working Paper No. 92, 2015) (discussing how estimating the social cost of carbon is very complex and the results are very sensitive to the discount rate used, with several authors discussing methodological issues and values used by different countries); Maximilian Auffhammer, Quantifying Economic Damages from Climate Change, 32 J. ECON. PERSPS. 33 (2018) (describing the multiple approaches to estimating the social cost of carbon).

76. See Morgan et al., Rethinking the Social Cost of Carbon Dioxide, 33 IssuES IN SCI. \& TECH. 4 (2017) (asserting that "false precision from IAMs is being used in the generation of quantitative 'answers' that have come to serve as an inappropriate foundation for public policies").

77. See World Bank CARbon Pricing LeAdership CoAl., Report of the High- 
actions involve capital investments; price stability and a credible price signal facilitate those investment decisions. Harmonization across jurisdictions improves global economic efficiency. An ETS is countercyclical-during a recession output declines, emissions fall, allowance prices drop, and compliance costs are reduced with the opposite effects during an economic boom - while the tax rate remains constant or rises. $^{78}$

Price stability (low volatility) allows market participants to better evaluate potential mitigation options. ${ }^{79} \mathrm{~A}$ tax is more stable than allowance prices, but changes to the tax rate tend to be unpredictable. ${ }^{80}$ Many ETSs include provisions to enhance price stability such as sale of additional allowances when the price is high, access to offset credits, and a minimum price. Larger ETSs tend to have options and futures contracts that enable sources to obtain allowances at an agreed price at a future date, thus reducing price uncertainty. ${ }^{81}$ Comparable options and contracts do not exist for taxes.

A commitment that signals future prices also facilitates mitigation investment decisions. ${ }^{82}$ The price signal should cover a period during which most investments are repaid - at least five years into the future. When a new carbon tax is implemented, annual or biannual tax rate increases are often announced three to five years into the future. ${ }^{83}$ The frequency of tax rate changes varies widely across jurisdictions, but across all the taxes analyzed, about $40 \%$ of the years have no increase

LEVEL COMMISSION ON CARBON PRICES 21-24 (2017) (discussing characteristics of "dynamic and adaptive climate policy designs," including the efficiency of carbon-price signals and international cooperation).

78. See Pollitt, supra note 1 , at 11 (contrasting carbon trading schemes with "[f]ixed tax rates [which] become more burdensome and hence difficult to defend in times of recession").

79. If future allowance or credit prices are uncertain, the value of future emission reductions is uncertain. Greater price volatility means greater uncertainty. Greater uncertainty favors investments with shorter payback periods.

80. See infra Section IV.C. For a discussion of the possible mechanisms to reduce the political uncertainty associated with taxes, see WORLD BANK P'SHIP FOR MARKET READINESS, supra note 1 , at chs.6, 7.

81. See EUROPEAN COMM'N, supra note 28, at 71 (describing futures and options trades). The ICE exchange, for example, offers Futures Options for the allowances of the EU ETS (EUAs). See EUA Futures Options Contract, InTERCONTINENTAL EXCHANGE, https:/www.theice.com/products/196/EUA-Futures-Options (last visited Oct. 25, 2018).

82. See Dijkgraaf et al., On the Effectiveness of Feed-In Tariffs in the Development of Solar Photovoltaics, 39 ENERGY J. 81, 94 (2018) (finding in their analysis of the effectiveness of feed-intariffs for solar photovoltaics in Europe that the maximum effect can be as much as seven times larger with a high tariff and a long contract duration in combination with a consistent policy).

83. See generally WORLD BANK P'SHIP FOR MARKET READINESS, supra note 1, at apps. (showing that upon introduction, tax rates were specified for three years by France and the UK and for five years by British Columbia and Japan). 
in the tax rate.$^{84}$ Practices relating to changes in tax rates are discussed further in Section IV.C. ETSs tend to have longer (five to eight years) and stronger commitments (regulations and legislation) to future caps and price stability provisions. ${ }^{85}$

Global economic efficiency is improved if all sources in all jurisdictions face the same marginal abatement cost. In principle, carbon taxes can be harmonized across jurisdictions, but international coordination of a tax is very complex and has never been attempted. ${ }^{86}$ Linking ETSs to allow participants to use allowances from any of the linked ETS for compliance could narrow allowance price differences. Such linking is common, but current ETSs limit the quantity of imported allowances. Thus, the price differences across ETSs are narrowed but not eliminated and the potential savings are only partially realized. ${ }^{87}$

\section{Public finance}

Both taxes and ETSs (auctioned allowances) raise revenue. The revenue can be used for a mix of economic stimulus (reduce existing distortionary taxes), equity (fair distribution of the costs of reducing GHG emissions), environmental goals (funding GHG reductions or adaptation measures), and other purposes. Although we exclude the emissions impacts of revenue collection and use, the amount of revenue collected and its use for economic and environmental purposes can be an important consideration in building and sustaining support for a carbon tax or GHG ETS.

Carbon taxes tend to raise more revenue than ETSs for two reasons. A carbon tax imposes the tax on all designated emissions, while many ETSs distribute some allowances for free. Furthermore, tax

84. Analysis of the tax rate data in infra Annex I shows that in $42 \%$ of the years the tax rate was the same as the previous year.

85. See generally Jessika Luth Richter \& Lizzie Chambers, Reflections and Outlook for the New Zealand ETS, 10 POL'Y Q. 57 (2014) (concluding that regulatory uncertainty meant there was no incentive to invest in mitigation actions thus contributing to the ineffectiveness of the New Zealand ETS).

86. It is the effective tax that must be harmonized. In addition to the carbon tax, the effective tax also depends on other taxes such as fuel taxes, Value Added Tax (VAT), and sales taxes on energy, so the burden of all of those taxes on each category of emitters needs to be harmonized. Then there are practical issues of harmonizing taxes denominated in different currencies and coordinating implementation of tax changes across jurisdictions. See Pollitt, supra note 1, at 10.

87. RGGI consists of nine linked state systems but they use a common allowance, so there are no restrictions on transfers among states. Similarly, California and Quebec use allowances that are indistinguishable to users with no restrictions on interjurisdictional transfers. Haites, supra note 37 , at 257 . 
rates tend to be higher than allowance prices, thereby raising more revenue. In 2013, carbon taxes collected USD 21.7 billion in revenue while ETSs generated USD 6.57 billion. ${ }^{88}$ By 2017, the total revenue had increased to USD 32 billion: USD 21 billion from taxes and USD 11 billion by ETSs. ${ }^{89}$

In practice, the revenue collected from carbon taxes and ETSs is used differently. In 2013, 70\% of the ETS revenue was used to subsidize "green" spending on energy efficiency, renewable energy, and adaptation measures; $21 \%$ went to general revenue; and $9 \%$ was used to fund corporate and individual tax cuts or direct rebates. ${ }^{90}$ In the case of carbon taxes, $15 \%$ of the revenue was used to support green spending, $28 \%$ went to general revenue and $44 \%$ was used for tax cuts and rebates. ${ }^{91}$ These percentages vary widely across jurisdictions for both taxes and ETSs.

A considerable body of literature is devoted to the potential economic benefits of revenue recycling-using carbon tax or ETS auction revenue to reduce existing distortionary taxes. ${ }^{92}$ Based on the 2013 data, as much as $85 \%$ of the tax revenue and up to $30 \%$ of the ETS revenue might be used to reduce existing distortionary taxes. These figures combine the percentages of revenue that went to general revenue (and so could offset revenue lost due to cuts in other taxes) and to tax cuts and rebates.

Many of the national jurisdictions that have implemented a carbon tax and a GHG ETS were parties to the Kyoto Protocol for the 200812 commitment period, ${ }^{93}$ including the members of the EU ETS, Japan,

88. Carl \& Fedor, supra note 59, at 52-53.

89. Clément Métivier et Al., InSt. FOR Climate ECON., Global Carbon Account 2018 1, 4 (2018), https://www.i4ce.org/publications-2/; see also Smith \& Braathen, supra note 75, at 1016.

90. Carl \& Fedor, supra note 59, at 52-53.

91. Id. at 53. Rebates are more likely to go to entities subject to the tax, such as EITE firms, while tax cuts are more likely to go to individuals adversely affected by the carbon tax. The percentages for the use of carbon tax revenue do not sum to 100 . If the shares are recalculated to sum to 100 , they are $17 \%$ green spending, $32 \%$ general revenue, and $51 \%$ tax cuts and rebates.

92. See Cameron Hepburn, Regulation by Prices, Quantities or Both: A Review of Instrument Choice, 22 OXFORD REV. ECON. POL'y 226, 236-37 (2006) (reviewing the literature on the economic benefits of revenue recycling).

93. The Kyoto Protocol to the United Nations Framework Convention on Climate Change, which entered into force in 2005, committed parties listed in Annex B (developed countries and countries with economies in transition) to limit their 2008-12 greenhouse gas emissions. It established three international emissions trading mechanisms that the parties could use to help them meet their commitments - the clean development mechanism (CDM, article 12), joint implementation (JI, article 6), and international emissions trading (IET, article 17). The CDM enabled approved emission projects in developing countries to earn credits (CERs) that could be 
New Zealand, and Switzerland. The Kyoto Protocol established three international market mechanisms-the clean development mechanism, joint implementation, and international emissions trading. The units traded using these mechanisms-CERs, ERUs, and AAUs respectively - were accepted, with some qualitative and quantitative restrictions, for compliance by the national ETSs of these countries. ${ }^{94}$ CER purchases by ETS participants helped fund emission reduction measures in developing countries. ${ }^{95}$

All international climate agreements have called, and continue to call, for resource transfers from developed to developing countries. ${ }^{96}$ With an ETS such transfers can occur via trade in allowances and offset credits as well as through government budgets. With a carbon tax international resource transfers must flow through government budgets.

\section{E. Administrative issues}

An ETS requires a more complex and costlier administrative structure than a carbon tax. Although most jurisdictions already collect taxes on fossil fuels, adding a carbon tax may involve changes to the monitoring, reporting, and verification (MRV) system and to compliance enforcement. The administrative complexity and cost rise if the scope of the carbon tax extends beyond fossil fuels already taxed.

An ETS, on the other hand, creates new administrative requirements including: an MRV system; institutions to distribute allowances, enforce compliance, and monitor the allowance market; and a computer registry to track allowance holdings. Jurisdictions that have implemented an ETS, such as the EU and California, have offered

sold to Annex B parties. JI and IET enabled credits (ERUs) and allowances (AAUs) respectively to be traded among Annex B parties. In 2012, the Doha amendment to the Kyoto Protocol that specifies 2013-20 commitments for Annex B parties was adopted. The Amendment has not yet entered into force. See Kyoto Protocol to the United Nations Framework Convention on Climate Change, Dec. 10, 1997, U.N. Doc FCCC/CP/1997/7/Add.1, 37 I.L.M. 22 (1998); What is the Kyoto Protocol?, UN FRAMEWORK CONVENTION ON CLIMATE CHANGE, https://unfccc.int/processand-meetings/the-kyoto-protocol/what-is-the-kyoto-protocol (last visited Nov. 3, 2018).

94. Haites, supra note 37 , at 251-55.

95. See CDM Pipeline Overview, UNEP DTU PARTNERSHIP, www.cdmpipeline.org (last visited Oct. 4, 2018) (showing that the clean development mechanism, the largest of the three trading mechanisms, involved over 7,500 in projects in more than 95 developing countries).

96. United Nations Framework Convention on Climate Change ("UNFCCC") arts. 4.3, 4.4. and 11, 31 I.L.M. 849, May 9, 1991; Kyoto Protocol to the United Nations Framework Convention on Climate Change art. 11, Conference of the Parties, 3d Sess., Dec. 10, 1997, UN Doc FCCC/CP.1997/L.7/Add.1, 37 I.L.M. 22; Paris Agreement to the United Nations Framework Convention on Climate Change art. 9, Apr. 22, 2016. 
support relating to instrument design and development of institutional capacity to other jurisdictions.

Implementation of a carbon tax or ETS usually requires specific legislation and regulations. Once implemented, changes to the tax rate or coverage often can be made as part of a budget. Changes to the rules governing an ETS tend to require changes to regulations and legislation, which usually involves a process of notice and consultation. In the case of multi-jurisdiction ETSs, such as the EU ETS and RGGI, changes can take several years to implement. No attempt has yet been made to implement a carbon tax that is harmonized across multiple jurisdictions.

We are not aware of data on the cost of implementing and administering an ETS or a carbon tax. ${ }^{97}$ The administrative costs of environmental taxes, rather than carbon taxes specifically, are reported to be low. ${ }^{98}$ Data on tax avoidance for carbon taxes and various possible forms of corruption for ETSs also are very scarce. Sweden reports a carbon tax evasion rate of $1 \%$ and the UK estimates an energy tax evasion rate of about $2 \% .{ }^{99}$

\section{REDUCTIONS IN EMISSIONS SUBJECT TO CARBON TAXES}

This section assesses the GHG emissions changes in jurisdictions that have implemented carbon taxes, reviews other assessments of the performance of the British Columbia and early European carbon taxes, compares changes in non-ETS and taxed emissions for European carbon taxes since 2008, and reviews factors that limit the performance of carbon taxes.

\section{A. Changes in emissions subject to carbon taxes}

To assess the impact of a carbon tax on the emissions by sources subject to the tax, we need data on taxed emissions. We did not find a single jurisdiction that regularly reports the emissions subject to any of its carbon taxes. ${ }^{100}$ The absence of such data probably reflects the fact

97. See Jonathan L. RAMSEur, The Regional Greenhouse Gas Initiative: LESSONS LEARNED AND ISSUES FOR CONGRESS 12 (Cong. Res. Serv. 2017) (reporting that that $5 \%$ of RGGI's auction revenue is used for administration and RGGI Inc. which manages the system).

98. See EUROPEAN ENV'T AgENCY, ENVIRONMENTAL TAXATION AND EU ENVIRONMENTAL POLICIES 16 (2016), https://www.eea.europa.eu/publications/environmentaltaxation-and-eu-environmental-policies (reporting administrative costs for German and UK environmental taxes at less than $0.5 \%$ ).

99. See id. (showing that both rates are much lower than the evasion rates for other taxes).

100. See infra Annex I (Denmark, Ireland and Slovenia have two carbon taxes while Norway 
that governments are interested primarily in collecting the taxes due and therefore do not require the taxpayers to report the associated $\mathrm{CO}_{2} \mathrm{e}$ emissions. Governments could, of course, easily calculate the $\mathrm{CO}_{2} \mathrm{e}$ emissions from the data provided.

We estimate the emissions covered by a carbon tax by dividing the carbon tax revenue collected by the tax rate per $\mathrm{tCO}_{2} \mathrm{e}$. That requires data on the carbon tax revenue collected and the tax rate which, fortunately, are available for many jurisdictions. We were not able to collect the requisite data for Estonia, Finland, Latvia, Mexico, Poland, or Portugal. We were not able to collect the required data for a few years after implementation of the carbon taxes in Denmark, Norway, Slovenia, and Sweden either. The data on tax revenue, tax rate, and estimated taxed emissions by jurisdiction and tax are presented in Annex 1.

As discussed in section III.A, this calculation estimates actual emissions subject to the carbon tax with no adjustments for leakage or emission changes due to use of the tax revenue. Ireland has different carbon taxes for two groups of fossil fuels. Denmark and Slovenia each have two carbon taxes-on specified $\mathrm{CO}_{2}$ emissions and on sales of fluorinated gases - while Norway also taxes emissions by offshore oil and gas activities for a total of three. Since some carbon taxes apply discounted tax rates to emissions by specified sources, the calculation tends to understate the emissions subject to the carbon tax somewhat. However, focusing on the annual rates of change and using the estimated emissions during the first year as the base minimizes the effect of such underestimation.

We ignore small changes in the coverage of the tax. For example, British Columbia offered a one-time exemption (worth CAD 7.6 million) from the carbon tax for greenhouse operators in 2012. ${ }^{101}$ The 2013 budget changed this to an ongoing $80 \%$ reduction of the tax for greenhouse operators. ${ }^{102}$ Gasoline and diesel used for agriculture were exempted from the carbon tax by the 2014 budget. ${ }^{103}$ For different

has three).

101. At the tax rate of $\mathrm{CAD} 30 / \mathrm{tCO} 2$, the exemption represented about $0.25 \mathrm{MtCO} 2$, about $0.67 \%$ of the emissions covered by the tax. Information on the magnitude of the agricultural fuel exemption is not available, but the changes in the annual emissions suggest that it is small as well. See Brian Murray \& Nicholas Rivers, British Columbia's Revenue-Neutral Carbon Tax: A Review of the Latest "Grand Experiment" 4-5 (Nicholas Inst., Working Paper No. 15-04, 2015), http://nicholasinstitute.duke.edu/publications (listing exemptions).

102. B.C. Ministry OF FinAnCE, BudGet AND FisCAL Plan, 2013/14-2015/16 60 (2013), https://www.bcbudget.gov.bc.ca/2013/bfp/2013_Budget_Fiscal_Plan.pdf.

103. Nicholas Rivers \& BRANDON SCHAufEle, PAC. InST. Climate Sols., THE EFFECT 
jurisdictions, the data relate to calendar or fiscal years. Comparisons of annual rates of change are valid across jurisdictions with different fiscal years.

We were able to estimate taxed emissions for 17 carbon taxes in 12 jurisdictions. Table 2 compares our estimates of the 2016 taxed emissions by all of a jurisdiction's carbon taxes as a share of its total GHG emissions, excluding land use, land use change, and forestry (LULUCF) emissions, with those from Métivier et al. reported in Table 1. Since Métivier et al. was published early in 2017, the shares it reports probably relate to 2015 or 2016, but the data and the methodology used to calculate the shares reported are not specified. Thus, it is not possible to explain the reasons for differences between our estimated shares and those reported by Métivier et al.

Table 2. Taxed Emissions as a Share of Total GHG Emissions

\begin{tabular}{|l|c|c|}
\hline Jurisdiction & $\begin{array}{c}\text { Estimates } \\
\text { from Table } \\
\mathbf{1}\end{array}$ & $\begin{array}{c}\text { Estimates from tax } \\
\text { revenue and tax rate for } \\
\mathbf{2 0 1 6}\end{array}$ \\
\hline Norway & $60 \%$ & $58 \%$ \\
\hline Sweden & $42 \%$ & $40 \%$ \\
\hline Denmark & $45 \%$ & $44 \%$ \\
\hline Slovenia & $24 \%$ & $44 \%$ \\
\hline $\begin{array}{l}\text { British } \\
\text { Columbia }\end{array}$ & $70 \%$ & $68 \%$ \\
\hline Liechtenstein & $26 \%$ & $28 \%$ \\
\hline Switzerland & $35 \%$ & $26 \%$ \\
\hline Ireland & $33 \%$ & $30 \%$ \\
\hline Iceland & $55 \%$ & $62 \%$ \\
\hline Japan & $70 \%$ & $65 \%$ \\
\hline UK & $25 \%$ & $12 \%$ \\
\hline France & $40 \%$ & $39 \%$ \\
\hline $\begin{array}{l}\text { Sources: Table 1 and estimates of taxed emissions from } \\
\text { Annex 1 divided by total GHG emissions excluding } \\
\text { LULUCF. }\end{array}$ \\
\hline
\end{tabular}

OF BRITISH COLUMBIA's CARBON TAX ON AGRICUlturAL TRADE 6 (2014) (stating that farmers were exempted from the carbon tax on the purchase of colored gasoline and colored diesel fuel for farm use effective January 1, 2014). 
The two estimates are surprisingly close except for Iceland, Slovenia, Switzerland, and the UK. In the case of the UK, the reason may be the rapid decline in emissions by coal-fired generating units subject to the carbon price floor: using our 2015 data yields a share of $23 \%$ rather than $12 \%$. Our estimates of taxed emissions also yield reasonable shares of total GHG emissions and of non-ETS emissions, where applicable, over time. In short, we feel our estimates of taxed emissions are reasonable and suitable for assessing the performance of the carbon taxes.

The annual rate of change of taxed emissions for each of the 17 carbon taxes for which we have data is shown in Table 3. Only six of the 17 taxes have reduced actual emissions-Denmark (duty on $\mathrm{CO}_{2}$ ), Japan, Slovenia (fluorinated gases), Sweden, Switzerland and the UK. The rates of change of taxed emissions vary widely, from a reduction of over $42 \%$ per year for the UK carbon price floor to an increase of more than 24\% per year for fluorinated gases in Denmark.

Table 3. Annual Rate of Change of Taxed Emissions by Carbon Tax

\begin{tabular}{|l|c|c|}
\hline \multicolumn{1}{|c|}{ Jurisdiction/tax } & $\begin{array}{c}\text { Time } \\
\text { period }\end{array}$ & $\begin{array}{c}\text { Annual rate of } \\
\text { change of taxed } \\
\text { emissions (\%) }\end{array}$ \\
\hline Norway & & \\
\hline Tax on CO2 emissions & $\begin{array}{c}1994- \\
2016\end{array}$ & 2.10 \\
\hline $\begin{array}{l}\text { Tax on offshore CO2 } \\
\text { emissions }\end{array}$ & $\begin{array}{c}1999- \\
2016\end{array}$ & 5.22 \\
\hline Tax on fluorinated gases & $\begin{array}{c}2003- \\
2016\end{array}$ & 3.46 \\
\hline Sweden & $\begin{array}{c}1993- \\
2016\end{array}$ & -1.91 \\
\hline Denmark & & \\
\hline Duty on CO2 emissions & $\begin{array}{c}1994- \\
2016\end{array}$ & -2.31 \\
\hline Tax on fluorinated gases & $\begin{array}{c}2013- \\
2016\end{array}$ & 24.08 \\
\hline Slovenia & $1999-$ & \\
\hline Tax on CO2 emissions & 2016 & 1.24 \\
\hline Tax on fluorinated gases & $\begin{array}{c}2010- \\
2016\end{array}$ & -11.23 \\
\hline
\end{tabular}




\begin{tabular}{|l|c|c|}
\hline Jurisdiction/tax & $\begin{array}{c}\text { Time } \\
\text { period }\end{array}$ & $\begin{array}{c}\text { Annual rate of } \\
\text { change of taxed } \\
\text { emissions (\%) }\end{array}$ \\
\hline British Columbia & $\begin{array}{c}2008- \\
2016\end{array}$ & 3.62 \\
\hline Switzerland & $\begin{array}{c}2008- \\
2016\end{array}$ & -4.50 \\
\hline Liechtenstein & $\begin{array}{c}2009- \\
2016\end{array}$ & 2.12 \\
\hline Ireland & $\begin{array}{c}2011- \\
2016\end{array}$ & 1.41 \\
\hline $\begin{array}{l}\text { Natural gas and liquids } \\
\text { carbon tax }\end{array}$ & $\begin{array}{c}2015- \\
2016\end{array}$ & 14.93 \\
\hline Solid fuel carbon tax & $\begin{array}{c}2011- \\
2015\end{array}$ & 2.91 \\
\hline Iceland & $\begin{array}{c}2013- \\
2016\end{array}$ & -3.29 \\
\hline Japan & $\begin{array}{c}2014- \\
2016\end{array}$ & -42.54 \\
\hline UK & $\begin{array}{c}2015- \\
2016\end{array}$ & 5.45 \\
\hline France & \multicolumn{2}{|l}{} \\
\hline Source: Calculated from emissions data in Annex 1 \\
\hline
\end{tabular}

An increase in emissions after implementation of the carbon tax does not mean the tax had no impact; only that the tax was not sufficient to reverse a trend of rising emissions. The studies reviewed in the next section assess taxes in terms of their impact on business-asusual emissions. As noted earlier, we believe our criterion of a reduction in actual emissions is more appropriate given the GHG targets of the jurisdictions that have implemented the taxes.

\section{B. Other assessments of the performance of carbon taxes}

This section summarizes other studies that have assessed the performance of carbon taxes. Those studies fall into two groups: estimates of the impact of British Columbia's carbon tax and assessments of the carbon taxes implemented by European countries prior to 2008 . 


\section{Estimates of the impact of British Columbia's carbon tax}

British Columbia's carbon tax went into effect on July 1, 2008 at $\mathrm{CAD} 10 / \mathrm{tCO}_{2}$. The tax increased at a rate of CAD $5 / \mathrm{tCO}_{2}$ per year to CAD $30 / \mathrm{tCO}_{2}$ per year on July 1, 2012. ${ }^{104}$ The tax rate remained at CAD 30/ $\mathrm{tCO}_{2}$ for the next five years. ${ }^{105}$ Six published estimates of the impact of the tax are summarized in Table 4. All are limited to the period when the tax rate was rising annually. Four of the estimates focus on per capita or per household gasoline consumption, which accounts for about a quarter of the taxed emissions. The results reported suggest that the tax reduced emissions by $5 \%$ to $15 \%$ from what they would have been. ${ }^{106}$

In Table 4 the published estimates are adjusted, where appropriate, for population growth and then expressed as an annual change in total emissions. With one exception, the estimated impacts are equivalent to an annual reduction of business-as-usual emissions of less than $2 \%$, so actual emissions could increase despite the impact of the tax.

Although it is not evident from the data in Table 4, Erutku and Hildebrand find that the impact began to diminish after the tax rate was frozen. ${ }^{107}$ Lawley and Thiverge find that the urban households reduced gasoline consumption more than rural households because they have more transportation options. ${ }^{108}$ Both results are consistent with the expected responses to a carbon tax.

In summary, all studies have found that the carbon tax reduced the emissions an analyzed relative to business-as-usual while the tax rate was rising. Our data indicate that taxed emissions increased both during the initial five years as the tax rate rose and during the subsequent five years when the tax rate remained constant. These results are not inconsistent. Rather, they indicate that our criterion, as stated earlier, is more stringent.

104. Eduardo Porter, Does a Carbon Tax Work? Ask British Columbia, N.Y. TIMES (Oct. 5, 2018), https://www.nytimes.com/2016/03/02/business/does-a-carbon-tax-work-ask-britishcolumbia.html.

105. Id.

106. See generally Murray \& Rivers, supra note 101 (drawing this conclusion based on a range of different studies).

107. See Can Erutku \& Vincent Hildebrand, Carbon Tax at the Pump in British Columbia and Quebec, 44 CAN. PUB. POL'Y 126, 131 (2018) ("[G]asoline consumption per capita in British Columbia started to increase after April 2012 (it had been on a declining trend since 2004) as the carbon tax peaked on and remained constant after July 2012[.]”).

108. Chad Lawley \& Vincent Thivierge, Refining the Evidence: British Columbia's Carbon Tax and Household Gasoline Consumption, 39 ENERGY J. 147, 168 (2018). 
Table 4. Estimates of the Impact of British Columbia's Carbon Tax on Taxed Emissions

\begin{tabular}{|c|c|c|c|c|c|}
\hline Study & Methodology & Years & $\begin{array}{l}\text { Change in } \\
\text { per capita } \\
\text { Emissions }\end{array}$ & $\begin{array}{l}\text { Change in } \\
\text { Total } \\
\text { Emissions } \\
\text { (TE) }\end{array}$ & $\begin{array}{c}\text { Change } \\
\text { in TE per } \\
\text { Year }\end{array}$ \\
\hline \multirow[t]{2}{*}{$\begin{array}{l}\text { Elgie } \\
\text { and } \\
\text { McClay } \\
109\end{array}$} & $\begin{array}{l}\text { Trend in per } \\
\text { capita } \\
\text { consumption } \\
\text { of taxed fuels } \\
\text { relative to the } \\
\text { rest of Canada } \\
\text { from } 2007- \\
2008 \text { to } 2011- \\
2012 \\
\end{array}$ & 4 & $-18.8 \%$ & $-13.65 \%$ & $-3.41 \%$ \\
\hline & $\begin{array}{l}\text { Trend in per } \\
\text { capita GHG } \\
\text { emissions } \\
\text { subject to the } \\
\text { tax relative to } \\
\text { the rest of } \\
\text { Canada from } \\
\text { 2008 to } 2011 \\
\end{array}$ & 3 & $-8.9 \%$ & $-5.28 \%$ & $-1.76 \%$ \\
\hline $\begin{array}{l}\text { Beck et } \\
\text { al. }^{110}\end{array}$ & $\begin{array}{l}\text { Simulation } \\
\text { using static } \\
\text { computable } \\
\text { general EQ } \\
\text { model of the } \\
\text { Canadian } \\
\text { economy } \\
\text { calibrated to } \\
\text { provincial } \\
\text { production and } \\
\text { consumption } \\
\text { patterns. }\end{array}$ & 5 & & $-9.14 \%$ & $-1.83 \%$ \\
\hline
\end{tabular}

109. Stewart Elgie \& Jessica McClay, BC's Carbon Tax Shift Is Working Well After Four Years (Attention Ottawa), 39 CAN. PUB. POL'Y 1, 1-6 (2013).

110. Marisa Beck et al., Carbon Tax and Revenue Recycling: Impacts on Households in British Columbia, 41 RESOURCE \& ENERGY ECON. 40, 54 (2015). 


\begin{tabular}{|c|c|c|c|c|c|}
\hline Study & Methodology & Years & $\begin{array}{l}\text { Change in } \\
\text { per capita } \\
\text { Emissions }\end{array}$ & $\begin{array}{l}\text { Change in } \\
\text { Total } \\
\text { Emissions } \\
\text { (TE) }\end{array}$ & $\begin{array}{c}\text { Change } \\
\text { in TE per } \\
\text { Year }\end{array}$ \\
\hline $\begin{array}{l}\text { Rivers } \\
\text { and } \\
\text { Schauf } \\
\text { ele }^{111}\end{array}$ & $\begin{array}{l}\text { Difference-in- } \\
\text { difference } \\
\text { estimate of per } \\
\text { capita gasoline } \\
\text { use in British } \\
\text { Columbia } \\
\text { relative to rest } \\
\text { of Canada } \\
\text { from } 1990 \\
\text { through } 2011\end{array}$ & 4 & $-8.40 \%$ & $-3.70 \%$ & $-0.93 \%$ \\
\hline $\begin{array}{l}\text { Lawley } \\
\text { and } \\
\text { Thivi- } \\
\text { erge }^{112}\end{array}$ & $\begin{array}{l}\text { Difference-in- } \\
\text { difference } \\
\text { estimate of } \\
\text { household } \\
\text { gasoline } \\
\text { spending in } \\
\text { British } \\
\text { Columbia } \\
\text { relative to rest } \\
\text { of Canada for } \\
\text { 2001-2012 }\end{array}$ & 5 & $\begin{array}{c}-6.67 \% \text { to } \\
-10.67 \%\end{array}$ & $\begin{array}{c}-1.13 \% \text { to } \\
-4.87 \%\end{array}$ & $<-0.97 \%$ \\
\hline $\begin{array}{l}\text { Erutku } \\
\text { and } \\
\text { Hilde- } \\
\text { brand } \\
113\end{array}$ & $\begin{array}{l}\text { Difference-in- } \\
\text { difference } \\
\text { estimate of per } \\
\text { capita gasoline } \\
\text { use in British } \\
\text { Columbia } \\
\text { relative to rest } \\
\text { of Canada } \\
\text { from } 1991 \\
\text { through } 2015\end{array}$ & 5 & $\begin{array}{c}-5.8 \% \text { to }- \\
16.4 \%\end{array}$ & $\begin{array}{c}-0.26 \% \text { to } \\
-10.3 \%\end{array}$ & $\leq-2.0 \%$ \\
\hline
\end{tabular}

111. Nicholas Rivers \& Brandon Schaufele, Salience of Carbon Taxes in the Gasoline Market, 74 J. EnVtL. ECON. MGMT. 23-36 (2015).

112. See Lawley \& Thivierge, supra note 108, at 168 (applying the carbon tax of 6.67 c/liter to the lower bound estimate of tax semi-elasticity of -0.010 and the baseline estimate of -0.016 yields per capita emission reduction estimates of $-6.67 \%$ and $-10.67 \%$ respectively over 5 years).

113. See generally Erutku \& Hildebrand, supra note 107, at 128. 
Note that in Table 4, impact on total emissions is calculated as the change in emissions divided by the population growth over the period. For example, the $-18.8 \%$ change in emissions is partially offset by $4.53 \%$ population growth, so the impact on total emissions is calculated as $1.188 / 1.0453=1.1365$ or a $13.65 \%$ reduction in total emissions.

2. Estimates of the impact of European carbon taxes prior to $\underline{2008}$

European countries that implemented carbon taxes prior to 2008 include Denmark; Estonia; Finland; Norway; Poland; Slovenia; Sweden and, for limited periods, Italy and the Netherlands. Some analysts treat the UK's Fossil Fuel Levy and Climate Change Levy, which were implemented during this period, as carbon taxes, though the tax rates were not related to the GHG emissions produced by the fuels. We found estimates of the emissions reductions achieved by the taxes in Denmark, Finland, Norway and Sweden as well as multicountries that also cover Austria, Germany, Italy, Netherlands and the UK. The findings of those studies are summarized in Table 5. Some of the national studies estimate reductions only for part of the emissions covered by the tax, such as transport or industrial emissions. 
Table 5. Estimates of the Impact of European Carbon Taxes on Taxed Emissions

\begin{tabular}{|l|c|l|c|}
\hline $\begin{array}{l}\text { Carbon Tax } \\
\text { Jurisdiction }\end{array}$ & $\begin{array}{c}\text { Time } \\
\text { Period }\end{array}$ & \multicolumn{1}{|c|}{ Emission Reductions } & $\begin{array}{c}\text { Reduction } \\
\text { per Year }\end{array}$ \\
\hline $\begin{array}{l}\text { Denmark } \\
\text { Bjørner and } \\
\text { Jensen, } \\
2002^{114}\end{array}$ & $1992-$ & $\begin{array}{l}\text { Energy taxes reduced 1997 BAU } \\
\text { energy use by industry by 10\% } \\
\text { based on comparison of firms } \\
\text { that paid full and reduced tax } \\
\text { rates. }\end{array}$ & $2 \%$ \\
\hline $\begin{array}{l}\text { Denmark } \\
\text { Andersen, } \\
\text { et al, 200015 }\end{array}$ & $1990-$ & $\begin{array}{l}\text { Danish } \mathrm{CO}_{2} \text { emissions adjusted } \\
\text { for weather and electricity } \\
\text { exports fell by some 4\%. }\end{array}$ & $<1 \%$ \\
\cline { 2 - 4 } & $1990-$ & $\begin{array}{l}\text { Danish } \mathrm{CO}_{2} \text { emissions adjusted } \\
\text { for weather and electricity } \\
\text { exports fell by some 8\%. }\end{array}$ & $1 \%$ \\
\hline $\begin{array}{l}\text { Finland } \\
\text { Economic } \\
\text { Council, } \\
\text { 2000 }\end{array}$ & $1990-$ & $\begin{array}{l}\text { With no change to the 1990 } \\
\text { energy taxes, Finnish CO } 2 \\
\text { emissions would have been 7\% } \\
\text { higher in 1998. }\end{array}$ & $<1 \%$ \\
\hline $\begin{array}{l}\text { Norway } \\
\text { Larsen and } \\
\text { Nesbakken } \\
1997^{117}\end{array}$ & $1991-$ & $\begin{array}{l}\text { CO }{ }_{2} \text { emissions due to oil } \\
\text { combustion for stationary use by } \\
\text { households and industry and } \\
\text { household transport declined by } \\
\text { 3-4\%. }\end{array}$ & $<2 \%$ \\
\hline
\end{tabular}

114. Thomas Bue Bjørner \& Henrik Holm Jensen, Energy Taxes, Voluntary Agreements and Investment Subsidies-A Micro-Panel Analysis of the Effect on Danish Industrial Companies' Energy Demand, 24 RESOURCE ENERGY ECON. 229, 243 (2002).

115. Mikael Skou Andersen et al., An Evaluation of the Impact of Green Taxes in the Nordic Countries, TemaNord 2000:561, 13.

116. Prime Minister's Economic Council, Environmental and Energy Taxation in FinlandPreparing for the Kyoto Challenge: Summary of the Working Group Report, Prime Minister's Office Publ'n Series 4/2000, 41-42.

117. Bodil Merethe Larsen \& Runa Nesbakken, Norwegian Emissions of CO2 1987-1994, 9 ENVTL. RESOURCE ECON. (1997) 287, § 5, 14. The emissions analyzed accounted for between $35 \%$ and $41 \%$ of taxable emissions during the period. 


\begin{tabular}{|c|c|c|c|}
\hline $\begin{array}{l}\text { Carbon Tax } \\
\text { Jurisdiction }\end{array}$ & $\begin{array}{c}\text { Time } \\
\text { Period }\end{array}$ & Emission Reductions & $\begin{array}{l}\text { Reduction } \\
\text { per Year }\end{array}$ \\
\hline $\begin{array}{l}\text { Norway } \\
\text { Bruvoll and } \\
\text { Larsen, } \\
2004^{118}\end{array}$ & $\begin{array}{c}1990- \\
1999\end{array}$ & $\begin{array}{l}\text { An applied general equilibrium } \\
\text { simulation of the effects of } \\
\text { carbon taxes finds that they } \\
\text { reduced } \mathrm{CO}_{2} \text { emissions by } \\
2.3 \% \text { over the period. }\end{array}$ & $<1 \%$ \\
\hline $\begin{array}{l}\text { Sweden } \\
\text { Andersen et } \\
\text { al., } 2000^{119}\end{array}$ & $\begin{array}{c}1991- \\
1994\end{array}$ & $\begin{array}{l}\text { Model estimate finds } 1994 \mathrm{CO}_{2} \\
\text { emissions } 3-5 \% \text { lower than } \\
\text { with continuation of } 1990 \\
\text { taxes. }\end{array}$ & About $1 \%$ \\
\hline \begin{tabular}{|l|} 
Sweden \\
Bohlin, \\
$1998^{120}$ \\
\end{tabular} & $\begin{array}{c}1991- \\
1995\end{array}$ & $\begin{array}{l}\text { Overall reduction in } \mathrm{CO}_{2} \\
\text { emissions of } 1.5 \text { to } 4.5 \% \text { per } \\
\text { year due to the tax. }\end{array}$ & $\begin{array}{l}1.5 \text { to } \\
4.5 \%\end{array}$ \\
\hline $\begin{array}{l}\text { Sweden } \\
\text { Andersson, } \\
2017^{121} \\
\end{array}$ & $\begin{array}{l}1990- \\
2005\end{array}$ & $\begin{array}{l}\text { The tax resulted a } 6.3 \% \\
\text { reduction in per capita } \mathrm{CO}_{2} \\
\text { transport emissions in an } \\
\text { average year. }\end{array}$ & $3.6 \%$ \\
\hline $\begin{array}{l}\text { Denmark, } \\
\text { Finland, } \\
\text { Netherlands, } \\
\text { Norway, } \\
\text { Sweden } \\
\text { Lin and Li, } \\
2011^{122}\end{array}$ & $\begin{array}{l}\text { Incep- } \\
\text { tion to } \\
2008\end{array}$ & $\begin{array}{l}\text { Significant negative impact on } \\
\text { the growth of per capita } \mathrm{CO}_{2} \\
\text { emissions in Finland. Negative, } \\
\text { but not significant, impact on } \\
\text { per capita } \mathrm{CO}_{2} \text { emissions in } \\
\text { Denmark, Sweden and } \\
\text { Netherlands. Insignificant } \\
\text { positive impact in Norway. }\end{array}$ & \\
\hline \begin{tabular}{|l|} 
Austria, \\
Denmark, \\
Finland, Italy, \\
Netherlands, \\
Sweden and \\
UK \\
Mideksa and \\
Kallbekken, \\
undated $^{123}$
\end{tabular} & $\begin{array}{l}\text { Incep- } \\
\text { tion to } \\
2008\end{array}$ & $\begin{array}{l}\text { Carbon taxes led to statistically } \\
\text { significant reductions in } \mathrm{CO}_{2} \\
\text { emissions only for Sweden and } \\
\text { the UK (the Climate Change } \\
\text { Levy). }\end{array}$ & \\
\hline
\end{tabular}

118. Annegrete Bruvoll \& Bodil Merethe Larsen, Greenhouse Gas Emissions in Norway Do Carbon Taxes Work, 32 ENERGY POL'Y 500, § 5, 9 (2004). 


\begin{tabular}{|l|c|l|c|}
\hline $\begin{array}{c}\text { Carbon Tax } \\
\text { Jurisdiction }\end{array}$ & $\begin{array}{c}\text { Time } \\
\text { Period }\end{array}$ & \multicolumn{1}{|c|}{ Emission Reductions } & $\begin{array}{c}\text { Reduction } \\
\text { per Year }\end{array}$ \\
\hline $\begin{array}{l}\text { Denmark, } \\
\text { Finland, } \\
\text { Germany, } \\
\text { Netherlands, } \\
\text { Slovenia, } \\
\text { Sweden and } \\
\text { UK } \\
\text { Andersen, } \\
2010^{124}\end{array}$ & $1994-$ & $\begin{array}{l}\text { Review of available studies of } \\
\text { the impacts of environmental } \\
\text { tax reforms finds no change in } \\
\text { GHG emissions in Slovenia, an } \\
\text { average reduction of 3.1\% in } \\
\text { the other six countries with the } \\
\text { largest reduction }(5.9 \%) \text { in } \\
\text { Finland }\end{array}$ & $<1 \%$ \\
\hline
\end{tabular}

The national estimates, including those summarized by Andersen, indicate that the respective carbon taxes reduced business-as-usual emissions by less than $2 \%$ per year. That likely is less than the rate of growth of business-as-usual emissions. It is not surprising, then, that taxed emissions during this period increased in Denmark and Norway although they declined in Sweden (see Annex 1). ${ }^{125}$

The two econometric studies spanning multiple countries yield inconsistent results in terms of the countries whose taxes significantly affect $\mathrm{CO}_{2}$ emissions. They specify different countries as having a carbon tax and consequently different countries as being part of the

119. Andersen et al., supra note 115, at 58.

120. Folke Bohlin, The Swedish Carbon Dioxide Tax: Effects on Biofuel Use and Carbon Dioxide Emissions, 15 BIOMASS AND BIOENERGY 283, 283 (1998). The estimated abatement of 0.5 to 1.5 million tons $\mathrm{CO} 2$ on a yearly basis is equivalent to a $1.5 \%$ to $4.5 \%$ reduction of emissions subject to the $\mathrm{CO} 2$ tax.

121. Julius J. Andersson, Cars, Carbon Taxes and CO2 Emissions 32 (Grantham Research Inst. on Climate Change \& the Env't, Working Paper No. 212, 2017). Statistics Sweden reports that the population increased from $8,590,630$ in 1990 to $9,047,752$ in 2005, an increase of $5.3 \%$ over the period. Statistics Sweden, Population and Population Changes 1749-2017, https:/www.scb.se/en/finding-statistics/statistics-by-subject-area/population/populationcomposition/population-statistics/pong/tables-and-graphs/yearly-statistics--the-whole-country/ population-and-population-changes/. For an average year, the $6.3 \%$ reduction in per capita transport emissions would be partially offset by a $2.6 \%$ increase in population, resulting in a $3.9 \%$ reduction in actual $\mathrm{CO} 2$ transport emissions.

122. Lin \& Li, supra note 13 , at 5144 .

123. MIDEKSA \& KALLBEKKEN, supra note 13, at 5 ("[A]lthough carbon taxes fail to reduce emissions in most countries, the results for Sweden and the U.K. suggest the presence of a statistically significant and negative relationship between carbon taxes and CO2 emissions.").

124. Andersen, supra note 13 , at 4 fig. 2 .

125. Estimations of taxed emissions for Finland are unavailable. 
control group. ${ }^{126}$ They also specify different control groups. ${ }^{127}$ Their dependent variables - total and per capita $\mathrm{CO}_{2}$ emissions-include many emissions sources not subject to the carbon taxes. ${ }^{128}$ Both studies find that few of the taxes led to a significant reduction in business-asusual emissions. Reductions of business-as-usual emissions are not systematically related to reductions in actual emissions. ${ }^{129}$

All of the studies conclude that the European carbon taxes reduced emissions relative to business-as-usual, but the annual reductions are relatively small. As a result, actual emissions subject to the carbon taxes continued to rise in most of these countries. Although it relates to the Norwegian carbon tax, the following statement succinctly summarizes the early European carbon tax experience: "the taxes as they are executed have limited effect, and the sectors where the tax would have been efficient, are exempted." ${ }^{130}$

\section{European carbon taxes and other policies since 2008}

Almost all of the countries with a carbon tax have been part of the EU ETS since 2008. ${ }^{131}$ With the exception of the Carbon Price Floor in the UK, the carbon taxes apply almost exclusively to non-ETS emissions. This creates a natural experiment: changes in non-ETS emissions can be compared for the group of countries with a carbon tax and the group without a tax. Carbon taxes should yield larger reductions in non-ETS emissions for the group with taxes. For individual countries where we have data, estimates of changes in taxed emissions can be compared with changes in non-ETS emissions. Carbon taxes should reduce taxed emissions more than non-ETS emissions.

126. Compare Lin \& Li, supra note 13, at 5140 (including Austria in the control group), with MIDEKSA \& KALLBEKKEN, supra note 13, at 3 (considering Austria to have a carbon tax).

127. Compare Lin \& Li, supra note 13, at 5140 (including only European OECD countries in the control group), with MIDEKSA \& KALLBEKKEN, supra note 13 at 3 (including European and non-European OECD members in the control group).

128. Compare Lin \& Li, supra note 13, at 5140 (using per capita $\mathrm{CO} 2$ emissions as their dependent variable), with MiDEKSA \& KALLBEKKEN, supra note 13, at 3 (using total CO2 emissions as their dependent variable).

129. If business-as-usual emissions are rising rapidly statistically significant reductions may not be sufficient to lower actual emissions subject to the carbon tax. If business-as-usual emissions are growing slowly (or declining), statistically insignificant reductions could lower actual emissions.

130. Bruvoll \& Larsen, supra note 118 , at 501.

131. See supra Table 1. Japan and Switzerland have a tax but are not part of the EU ETS. Croatia is not included in the non-tax group because it did not join the EU ETS until 2013. 
Excluding the UK, thirteen countries that participate in the EU ETS have a carbon tax, including countries for which we do not have data on emissions subject to the carbon tax. ${ }^{132}$ Three of those countries-Iceland, Liechtenstein, and Norway-are not part of the EU. Sixteen countries that participate in the EU ETS do not have a carbon tax. ${ }^{133}$ The countries with a carbon tax account for roughly $33 \%$ of the total GHG emissions (excluding LULUCF) and $34 \%$ of the nonETS emissions of the 29 countries. Several of the carbon taxes were introduced after 2008; when comparing rates of emission reduction since 2008 , this favors carbon taxes.

The EU effort-sharing allocations provide a rough indication of the comparability of the tax and non-tax groups in terms of their expected reductions in non-ETS emissions. The effort-sharing allocations are national targets for reduction of non-ETS emissions from 2013 through $2020 .{ }^{134}$ The allocations reflect politically negotiated judgments on equity, emission reduction potential and other considerations. Since they are not member states, the effort-sharing allocations do not apply to Iceland, Liechtenstein, and Norway, leaving 10 countries in the tax group with such allocations. In aggregate, the annual reductions in non-ETS emissions required from the 10 tax countries exceed those of the group without a tax by $-1.16 \%$ to $0.98 \% .{ }^{135}$ In short, the two groups are reasonably comparable although the tax countries are expected to achieve slightly larger annual reductions in their non-ETS emissions.

The EU member states are expected to meet their effort-sharing allocations with EU-wide, national and sub-national policies. EU-wide policies that help reduce non-ETS emissions include $\mathrm{CO}_{2}$ standards for

132. See MÉtIVIER ET AL., supra note 27, at 3 (listing jurisdictions with carbon taxes, including thirteen which participate in the EU ETS: Denmark, Estonia, Finland, France, Iceland, Ireland, Latvia, Liechtenstein, Poland, Portugal, Norway, Slovenia, and Sweden). The UK is excluded because its Carbon Price Floor applies to emissions covered by the EU ETS. David Hirst, Carbon Price Floor (CPF) and the Price Support Mechanism 7 (House of Commons Library, Briefing Paper No. 05927, 2018).

133. Austria, Belguim, Bulgaria, Cyprus, Czech Republic, Germany, Greece, Hungary, Italy, Lithuania, Luxembourg, Malta, Netherlands, Romania, Slovakia, and Spain.

134. Decision 406/2009 of the European Parliament and of the Council of 23 April 2009, 2009 O.J. (L 140) 137; Commission Decision 2013/634, annex I, 2013 O.J. (L 292) 21 (EC). The policy came into effect in 2013, so earlier data are not available. The 2013 to 2020 period is assumed to provide a better comparison of the comparability of the tax and non-tax groups.

135. See Commission Decision 2013/634, annex I, 2013 O.J. (L 292) 21 (EU) (providing the adjustments to Member States' annual emission allocations for the period from 2013 to 2020). Among the countries with a carbon tax, the national allocations range from $-3.08 \%$ per year for Ireland to $+1.09 \%$ per year for Latvia. For non-tax countries, the national allocations range from $-5.53 \%$ per year for Cyprus to $+2.13 \%$ per year for Romania. 
road vehicles and standards for buildings and energy-related products. Member states, their sub-national jurisdictions, public entities, and private entities are expected to implement additional measures, which may include a carbon tax, to meet their allocation. The rates of change of non-ETS emissions for $2008-16$ were $-1.10 \%$ per year for the 13 countries with a carbon tax and $-1.28 \%$ per year for the 16 countries without a tax. ${ }^{136}$ Thus, despite having implemented carbon taxes, nonETS emissions declined less in the countries with a tax suggesting that other policies and developments contributed to the emission reductions in all of the countries.

A recent evaluation of the Swiss carbon tax used two different models and a large survey of taxed and tax-exempt businesses to estimate its impact on emissions. ${ }^{137}$ All three approaches estimated that the tax reduced emissions. Cumulative reductions to 2015 are estimated at 4.1 to $8.6 \mathrm{MtCO}_{2}(3.5 \%$ to $7.0 \%)$ with relatively larger reductions in 2015 ( 0.8 to $1.8 \mathrm{MtCO}_{2}, 4.3 \%$ to $9.6 \%$ ) due to increases in the tax rate. The residential sector accounts for about $75 \%$ of the reductions. One of the models was used to analyze the impact of other measures and concluded that they accounted for about $25 \%$ of the emission reductions in 2015.

The rates of change in non-ETS emissions and taxed emissions for specific countries are compared in Table 6. In most of the countries, taxed emissions represent a large share of the non-ETS emissions. If the decline in taxed emissions exceeds the decline in non-ETS emissions, the tax is likely helping to reduce the non-ETS emissions. If non-ETS emissions decline faster than the taxed emissions, the policies and other factors responsible for the decline in the non-ETS emissions likely helped to reduce the taxed emissions as well. In only one of the seven countries-Denmark-did the taxed emissions decline more than the non-ETS emissions, again suggesting that other policies and developments contributed to the reduction of taxed emissions.

136. The recession of 2009 led to a substantial decline in emissions for 2009 with a partial recovery in 2010. Rates of change calculated from 2008 are not impacted by the effects of the recession.

137. See generally Bundesamt für Umwelt BAFU, Faktenblatt Wirkungsabschätzung und Evaluation der CO2-Abgabe auf Brennstoffe (Feb. 19, 2018) (Switz.), https:/www.bafu.admin.ch/dam/bafu/de/dokumente/klima/fachinfo-daten/ wirkungsabschaetzungco2-abgabefaktenblatt.pdf. 
Table 6. Annual Rates of Change in non-ETS Emissions and Taxed Emissions Selected Countries and Periods

\begin{tabular}{|c|c|c|c|c|}
\hline Country & Period & $\begin{array}{c}\text { Change } \\
\text { in non- } \\
\text { ETS } \\
\text { emissions }\end{array}$ & $\begin{array}{c}\text { Change } \\
\text { in taxed } \\
\text { emissions }\end{array}$ & $\begin{array}{c}\text { Taxed as \% of } \\
\text { non-ETS } \\
\text { emissions } 2016\end{array}$ \\
\hline Denmark & $\begin{array}{c}2008- \\
2016\end{array}$ & -1.96 & -10.61 & $67 \%$ \\
\hline Iceland & $\begin{array}{c}2010- \\
2016\end{array}$ & -8.37 & -3.08 & $101 \%$ \\
\hline Ireland & $\begin{array}{c}2010- \\
2016\end{array}$ & -0.05 & 2.76 & $42 \%$ \\
\hline Norway & $\begin{array}{c}2008- \\
2016\end{array}$ & -3.03 & -2.49 & $57 \%$ \\
\hline Slovenia & $\begin{array}{c}2008- \\
2016\end{array}$ & -1.68 & 15.93 & $70 \%$ \\
\hline Sweden & $\begin{array}{c}2008- \\
2016\end{array}$ & -3.18 & -2.13 & $64 \%$ \\
\hline Switzerland & $\begin{array}{c}2013- \\
2016\end{array}$ & -2.46 & -2.13 & $29 \%$ \\
\hline
\end{tabular}

The EU climate and energy package that became law early in 2009 comprised of legislation to reduce EU GHG emissions by at least $20 \%$ below 1990 levels by 2020, supply at least $20 \%$ of EU energy consumption from renewable resources by 2020 , and improve energy efficiency by at least $20 \%$ relative to projected levels by 2020 . Energy efficiency and renewable energy measures implemented by residential, commercial, and small industrial facilities would contribute to lower taxed emissions.

In summary, while taxed emissions have declined since 2008 in several European countries, non-ETS emissions, with the exception of those of Denmark, have experienced larger reductions. This suggests that other policies and developments probably have contributed substantially to the observed reductions in taxed emissions in countries that have implemented carbon taxes.

C. Why have carbon taxes had such limited impact on emissions?

A carbon tax should increase the prices of emitting activities, providing an incentive to consumers to shift to less polluting activities. If the tax is to be effective, the tax rate must be sufficiently high to 
motivate consumers to change their consumption patterns. If the emission reductions are to be sustained, or increased, the tax rate must be adjusted for inflation, increases in income, and the effects of technological change. This section argues that, with few exceptions, tax rates have been too low to have a significant impact on consumption patterns, tax rates often are not adjusted with the frequency and scale needed to sustain or increase the emission reductions, and the empirical relationship between tax rate increases and emission reductions is not well understood.

\section{Tax rates}

Carbon taxes are applied mainly to transportation fuels and fossil fuels used for residential, commercial, and institutional heating. ${ }^{138} \mathrm{In}$ most jurisdictions, these fuels are subject to excise and other taxes regardless of whether they are also subject to a carbon tax. The price signal to the consumer is the effect of the carbon tax on the retail price, including all other taxes. In a few jurisdictions, Finland and Sweden for example, the introduction of the carbon tax was accompanied by a corresponding reduction in the amount of excise tax. In those cases, the carbon tax has no impact on the retail price until the carbon tax exceeds the excise tax reduction.

The price elasticity of demand measures the consumer response to a change in the price of a product. For transportation fuels the price elasticity is low (highly inelastic) in the short run and more elastic in the long run. ${ }^{139}$ This means that the initial response to a price increase is small, but a larger adjustment will occur over time if the price increase is sustained. In other words, to produce a noticeable reduction in emissions from the consumption of gasoline and diesel fuel, a carbon tax must have a substantial impact on the retail prices of these fuels. Table 7 shows carbon taxes as a share of diesel fuel prices in various European countries for 2005-14. ${ }^{140}$

138. See WORLD BANK P'SHIP FOR MARKET READINESS, supra note 1, at 76-77 tbl.16 (detailing the scope of various planned carbon taxes).

139. See Xavier Labandeira et al., A Meta-Analysis on the Price Elasticity of Energy Demand, 102 ENERGY POL'Y 549, 553 tbl.4 (2017) (finding the average short- and long-term price elasticities of car fuels to be 0.180 and 0.372 , respectively).

140. The diesel fuel price data are not available after 2014. 
Table 7. Carbon Tax as a Share of Diesel Fuel Price 2005-14 for Selected Countries

\begin{tabular}{|c|c|c|c|}
\hline Country & $\begin{array}{c}\text { Carbon tax } \\
\text { (USD/liter) }\end{array}$ & $\begin{array}{c}\text { Diesel price } \\
\text { (USD/liter) }\end{array}$ & $\begin{array}{c}\text { Tax as \% of } \\
\text { price }\end{array}$ \\
\hline Denmark & 0.04 to 0.08 & 1.45 to 1.89 & $\begin{array}{c}2.80 \% \text { to } \\
4.42 \%\end{array}$ \\
\hline Iceland & 0.02 to 0.03 & 1.45 to 1.89 & $\begin{array}{c}0.70 \% \text { to } \\
1.38 \%\end{array}$ \\
\hline Ireland & 0.05 to 0.07 & 1.31 to 2.06 & $\begin{array}{c}3.15 \% \text { to } \\
3.86 \%\end{array}$ \\
\hline Norway & 0.08 to 0.14 & 1.69 to 2.35 & $\begin{array}{c}4.41 \% \text { to } \\
6.65 \%\end{array}$ \\
\hline Slovenia & 0.04 to 0.05 & 1.21 to 1.77 & $\begin{array}{c}2.43 \% \text { to } \\
3.83 \%\end{array}$ \\
\hline Sweden & 0.33 to 0.43 & 1.44 to 2.16 & $\begin{array}{c}19.22 \% \\
26.62 \%\end{array}$ \\
\hline
\end{tabular}

With the exception of Sweden, the carbon tax is less than $5 \%$ of the retail price and is relatively constant over time. Sweden has the highest carbon tax rates (see Table 1), so those results are not surprising. Comparison of the carbon tax (second column) with the range of diesel prices (third column) indicates that the tax is substantially smaller than fluctuations in the retail price even in Sweden. In short, the European carbon taxes, with the exception of Sweden, constitute a small, relatively fixed share of the diesel fuel price that is lost in the "noise" of price changes. Therefore, they are unlikely to have stimulated an appreciable reduction in related emissions.

Fossil fuels used for residential, commercial, and institutional heating typically are not as heavily taxed as transportation fuels, so a given tax rate would generate a larger price signal for consumers. However, research into the adoption of energy efficiency measures indicates that many market barriers inhibit adjustments to energy price increases, so the emissions reductions due to a carbon tax may be smaller and slower to materialize than projected. ${ }^{141}$

141. See Nadia Ameli \& Nicola Brandt, What Impedes Household Investment in Energy Efficiency and Renewable Energy, 8 INT'L REV. ENVTL. \& RESOURCE ECON. 101, 129 tbl.1 (2014) (citing energy prices as a barrier to energy investment and policy solutions); Todd D. Gerarden et al., Assessing the Energy-Efficiency Gap, 55 J. ECON. LiTERATURE 1486, 1486-87 (2017) ("[T]here is a broadly held view that various barriers to the adoption of energy-efficient technologies have prevented the realization of a substantial portion of these benefits."); Kenneth Gillingham \& Karen Palmer, Bridging the Energy Efficiency Gap: Policy Insights from Economic 
Other emitting activities subject to carbon taxes are more sensitive to price changes (more price elastic), but only limited information is available. The UK carbon price floor applies to fossil fuels used to generate electricity and changes the "merit order," the sequence in which generating units that use different fossil fuels are used. It was the key driver behind the rapid decline of coal-fired generation since 2013 because the tax makes many coal-fired units more costly to operate than gas-fired units. ${ }^{142}$ Australia's carbon pricing mechanism led to similar changes in the mix of generating units used there. ${ }^{143}$ In a similar vein, replacement of coal by biofuel in the district heating sector was the largest source of emission reductions attributed to the Swedish carbon tax during its early years. ${ }^{144}$

\section{Scale and frequency of tax rate changes}

Jurisdictions that implement a carbon tax must adjust the tax rate over time to achieve their emission reduction objectives. Inflation and increases in income reduce the effectiveness of a given tax rate over time. Technological change, fossil fuel price changes, and other developments can also reduce the effectiveness of a give tax rate over time. Thus, to sustain or increase the emission reductions due to a carbon tax, the tax rate must rise over time. Data on the scale and frequency of tax rate changes are presented in Table 8. For most of the taxes, the increases in the tax rate have exceeded the rate of inflation.

Theory and Empirical Evidence, 8 REV. ENVTL. ECON. \& POL'Y 18, 19 (2014) ("[M]arket failures . . . can lead to inefficiently low levels of investment in energy efficiency.").

142. See Aurora Energy Research, The Carbon Price Thaw: Post-Freeze Future OF THE GB CARBON PRICE 4 (2017) (stating that Great Britain's Carbon Price Support ("CPS"), a component of its Carbon Price Floor ("CPF"), "was the key driver behind the rapid decline of coal generation since 2013").

143. See Marianna O'Gorman \& Frank Jotzo, Impact of the Carbon Price on Australia's Electricity Demand, Supply and Emissions 26-28 (Ctr. for Climate Econ. \& Pol'y, Working Paper No. 1411, 2014) (discussing the significant impact that Australia's carbon price has had on the brown and black coal markets).

144. Bohlin, supra note 120 , at 289. 
Table 8. Scale and Frequency of Tax Rate Changes

\begin{tabular}{|c|c|c|c|c|c|}
\hline Jurisdiction/tax & $\begin{array}{l}\text { Years } \\
\text { of data }\end{array}$ & $\begin{array}{l}\text { Average } \\
\text { annual } \\
\text { change to } \\
\text { the tax } \\
\text { rate }(\%)\end{array}$ & $\begin{array}{l}\text { Average } \\
\text { annual } \\
\text { rate of } \\
\text { inflation } \\
\text { over the } \\
\text { same } \\
\text { period }\end{array}$ & $\begin{array}{l}\text { Percent of } \\
\text { years with } \\
\text { no rate } \\
\text { increase } \\
\text { after the } \\
\text { first } 5 \\
\text { years }\end{array}$ & $\begin{array}{l}\text { Longest } \\
\text { period } \\
\text { with no } \\
\text { increase } \\
\text { (years) }\end{array}$ \\
\hline \multicolumn{6}{|l|}{ Norway } \\
\hline $\begin{array}{l}\mathrm{CO} 2 \text {-tax on } \\
\text { mineral oil }\end{array}$ & 22 & 3.74 & $3.45 \%$ & $0 \%$ & 0 \\
\hline $\begin{array}{l}\text { Tax on offshore } \\
\mathrm{CO} 2 \text { emissions }\end{array}$ & 17 & -2.41 & $3.56 \%$ & $44 \%$ & 3 \\
\hline $\begin{array}{l}\text { Tax on } \\
\text { fluorinated gases }\end{array}$ & 13 & 5.98 & $3.37 \%$ & $0 \%$ & 0 \\
\hline Sweden & 23 & 5.64 & $1.68 \%$ & $52 \%$ & 5 \\
\hline \multicolumn{6}{|l|}{ Denmark } \\
\hline Duty on $\mathrm{CO} 2$ & 23 & 2.96 & $1.38 \%$ & $56 \%$ & 11 \\
\hline $\begin{array}{l}\text { Fluorinated gases } \\
\text { tax }\end{array}$ & 3 & 0.00 & $0.56 \%$ & & 4 \\
\hline \multicolumn{6}{|l|}{ Slovenia } \\
\hline Tax on $\mathrm{CO} 2$ & 17 & 1.92 & $4.73 \%$ & $79 \%$ & 14 \\
\hline $\begin{array}{l}\text { Fluorinated gases } \\
\text { tax }\end{array}$ & 6 & 18.47 & $0.96 \%$ & & 1 \\
\hline British Columbia & 8 & 14.72 & $1.03 \%$ & $100 \%$ & 4 \\
\hline Switzerland & 8 & 27.54 & $-0.12 \%$ & $25 \%$ & 2 \\
\hline Liechtenstein & 8 & 27.54 & $-0.12 \%$ & $25 \%$ & 2 \\
\hline \multicolumn{6}{|l|}{ Ireland } \\
\hline $\begin{array}{l}\text { Natural gas and } \\
\text { liquids carbon tax }\end{array}$ & 6 & 4.68 & $1.55 \%$ & & 2 \\
\hline $\begin{array}{l}\text { Solid fuel carbon } \\
\text { tax }\end{array}$ & 3 & 4.88 & $2.19 \%$ & & 1 \\
\hline Iceland & 6 & 7.80 & $3.27 \%$ & & 1 \\
\hline Japan & 4 & 44.90 & $0.94 \%$ & & 1 \\
\hline United Kingdom & 2 & 91.31 & $1.20 \%$ & & 0 \\
\hline France & 2 & 51.72 & $0.68 \%$ & & 0 \\
\hline
\end{tabular}


Over the past decade, several jurisdictions, including British Columbia, France, Japan, and the UK have phased in a carbon tax over a period of three to five years with large percentage increases every year or two over that period. Carbon taxes that have been in effect longer have much smaller average annual increases. Norway adjusts its tax rates, including its carbon tax rates, for the effect of inflation each year. These increases have not been sufficient to reduce taxed emissions. Iceland and Ireland have raised their tax rates at one- or two-year intervals, as has Slovenia for its fluorinated gases tax. Switzerland has adjusted its tax rate, which also applies in Liechtenstein, at two- or three-year intervals in an effort to achieve its emission reduction target with a substantial rate increase on each occasion. Tax rate changes in other jurisdictions appear to be more ad hoc.

Despite the annual increases to the Norwegian tax rates, the frequent increases in Switzerland, and the increases during the phasein periods in other jurisdictions, tax rates rise only about $60 \%$ of the time on a year-over-year basis. This reflects the fact that governments change and that a given government faces environmental, economic and political pressures as it considers a tax rate increase. Even announced schedules of tax rate increase are subject to change. When the UK carbon price floor was introduced in April 2013, it was scheduled to rise yearly to $£ 30 / \mathrm{tCO}_{2}$ in 2020 but was capped at $£ 18 / \mathrm{tCO}_{2}$ from 2016 in the 2014 budget. ${ }^{145}$

3. Changes to carbon tax rates and associated changes in emissions

To examine the relationship between changes in tax rates and changes in emissions, we identify periods with rising tax rates - at least four years with no more than one year without an increase. The annual rates of change for the tax rate and emissions are calculated for each of the eleven periods. The periods range in length from four to 22 years. The emissions changes are calculated for the same periods as the tax rate changes. The time period for which emission reductions are calculated should lag the time period during which rates rise, but we do not know the appropriate lag. In theory, the longer the time period, the

145. See Hirst, supra note 132, at 3 ("At Budget 2014 the Government announced that the CPS component of the floor price would be capped at a maximum of $£ 18 / \mathrm{tCO} 2$ from 2016 to 2020 to limit the competitive disadvantage faced by business and reduce energy bills for consumers. This price freeze was extended to 2021 in Budget 2016."). 
larger the share of emissions reductions should occur during the same period. ${ }^{146}$

Higher rates of tax rate increases would be expected to lead to greater emission reductions. The annual rates of changes to tax rates and emissions are shown in Figure 1. The expected relationship would be a curve sloping downward to the right. Low rates of tax rate increase might not be sufficient to reduce actual emissions, so for tax rate increases near the origin emissions might not decline (be above the horizontal axis). For high rates of tax rate increase, annual emissions would be expected to decline (be below the horizontal axis).

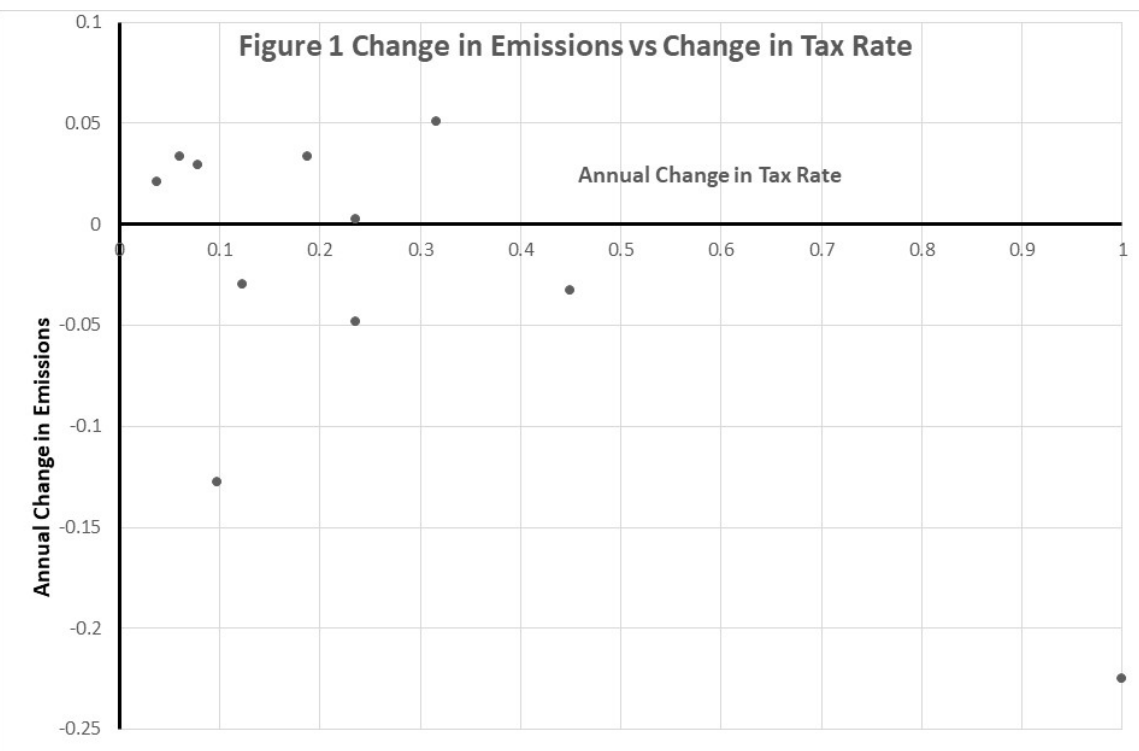

Clearly, the data relating to the existing carbon taxes do not fall neatly into the expected pattern. For tax rate changes of up to $30 \%$ per year, emissions increases ( 5 cases) are almost twice as common as emissions reductions (3 cases). The effects of other policies on emissions subject to carbon taxes may be part of the explanation, but more research into the relationship between tax rate changes and emissions reductions is needed.

146. If the lag is two years, a four-year period only captures the full effect of the tax rate change during the first two years, but a 22-year period captures the full impact for the tax rate changes during the first 20 years. 


\section{Summary}

We were able to compile emissions data for 17 carbon taxes in 12 jurisdictions. Only six of the 17 taxes have reduced actual emissions subject to the tax-Denmark (duty on $\mathrm{CO}_{2}$ ), Japan, Slovenia (fluorinated gases), Sweden, Switzerland and the UK. The rates of change of taxed emissions vary widely, from a reduction of over $42 \%$ per year for the UK carbon price floor to an increase of more than $24 \%$ per year for fluorinated gases in Denmark.

Multiple assessments of European carbon taxes implemented prior to 2008 and of the British Columbia carbon tax consistently find that carbon taxes have reduced emissions relative to business-as-usual. These assessments cover fewer taxes for shorter periods than our estimates of changes in taxed emissions. Our estimates of taxed emissions indicate that the reductions from business-as-usual were not large enough to reduce actual emissions except in the case of Sweden.

We found only one post-2008 evaluation of a European carbon tax: the Swiss tax. Comparison of post-2008 data on non-ETS emissions and taxed emissions in European countries that participate in the EU ETS suggests that other policies and developments contributed to the reduction of taxed emissions in most of those countries. The evaluation of the Swiss carbon tax estimates the contribution of other policies at about $25 \%$.

Tax rates, with the exception of Sweden and Switzerland, are probably too low to materially affect emissions by most taxed sources. Only the tax rates in Sweden, Switzerland, Liechtenstein, and Finland exceed the carbon price thought to be needed in 2020 to hold the global average temperature increase to well below $2^{\circ} \mathrm{C}$ above pre-industrial levels, in line with the Paris Agreement. ${ }^{147}$ To sustain or increase emission reductions, tax rates need to be adjusted regularly to compensate for inflation, income increases and other factors. In most jurisdictions, the scale and frequency of the rate changes has not been sufficient to stimulate further emissions reductions.

\section{REDUCTION IN EMISSIONS SUBJECT TO GHG ETSS}

This section calculates changes in emissions covered by various GHG ETSs, considers the relationship between changes in emissions

147. See WORLD BANK, supra note 25, at 34 ("Currently, only the carbon taxes in Finland, Lichtenstein, Sweden and Switzerland have carbon price rates that are consistent with the 2020 price range recommended by the High-Level Commission on Carbon Prices."); WORLD BANK CARBON PRICING LEADERSHIP COAL., supra note 77, at 51 (referring to the Paris Agreement 2030 temperature increase target of "well below $2^{\circ} \mathrm{C}$ ”). 
caps and changes in emissions, and reviews other assessments of the performance of GHG trading systems.

\section{A. Changes in emissions covered by GHG ETSS}

Most ETSs report aggregate data on the allowances and offsets surrendered and financial payments made for compliance. We used that information to calculate the verified emissions covered by the ETSs. ${ }^{148}$ As discussed in section III.A, the amounts are actual emissions with no adjustments for leakage or emission changes due to use of the ETS revenue. In a few jurisdictions-California, European Union, Quebec and Switzerland - there have been significant changes in the scope of the ETS. These are treated as separate ETSs for purposes of the analysis. The aviation component of the EU ETS likewise is treated as a separate ETS because it has its own allowances.

The annual rates of reduction are calculated using the actual emissions for the first year as the base because pre-ETS emissions data are not always available, and where available, are sometimes considered to be inflated. This approach excludes reductions during the first year of the ETS. Annual emissions data sometimes are not available for ETSs with multi-year compliance periods such as RGGI; then we use the data for the first period as the basis for calculating the second period reductions.

148. The verified emissions, in tCO2e, are equal to the sum of the allowances and other units surrendered to achieve compliance plus the emissions covered by fixed price compliance payments in Alberta and New Zealand. For the New Zealand ETS, the figure was doubled to get the verified emissions because compliance required submission of one allowance for emissions of two tCO2e. 
Table 9. Annual Rates of Change in Emissions Caps and Emissions Covered by GHG ETSs for Selected Periods ${ }^{149}$

\begin{tabular}{|c|c|c|c|c|c|c|}
\hline Jurisdiction & Period & $\begin{array}{c}\text { Average } \\
\text { Annual } \\
\text { Change in } \\
\text { Emissions } \\
\text { Cap } \\
\% / y e a r\end{array}$ & $\begin{array}{c}\text { Average } \\
\text { Annual } \\
\text { Emission } \\
\text { Change } \\
\text { \%/year }\end{array}$ & Period & $\begin{array}{c}\text { Average } \\
\text { Annual } \\
\text { Change in } \\
\text { Emissions } \\
\text { Cap } \\
\% / y e a r\end{array}$ & $\begin{array}{c}\text { Average } \\
\text { Annual } \\
\text { Emission } \\
\text { Change } \\
\% / \text { year }\end{array}$ \\
\hline $\begin{array}{l}\text { European } \\
\text { Union }\end{array}$ & $\begin{array}{c}2008- \\
2012\end{array}$ & 0 & -1.61 & $\begin{array}{c}2013- \\
2016\end{array}$ & -1.87 & -4.14 \\
\hline $\begin{array}{l}\text { EU ETS } \\
\text { Aviation }\end{array}$ & $\begin{array}{l}2012- \\
2016\end{array}$ & 0 & -7.58 & & & \\
\hline Alberta & $\begin{array}{c}2007- \\
2013\end{array}$ & NA & 2.51 & & & \\
\hline $\begin{array}{l}\text { New } \\
\text { Zealand }\end{array}$ & $\begin{array}{c}2011- \\
2016\end{array}$ & NA & 6.50 & & & \\
\hline Switzerland & $\begin{array}{c}2008- \\
2012\end{array}$ & 1.48 & -1.98 & $\begin{array}{c}2013- \\
2016\end{array}$ & -0.72 & -4.52 \\
\hline RGGI & $\begin{array}{c}2012- \\
2014\end{array}$ & -9.27 & -6.40 & & & \\
\hline Tokyo* & $\begin{array}{l}2010- \\
2015 \\
\end{array}$ & NA & -3.03 & & & \\
\hline Saitama* & $\begin{array}{l}2011- \\
2014\end{array}$ & NA & -1.36 & & & \\
\hline \multicolumn{7}{|c|}{$\begin{array}{l}\text { * These are rates of change for energy use because the carbon content of } \\
\text { electricity is assumed to be constant. The carbon content of electricity rose as a } \\
\text { result of greater reliance on fossil-fired generation due to the shutdown of most } \\
\text { nuclear generators after the } 2011 \text { great east Japan earthquake and tsunami. }\end{array}$} \\
\hline
\end{tabular}

The annual rates of change in emissions covered by the ETSs are summarized in Table 9. The data cover forty-five jurisdictions; the seven Chinese pilots are not included because they treat emissions data

149. Calculated from individual ETSs data for allowances/offsets surrendered, emissions caps, and banked allowances. Data are reported by the individual ETSs. See Alberta (http://aep.alberta.ca/climate-change/reports-and-data/default.aspx); California (https://arb.ca. gov/cc/inventory/data/data.htm); EU ETS (https:/ec.europa.eu/clima/policies/ets/ registry_en\#tab-0-1); New Zealand ETS Annual Reports and Facts and Figures (https://www.epa.govt.nz/resources-and-publications/monitoring-and-reporting/?tag=73);

Quebec (http://www.mddelcc.gouv.qc.ca/changements/carbone/Couverture-en.htm); RGGI (https://www.rggi.org/allowance-tracking/emissions); Switzerland (https://www.emissionsregistry. admin.ch/crweb/public/reporting/surrendering/list.do?org.apache.struts.taglib.html.TOKEN=5a bfbed80e6880a2d258fc5d448a684a); Tokyo (http://www.metro.tokyo.jp/ENGLISH/TOPICS/ 2016/161116.htm). For more detailed data see Masayo Wakabayashi \& Osamu Kimura, The Impact of the Tokyo Metropolitan Emissions Trading Scheme on Reducing Greenhouse Gas Emissions: Findings From A Facility-Based Study, 18 Climate Pol'y 1028, 1034 fig.2 (2018). 
as confidential. Quebec, which only reports data by compliance period, and South Korea, where the results of the first compliance period have not yet been reported, also are excluded. We exclude California from the table because the rates of change are calculated over one or two years and hence may not be indicative. The data for the two regional ETSs-EU ETS and RGGI-are aggregate, rather than jurisdictionspecific, emissions. Thus, we have data for eight ETSs, but for two of them there are two periods with different coverage yielding a total of ten jurisdictions/ETS combinations.

Actual emissions have fallen in at least six of the ETSs covering 41 jurisdictions, with annual rates of emission reductions up to $6.4 \%$. Emissions increased in Alberta, New Zealand, and possibly in Tokyo and Saitama - notably the four ETSs that do not have an emissions cap. The fact that actual emissions increased does not mean the ETS had no impact on emissions, just that the impact was not sufficient to reduce actual emissions given other developments.

The Alberta Specified Gas Emitters Regulation (SGER) applied to installations with emissions in excess of $100 \mathrm{ktCO}_{2} \mathrm{e} .{ }^{150} \mathrm{An}$ installation subject to the SGER was required to reduce emissionsintensity per unit of production by a specified percentage relative to its historic baseline. ${ }^{151}$ Aggregate emissions were not capped. The growth in actual emissions was due, in part, to an increase in the number of installations subject to the regulation and increased output by participants.

The New Zealand ETS does not have an emissions cap. ${ }^{152}$ Participants are required to submit eligible domestic and international allowances and offsets equal to half of their actual emissions. ${ }^{153}$ Until 2015 there was no limit on the use of international allowances and offsets. Beginning in 2010, the prices of those units fell significantly with the result that they accounted for over $95 \%$ of the units

150. In 2018 the Alberta SGER was replaced by the Carbon Competitiveness Incentive Regulation (CCIR). Alta. Reg. 255/2017 (Can.). For a discussion of the CCIR, see generally Mascher, supra note 15.

151. See id. at 1015 ("The SGER required covered facilities to reduce emissions-intensity (emissions per unit of production) by a specified percentage (12\% in 2007-14; $15 \%$ in 2016 ; $20 \%$ in 2017) relative to their historic performance.").

152. See Catherine Leining et al., Evolution of New Zealand Emissions Trading Scheme: Linking Lessons Learned from the New Zealand Emissions Trading Scheme 1 (Motu Econ. \& Pub. Pol'y Res., Working Paper No. 17-06, 2017) (explaining that, as of 2017, "no cap has applied to the issuance of domestic units" under the New Zealand ETS).

153. See id. at 17 (discussing the 2009 New Zealand ETS amendments that "introduce[d] a 'one-for-two' unit obligation to limit exposure of non-forestry sectors to half of the international emissions price through 2012"). 
surrendered for compliance from 2012 through 2014. ${ }^{154}$ Use of international allowances and offsets was banned after 2014. ${ }^{155}$

The Tokyo and Saitama ETSs claim emission reductions, but actual emissions may have increased. Electricity accounts for a large share of the emissions covered by these ETSs for which a constant carbon intensity is assumed. ${ }^{156}$ The great east Japan earthquake and tsunami of 2011 led to the gradual shutdown of all nuclear generating stations and greater reliance on fossil-fired generation which increased the carbon intensity of electricity supplied to Tokyo and Saitama. ${ }^{157}$

Unfortunately, the share of total emissions due to electricity use is not available for either ETS, so the impact on actual emissions cannot be calculated. Entity-specific emissions data for 985 facilities covered by the Tokyo ETS from 2010 through 2015 suggest a small increase in actual emissions due to the change in the generation mix. ${ }^{158}$

California is excluded from Table 9 because the time periods over which emission changes can be calculated are very short, so the trends may not be meaningful. Although it has multi-year compliance periods, California publishes annual emissions of entities subject to its ETS.

Our standard approach of using the first year as the base for calculating emission changes yields only a one-year change (a $0.40 \%$ increase) for the first compliance period and (a 1.68\% decline) for the second period. Using data for the year prior to the start of each phase yields two-year annual reductions of $-4.81 \%$ and $-2.79 \%$ respectively

154. Haites, supra note 37 , at 253 tbl.2.

155. See N.Z. MINISTRY FOR THE ENV'T, supra note 41, at 26 ("The New Zealand carbon market had full exposure to international markets up to the end of 2014."). Proposed changes to the New Zealand ETS set the supply of allowances on a rolling, five-year basis consistent with New Zealand's emissions target, introduce auctioning, and phase-in a one unit per tCO2 compliance obligation between 2017 and 2019. See N.Z. MINISTRY FOR THE ENV'T, IMPROVEMENTS TO THE NEW ZEALAND EMISSIONS TRADING SCHEME: CONSULTATION DOCUMENT 9-13 (Aug. 2018) (discussing proposed changes to the New Zealand ETS that the government currently seeks to introduce through legislative amendments by the end of 2019).

156. That assumption means the reported reductions are changes in energy use, rather than changes in emissions.

157. See Wakabayashi \& Kimura, supra note 149, at 1030 ("The carbon intensity of electricity increased after the earthquake in 2011 due to the shutdown of nuclear of nuclear plants, which led to a greater use of fossil-fuel generation.").

158. An analysis of compliance reports submitted by 985 facilities subject to the Tokyo ETS for the 2010-15 period indicates that the emissions intensity of electricity supplied to the Tokyo region increased as a result of greater reliance on fossil-fired generation leading to an estimated increase in emissions by those facilities of $0.35 \%$ per year. The impact on total emissions covered by the ETS is not known due to changes in the number of participating facilities. For more on the impact of the great east Japan earthquake and tsunami on emissions subject to the Tokyo ETS, see $i d$. at $1038-39$. 
for the two compliance periods. The ETS designs vary widely in terms of compliance period, price stability mechanisms, use of offsets, and other features. Yet when ETSs without an emissions cap are excluded, actual emissions have fallen.

Other policies, including vehicle fuel taxes, energy efficiency standards, and renewable energy incentives, contributed to the emission reductions. ${ }^{159}$ External factors, including changes in fuel prices and economic conditions, also had an impact. The recession and financial crisis led to a drop in emissions during 2009 in several ETSs. Additionally, a decline in natural gas prices in the US due to shale gas production led to fuel switching and lower emissions by RGGI participants.

\section{B. Changes in emissions and emissions caps}

Most jurisdictions that implement a GHG ETS limit the aggregate emissions by participants. When such an ETS is first implemented, the emissions cap tends to be generous for several reasons:

- Participants lobby for a limit that requires minimal reductions to keep compliance costs low;

- Equitable treatment of participants that implemented emission reductions prior to the start of the ETS often takes the form of early action credits or allocations that exceed actual emissions; and

- The government may not have accurate data on historic emissions.

Consequently, actual emissions are often less than the quantity of allowances distributed leading to the accumulation of a bank of unused allowances. The size of the allowance bank at any given time is difficult to determine - information on the units distributed is usually available but the quantity needed for compliance is not known for the same date. ${ }^{160}$ Estimates of the size of the allowance bank for different ETSs

159. Data covering 28 EU ETS members from 2008-16 indicate annual rates of emissions change between $+1.78 \%$ and $-7.84 \%$ with an overall average of $-2.89 \%$. Emissions by country are calculated by summing the emissions of all installations in each country as reported to the Union Registry. See, e.g., EU ETS UNION REGISTRY, CORRECTED TABLE OF VERIFIED 2016 EMISSIONS (2016) (reporting annual emissions by installation from 2008 through 2016). All of these countries had the same ETS design and allowance prices during that period, so the different rates reflect differences in the mix of participants, local economic conditions, and other policies.

160. The EU ETS, for example, distributes free allowances for the current year (say 2018) on February 28 and auctions other allowances at various times during the year. However, installations have until April 30 to surrender allowances to cover their actual emissions during the previous year (2017) and may use allowances already issued for the current year for that purpose, 
are provided in Table 10. All of these ETSs have accumulated allowance banks. The banks range in size from $15 \%$ to over $500 \%$ (five years) of the annual compliance obligation.

Table 10. Estimates of allowance banks accumulated by GHG ETSs

\begin{tabular}{|l|c|c|l|}
\hline \multicolumn{1}{|c|}{ Jurisdiction } & Period & Bank & \multicolumn{1}{|c|}{ Notes } \\
\hline EU ETS & $\begin{array}{c}2005- \\
2007\end{array}$ & $>15 \%$ & $\begin{array}{l}\text { Surplus allowances not valid } \\
\text { for post 2007 compliance }\end{array}$ \\
\hline & $\begin{array}{c}2008- \\
2016\end{array}$ & $>100 \%$ & $\begin{array}{l}\text { Use of Kyoto Protocol units } \\
\text { restricted }\end{array}$ \\
\hline Switzerland & $\begin{array}{c}2008- \\
2012\end{array}$ & $>100 \%$ & $\begin{array}{l}\text { Severe restrictions on post } \\
2012 \text { use of surplus 2008-12 } \\
\text { units }\end{array}$ \\
\hline & $\begin{array}{c}2013- \\
2016\end{array}$ & $>50 \%$ & $\begin{array}{l}\text { Use of Kyoto Protocol units } \\
\text { restricted }\end{array}$ \\
\hline RGGI & $\begin{array}{c}2009- \\
2011\end{array}$ & $>15 \%$ & $\begin{array}{l}\text { Unallocated and unsold } \\
\text { allowances withdrawn }\end{array}$ \\
\hline New Zealand & $2012-$ & $>50 \%$ & $\begin{array}{l}\text { Emissions cap reduced by } \\
\text { over 25\% }\end{array}$ \\
\hline California and & 2014 & $>500 \%$ & $\begin{array}{l}\text { Use of Kyoto Protocol units } \\
\text { banned after 2014. Bank } \\
\text { peaked at over 600\% in } \\
\text { 2015 }\end{array}$ \\
\hline Tokyo & 2016 & $>45 \%$ & Estimate by Busch, 2018 161 \\
\hline & $2010-$ & $>15 \%$ & \\
\hline
\end{tabular}

so it is difficult to calculate the number of surplus units at any particular time. See EUROPEAN COMM'N, supra note 28, at 101 (describing the compliance cycle).

161. See Chris Busch, Energy Innovation: Policy \& Tech. LlC, Oversupply GROWS IN WESTERN CLIMATE INITIATIVE CARBON MARKET: AN ADJUSTMENT FOR CURRENT OVERSUPPLY IS NEEDED TO ENSURE THE PROGRAM WILl ACHIEVE ITS 2030 TARGET 30 (2017) ("[T] he expected bank of allowances accumulated through 2020 is $26-45$ percent of cumulative WCI cap declines 2021-30."). 
Note that in Table 10, "Bank" at the end of the period is expressed as a percentage of the annual compliance obligation - annual emissions except for New Zealand where the compliance obligation is one unit for two tCO2 emitted. $100 \%$ means that the banked units are equal to one year's compliance obligation.

ETSs have utilized several measures to reduce the number of banked allowances, including:

- Effective cancellation of surplus allowances-cancellation of surplus European Union allowances (EUAs) at the end of Phase 1 of the EU ETS, severe restrictions on the quantity of 2008-12 Swiss allowances (CHUs) that can be used for 201320 compliance by Swiss ETS participants and withdrawal of unallocated and unsold units by state governments participating in RGGI;

- Severe restrictions on compliance use of external offset credits - after 2012 compliance use of Kyoto Protocol units was severely restricted by the EU and Swiss ETSs, and New Zealand prohibited their use after 2014;

- Larger reductions of the emissions cap-a reduction in the emissions cap by RGGI after 2009-12 and a shift from stable emissions limits to annual reductions in the limit by the California, EU, Quebec, RGGI and Swiss ETSs; and

- Delayed distribution of allowances-the EU ETS "backloading" provision deferred the distribution of allowances from 2014-16 to 2019-20.

In addition to the measures to reduce the allowance banks mentioned in Table 10, ETS designs have changed in ways that should reduce the accumulation of allowance banks. Many ETSs now have declining annual emissions caps, although the caps generally are declining more slowly than emissions (see Table 9) ${ }^{162}$ Market stability reserves to manage the size of allowance banks have been adopted by California-Quebec, EU and RGGI systems. While their designs differ, all of the stability reserves withdraw allowances from the market when the supply is abundant and release allowances if shortages arise. Data on the effectiveness of these mechanisms are not yet available.

Governments clearly have been cautious in setting the limits for their ETSs. However, emission reductions have occurred in most of the ETSs despite the accumulation of surplus allowances. In effect,

162. See Narassimhan et al., supra note 48, at 972 tbl.2 (displaying slight annual reductions in emissions caps across ETSs). 
participants assume that the ETS will continue and that the allowances will be eligible for future compliance use despite instances where surplus allowances have been discounted or cancelled. ${ }^{163}$

\section{Other assessments of the performance of GHG ETSs}

This section summarizes the findings of other studies that have assessed the performance of various GHG ETSs.

The California ETS has been criticized on the grounds that its treatment of imported electricity has led to leakage due to "resource shuffling", and that the bulk of the emission reductions stem from command-and-control regulations that apply to sources covered by the ETS. ${ }^{164}$

Evaluations of the New Zealand ETS concluded that it achieved only minimal reductions of net emissions below business-as-usual levels due to regulatory uncertainty and the ability to use unlimited quantities of low cost imported units for compliance. ${ }^{165}$

Alberta's SGER regulation was found to have "had no significant impact on annual emissions or the emission intensity of the average

163. Cancelling or discounting distributed allowances leads to an economic loss for the allowance owners, but the financial loss may be small since most allowances are distributed for free. Provisions governing the distribution of free allowances differ by ETS and change over time. The EU ETS distributed over $95 \%$ of the allowances free during the first (2005-07) and second (2008-12) phases. During the third (2013-20) phase free allowances are provided to industry sectors deemed to be exposed to carbon leakage, while the free allocation to other industries declines from $80 \%$ to $30 \%$ and electricity generators get no free allowances. See EUROPEAN COMM'N, supra note 28, at 23-25). RGGI, which covers only fossil-fired electricity generation, auctions over $90 \%$ of its allowances. See RAMSEUR, supra note 97 , at 2. California issues free allowances to industries but the allocations start to decline in 2018. Investor-owned electric and gas utilities get free allowances on behalf of their customers. During the first (2013-14) compliance period about $6 \%$ of the allowances were auctioned. See ICAP, USA CALIFORNIA CAP-AND TRADE PROGRAM 3 (2018). New Zealand provides intensity-based free allocation for eligible activities with $90 \%$ free allowances for highly EITE activities and $60 \%$ free allowances for moderately EITE activities. For the 2015-16 fiscal year, about $64 \%$ of allowances were distributed free. See ICAP, NEw ZEALAND EMISSIONS TRADING SCHEME 3 (2018). Between 2008 and 2012, each participant received a free allocation equal to its negotiated emissions target. Since 2013 the allocation process has been similar to that of the EU ETS. See ICAP, SWISS ETS 2 (2018). As baseline-and-credit systems, participants in the Alberta and Tokyo trading systems effectively receive a free allowance allocation equal to their baseline. The Chinese pilot trading systems distribute virtually all allowances for free. See Zhe Deng et al., supra note 11, at 994 tbl.1.

164. See, e.g., Guri Bang et al., supra note 29, at 24-25; Caron et al., supra note 63, at 32-33; Danny Cullenward, The Limits of Administrative Law as Regulatory Oversight in Linked Carbon Markets, 33 UCLA J. ENVTL. L. \& POL'Y 1, 17-18 (2015).

165. See N.Z. MinisTRY FOR THE ENV'T, supra note 41, at 40 ("The New Zealand ETS appears to have contributed, but only minimally, to changes in behavior and decisions that have reduced net emissions below business-as-usual levels."); see generally Leining et al., supra note 152 (discussing the history of the New Zealand ERS, outcomes, and pitfalls). 
regulated facility across any of the sectors except the pulp and paper industry." 166

RGGI has been assessed from several perspectives. During 200915 , electric power $\mathrm{CO}_{2}$ emissions and electricity prices declined in RGGI states, while in other states, emissions and prices increased. ${ }^{167}$ Between 2009 and 2012, RGGI is estimated to have been responsible for about half of the decline in the region's fossil-fired generating plant emissions. ${ }^{168}$ Lower natural gas prices, other environmental policies, and the 2009 recession were responsible for the rest. ${ }^{169}$ Use of auction revenue for energy efficiency, renewable energy, and other measures also contributed to the emission reductions. ${ }^{170}$ Part of the emissions reduction may have been offset by higher emissions in neighboring states. ${ }^{171}$ RGGI is providing positive economic impacts and public health benefits while meeting its emission reduction objectives. ${ }^{172}$

Reviews of the Swiss ETS conclude that the pressure on participants to reduce their $\mathrm{CO}_{2}$ emissions has practically vanished due to the abundant supply and consequent low prices of allowances. ${ }^{173}$ The

166. Deepak Rajagopal, Firm Behaviors and Emissions under Emissions Intensity Regulation: Evidence from Alberta's Specific Gas Emitters Regulation 1 (Oct. 17, 2014) (on file with UCLA Inst. Of Env't \& Sustainability, Working Paper Series) https://escholarship.org/uc/item/5t40p9ht.

167. Jordan Stutt et al., ACAdia Ctr., Regional Greenhouse Gas initiative STATUS REPORT: PART MEASURING SUCCESS 9 (2016).

168. See Murray \& Maniloff, supra note 8, at 588 ("[E]missions would be $24 \%$ higher in the region if the RGGI program were not in effect . . . about half of the region's reductions can be attributable directly to the RGGI program.”).

169. Id. at 583 .

170. Id. at 582 .

171. See Harrison Fell \& Peter Maniloff, Leakage in Regional Environmental Policy: The Case of the Regional Greenhouse Gas Initiative, 87 J. EnVTL. ECON. \& MGMT. 1, 17 (2018) ("[R]educed generation in the RGGI region was not compensated for by increase in gas-fired generation in the area, but rather RGGI led to an increase in generation from the areas surrounding RGGI.").

172. See Paul J. Hibbard et Al., Analysis GrP., The ECONOMic Impacts of the

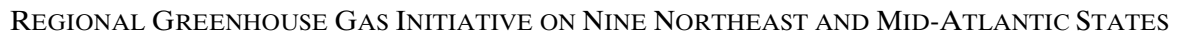
49 (2015) ("[M]arket-based programs are providing positive economic impacts while meeting emission objectives.”); Michelle MANiOn et Al., AbT Assocs., ANAlysis of THE PubliC HeAlth Impacts of the Regional GReEnhouse GAS Initiative, 2009-2014 1-3 (2017) ("The RGGI program improved air quality throughout the Northeast states and created major benefits to public health and productivity, including avoiding hundreds of premature deaths and tens of thousands of lost work days.").

173. FED. OfF. FOR THE ENV'T, EVALUATION OF INCENTIVE EFFECT OF EMISSIONS Trading SCHEME 9 (2015); see ZHAW Zurich U. OF APPLIEd SCI.-SCH. OF MGMT. \& L., SWISS EMISSIONS TRADING SCHEME CH ETS 5 (2018) ("The high amount of emission allowances allocated free of charge in combination with the currently low prices per unit provide little incentive for companies to implement reduction measures."). 
supply has been increased by the closure of a large emitter and the availability of imported compliance units. The situation is aggravated by uncertainties related to banking of surplus allowances and the possible link with the EU ETS (now agreed).

Not surprisingly, the EU ETS, the oldest and largest GHG ETS, has been the subject of the most numerous evaluations. ${ }^{174}$ The European Environment Agency and, in recent years, the European Commission publish annual reports on its operation. ${ }^{175}$ Numerous attempts to estimate the emission reductions achieved have been published over the past decade. These are summarized in Table 11. The table shows two groups of studies: studies that estimate the emission reductions achieved by the EU ETS, and estimates of national emission reductions.

174. See generally Noriko Fujiwara, Meta-Analysis of Climate Change Policy EVAlUations In THE EU AND MEMBER STATES (2017); Sean Healy et al., Review of Literature on EU ETS Performance: A Literature Review on GAP Analysis of Policy Evaluations (ÖkoInstitut, Working Paper No. 2/2015, 2015).

175. See generally Commission Report on the Functioning of the European Carbon Market, COM (2017) 48 final (Feb. 1, 2017); European Env't Agency, Rep. No. 18/2017, Trends and Projections in the EU ETS in 2017: The EU Emissions Trading System in Numbers (2017), https://www.eea.europa.eu/publications/trends-and-projections-EU-ETS-2017; ANDREI MARCU ET AL., EURopean Roundtable on Climate CHANGE AND SuStainable Transition ET AL., THE 2018 STATE OF THE EU ETS REPORT (2018). 
Table 11. Estimates of the emission reductions achieved by the EU ETS $^{176}$

\begin{tabular}{|c|c|c|c|c|}
\hline \multirow{2}{*}{$\begin{array}{l}\text { Time } \\
\text { Period }\end{array}$} & \multirow{2}{*}{ Methodology } & \multicolumn{2}{|c|}{$\begin{array}{c}\text { Emission } \\
\text { Reductions }\end{array}$} & \multirow{2}{*}{ Study } \\
\hline & & $\begin{array}{l}2005- \\
2007\end{array}$ & $\begin{array}{c}2008- \\
2012\end{array}$ & \\
\hline $\begin{array}{l}2005- \\
2006\end{array}$ & $\begin{array}{l}\mathrm{BAU}=\text { pre- } 2005 \\
\text { trend for emissions } \\
\text { intensity reduction, } \\
\text { about }-1 \% / \text { year }\end{array}$ & $\begin{array}{l}50 \text { to } 100 \\
\mathrm{MtCO}_{2} / \mathrm{y} \\
\text { ear }\end{array}$ & & $\begin{array}{l}\text { Ellerman and } \\
\text { Buchner, } \\
2008^{177}\end{array}$ \\
\hline $\begin{array}{l}2005- \\
2007\end{array}$ & $\begin{array}{l}\text { Ellerman and } \\
\text { Buchner } \\
\text { methodology. Same } \\
\text { result, expressed } \\
\text { differently }\end{array}$ & $\begin{array}{l}2 \text { to } 5 \% \\
\text { of } \\
\text { emissions }\end{array}$ & & $\begin{array}{l}\text { Ellerman, et } \\
\text { al. } 2010^{178}\end{array}$ \\
\hline $\begin{array}{l}2005- \\
2006\end{array}$ & $\begin{array}{l}\text { Fuel switching } \\
\text { emission reductions } \\
\text { using a power sector } \\
\text { model }\end{array}$ & \begin{tabular}{|l|}
75 \\
$\mathrm{MtCO}_{2} /$ \\
year
\end{tabular} & & $\begin{array}{l}\text { Delarue, et } \\
\text { al., } 2008^{179}\end{array}$ \\
\hline $\begin{array}{l}2005- \\
2007\end{array}$ & $\begin{array}{l}\text { Panel data } \\
\text { econometric analysis } \\
\text { used to estimate } \\
\text { BAU emissions } \\
\end{array}$ & $\begin{array}{l}247 \\
\mathrm{MtCO}_{2} \\
\text { over } 3 \\
\text { years } \\
\end{array}$ & & $\begin{array}{l}\text { Anderson and } \\
\text { DiMaria, } \\
2011^{180}\end{array}$ \\
\hline
\end{tabular}

176. Difference in difference estimates a relationship between the emissions of ETS plants and plants not subject to the ETS. These non-ETS plants are usually smaller plants in the same industry and serve as the control group. Difference in difference looks at both groups during a period prior to the start of the ETS and uses this relationship to estimate business-as-usual emissions of the ETS plants after the ETS starts using actual data for control group plants. Thus, the estimated emissions reflect actual economic conditions, fuel prices, and other policies; therefore, the difference between the estimated and actual emissions is due to the ETS. For a technical description of the methodology, see Sebastian Petrick \& Ulrich J. Wagner, The Impact of Carbon Trading on Industry: Evidence from German Manufacturing Firms 7-11 (Verein für Socialpolitik, No. C11-V3, 2014) and Marit E. Klemetsen et al., The Impacts of the EU ETS on Norwegian Plants' Environmental and Economic Performance 22-24 (Statistics Nor., Discussion Paper No. 833, 2016).

177. A. Denny Ellerman \& Barbara K. Buchner, Over-Allocation or Abatement? A Preliminary Analysis of the EU ETS Based on the 2005-06 Emissions Data, 41 ENVTL. \& RESOURCE ECON. 267, 286 (2008).

178. A. Denny Ellerman et al., Pricing Carbon: The European Union Emissions TRADING SCHEME 191 (2010).

179. Erik Delarue et al., Fuel Switching in the Electricity Sector Under the EU ETS: Review and Prospective, 134 J. ENERGY ENGINEERING 40 (2008).

180. Barry Anderson \& Corrado Di Maria, Abatement and Allocation in the Pilot Phase of the EU ETS, 48 ENV'T. \& RESOURCE ECON. 83, 97 (2011). 


\begin{tabular}{|c|c|c|c|c|}
\hline \multirow{2}{*}{$\begin{array}{l}\text { Time } \\
\text { Period }\end{array}$} & \multirow{2}{*}{ Methodology } & \multicolumn{2}{|c|}{$\begin{array}{c}\text { Emission } \\
\text { Reductions }\end{array}$} & \multirow{2}{*}{ Study } \\
\hline & & $\begin{array}{l}2005- \\
2007\end{array}$ & $\begin{array}{c}2008- \\
2012\end{array}$ & \\
\hline $\begin{array}{l}2005- \\
2008\end{array}$ & $\begin{array}{l}\text { Compares } 2005-06 \\
\text { and } 2007-08 \\
\text { reductions using } \\
\text { data for } 2,101 \text { firms }\end{array}$ & & $\begin{array}{l}\text { Phase II } \\
\text { led to } \\
\text { reduct- } \\
\text { ions }\end{array}$ & $\begin{array}{l}\text { Abrell, et al., } \\
2011^{181}\end{array}$ \\
\hline $\begin{array}{l}2005- \\
2009\end{array}$ & $\begin{array}{l}\text { Ellerman and } \\
\text { Buchner } \\
\text { methodology Phase } \\
\text { I results are base for } \\
\text { Phase II }\end{array}$ & $\begin{array}{l}\text { Intensity } \\
1 \% / \\
\text { year } \\
\text { lower }\end{array}$ & $\begin{array}{l}\text { Intensity } \\
1 \text { to } \\
5 \% / y r \\
\text { lower }\end{array}$ & $\begin{array}{l}\text { Egenhofer, et } \\
\text { al., 2011 }\end{array}$ \\
\hline $\begin{array}{l}2005- \\
2010\end{array}$ & $\begin{array}{l}\text { Analysis of } \\
\text { allowance allocation, } \\
\text { trade and surrender } \\
\text { by installation }\end{array}$ & & \begin{tabular}{|l} 
More \\
stringent
\end{tabular} & $\begin{array}{l}\text { Kettner, et al., } \\
2011^{183}\end{array}$ \\
\hline $\begin{array}{l}2005- \\
2012\end{array}$ & $\begin{array}{l}\text { Econometric } \\
\text { analysis of the } \\
\text { impact of the } \\
\text { recession on } \\
\text { emissions }\end{array}$ & \multicolumn{2}{|c|}{$\begin{array}{l}33 \text { to } 41 \mathrm{MtCO}_{2} \text { over } \\
8 \text { years due to ETS; } \\
12 \% \text { of total }\end{array}$} & $\begin{array}{l}\text { Bel and } \\
\text { Joseph, } \\
\text { 2015 }\end{array}$ \\
\hline $\begin{array}{l}2005- \\
2012\end{array}$ & $\begin{array}{l}\text { Econometric } \\
\text { analysis for a panel } \\
\text { of EU countries }\end{array}$ & \multicolumn{2}{|c|}{$\begin{array}{l}\text { Up to } 10 \%(100 \\
\left.\mathrm{MtCO}_{2}\right) \text { due to } \\
\text { carbon price. Rest } \\
\text { due to other policies } \\
\text { and recession }\end{array}$} & $\begin{array}{l}\text { Gloaguen and } \\
\text { Alberola, } \\
\text { 2013 }\end{array}$ \\
\hline
\end{tabular}

181. Jan Abrell et al., Assessing the Impact of the EU ETS Using Firm Level Data 15 (Bruegel Univ., Working Paper No. 2011/08, 2011).

182. Christian Egenhofer et Al., CTR. FOR Eur. POL'y Stud., The EU EMissions Trading System AND Climate Policy TOWARds 2050: REAL INCENTIVES TO REDUCE EMISSIONS AND DRIVE INNOVATION? 11 (2011).

183. Claudia Kettner et al., The EU Emission Trading Scheme Allocation Patterns and Trading Flows 3 (Austrian Inst. of Econ. Research, WIFO Working Papers No. 402, 2011).

184. Germà Bel \& Stephan Joseph, Emission Abatement: Untangling the Impacts of the EU ETS and the Economic Crisis, 49 ENERGY ECON. 531, 538 (2015).

185. Olivier Gloaguen \& Emilie Alberola, Assessing the Factors Behind CO2 Emissions Changes over the Phases 1 and 2 of the EU ETS: An Econometric Analysis 28 (CDC Climat Research, Working Paper No. 2013-15, 2013). 


\begin{tabular}{|c|c|c|c|c|}
\hline \multirow{2}{*}{$\begin{array}{l}\text { Time } \\
\text { Period }\end{array}$} & \multirow{2}{*}{ Methodology } & \multicolumn{2}{|c|}{$\begin{array}{c}\text { Emission } \\
\text { Reductions }\end{array}$} & \multirow{2}{*}{ Study } \\
\hline & & $\begin{array}{l}2005- \\
2007\end{array}$ & $\begin{array}{l}2008- \\
2012\end{array}$ & \\
\hline $\begin{array}{l}2005- \\
2014\end{array}$ & $\begin{array}{l}\text { Comparison of } \\
\text { energy intensity } \\
\text { decline pre and post } \\
2005\end{array}$ & \multicolumn{2}{|c|}{$\begin{array}{l}\text { Average decline } \\
3 \% / \text { year vs about } \\
1 \% / \text { year to } 2004\end{array}$} & $\begin{array}{l}\text { Ellerman, et } \\
\text { al. } 2016^{186}\end{array}$ \\
\hline & \multicolumn{3}{|c|}{ National Estimates } & \\
\hline $\begin{array}{l}2005- \\
2007\end{array}$ & $\begin{array}{l}\text { Ellerman and } \\
\text { Buchner } \\
\text { methodology Upper } \\
\text { bound estimates }\end{array}$ & $\begin{array}{l}85.5 \text { to } \\
121.9 \\
\mathrm{MtCO}_{2} \mathrm{e}\end{array}$ & & $\begin{array}{l}\text { Ellerman and } \\
\text { Feilhauer, } \\
2008^{187}\end{array}$ \\
\hline $\begin{array}{l}2001- \\
2013\end{array}$ & $\begin{array}{l}\text { Norway Difference } \\
\text { in difference with } \\
\text { plant data }\end{array}$ & Nil* & $\begin{array}{l}\text { Signif- } \\
\text { icant }\end{array}$ & $\begin{array}{l}\text { Klemetsen, et } \\
\text { al., 2016 }\end{array}$ \\
\hline $\begin{array}{l}1999- \\
2010\end{array}$ & $\begin{array}{l}\text { France Difference in } \\
\text { difference estimates } \\
\text { with plant data }\end{array}$ & $\begin{array}{l}\text { Insignif- } \\
\text { icant }\end{array}$ & $\begin{array}{l}15.7 \% \\
\text { since } \\
2005\end{array}$ & $\begin{array}{l}\text { Wagner, et } \\
\text { al., 2014 }\end{array}$ \\
\hline $\begin{array}{l}2003- \\
2010\end{array}$ & $\begin{array}{l}\text { Lithuania Difference } \\
\text { in difference } \\
\text { estimates with plant } \\
\text { data }\end{array}$ & Nil & Nil & $\begin{array}{l}\text { Jaraite and } \\
\text { DiMaria, } \\
2016^{190}\end{array}$ \\
\hline $\begin{array}{l}1995- \\
2010\end{array}$ & $\begin{array}{l}\text { Germany difference } \\
\text { in difference ests. w/ } \\
\text { plant data }\end{array}$ & Nil & $\begin{array}{l}20 \% \\
\text { reduction }\end{array}$ & $\begin{array}{l}\text { Petrick and } \\
\text { Wagner, } \\
2014^{191}\end{array}$ \\
\hline
\end{tabular}

186. A. Denny Ellerman et al., The European Union Emissions Trading System: Ten Years and Counting, 10 REV. ENVTL. ECON. \& POL'Y 89, 96-103 (2016).

187. A. Denny Ellerman \& Stephan Feilhauer, A Top-Down and Bottom-Up Look at Emissions Abatement in Germany in Response to the EU ETS 13 (Mass. Inst. of Tech. Ctr. for Energy \& Envtl. Pol'y Res., Working Paper No. 08-017, 2008).

188. See Klemetsen et al., supra note 176, at 38 ("Our estimation results suggest that the ETS may have led to significant emission reductions in the second phase (2008-12). However, we do not find any significant effects in the first phase (2005-07) or the third phase (2013)."). Also note that although Norway had an ETS with a design very similar to that of the EU ETS, it was not part of the EU ETS until 2008.

189. Ulrich J. Wagner et al., The Causal Effects of the European Union Emissions Trading Scheme: Evidence from French Manufacturing Plants 20 (2014) (on file with IZA Inst. of Labor Econ.), http://conference.iza.org/conference_files/EnvEmpl2014/martin_r7617.pdf.

190. J rate Jaraite \& Corrado Di Maria, Did the EU ETS Make a Difference? An Empirical Assessment Using Lithuanian Firm-Level Data, 37 EnERGy J. 1, 20 (2016).

191. Sebastian Petrick \& Ulrich J. Wagner, The Impact of Carbon Trading on Industry: Evidence from German Manufacturing Firms 34 (Kiel Inst. for the World Econ., Working Paper No. 1912, 2014). 
These studies indicate that the ETS reduced emissions relative to business-as-usual during its first phase. Those reductions appear to have been achieved mainly through fuel switching and efficiency measures in the power sector (about $60 \%$ of total emissions covered), with limited contributions by the industrial sectors.

Emission reductions during the second phase were larger, with industrial facilities contributing to the results. Other policies and economic developments make it very difficult to estimate the share of the reductions attributable to the ETS. During this period, EU implemented policies to achieve a $20 \%$ share of total energy consumption from renewable energy and a $20 \%$ improvement in energy efficiency to help achieve its target of a $20 \%$ reduction of GHG emissions from 1990 levels by 2020. A major recession in 2009 and changes to the relative prices of coal and natural gas over the period also affected emissions. ${ }^{192}$ Gloaguen and Alberola attribute a maximum of $10 \%$ of the reductions to the carbon price, but the ETS may also impact their energy efficiency variable, which accounts for a further $10 \%$ to $20 \%$ of the reductions. Results based on plant data, which compare emissions of ETS participants with those of plants not covered by the ETS, suggest the ETS contributed to the emission reductions achieved during Phase II.

Other impacts of the ETS, including employment, output, investment, profits, prices, leakage, and innovation, also have been the subject of multiple studies. ${ }^{193}$ In general, they find minimal, if any, adverse impacts together with shifts in investment, employment, and innovation toward less emitting activities.

\section{Summary}

We were able to compile emissions data for 10 ETSs covering 45 jurisdictions. Actual emissions declined for at least six of those ETSs. Emissions covered by the Alberta and New Zealand systems increased. It is clear that the 2009 recession, changes in the relative prices of coal

192. See Nicholas Berghmans et al., The CO2 Emissions of the European Power Sector: Economic Drivers and the Climate-Energy Policies' Contribution 12 (CDC Climat Research, Working Paper No. 2014-17, 2014) (showing natural gas prices rising while coal prices declined slightly, providing an incentive for greater use of coal and hence increased emissions).

193. Several studies provide helpful summaries. See, e.g., Ralf Martin et al., The Impact of the European Union Emissions Trading Scheme on Regulated Firms: What is the Evidence after Ten Years? 10 REV. ENVTL. ECON. \& POL'Y 129, 136-45 (2015); Tim Liang et al., Assessing the Effectiveness of the EU Emissions Trading System (Ctr. for Climate Change Econ. \& Pol'y, Working Paper No. 126, 2013). 
and natural gas, renewable energy and energy efficiency initiatives, and the nuclear plant shutdown following the great east Japan earthquake and tsunami have had significant impacts on the emissions covered by several of the ETSs.

All of the ETSs for which data are available have accumulated surplus allowances-some equivalent to more than a year's emissions. Most of those ETSs have implemented measures to reduce the surplus. In many cases, however, emissions continue to decline faster than the cap. Several of the ETSs have adopted market stability mechanisms to routinely remove surplus allowances from the market and inject allowances into the market when they are scarce. Data on the performance of these mechanisms are not yet available.

Other studies have attempted to estimate the emission reductions that can be attributed to the ETS. Murray and Maniloff estimate that RGGI was responsible for about half of the emissions reduction between 2009 and 2012. Several studies of the EU ETS suggest that emissions were reduced relative to business-as-usual during 2005-07, with most of the reductions due to fuel switching and efficiency measures in the power sector. Numerous studies conclude that the 2008-12 reductions were larger, with industrial facilities contributing to the results.

Assessments of the New Zealand and Swiss systems conclude that uncertainty adversely affected their performance. The uncertainty created by the challenge to the legality of the California ETS reduced the allowances sold at the May 2016 auction by almost $90 \%$. The court decision affirmed the legality of the ETS.

\section{COMPARISON OF ACTUAL CARBON TAXES AND GHG ETSS}

Existing carbon taxes and GHG ETSs are compared in Table 12 using the criteria proposed in Section III. ETSs perform better than carbon taxes on the principal criteria. Actual emission reductions are more common for ETSs, and the marginal cost is generally substantially lower. On average, ETSs cover a slightly larger share of the jurisdiction's GHG emissions. That assessment is subject to several caveats: First, some carbon taxes achieve emission reductions at marginal costs comparable to those of ETSs. Additionally, a few ETSs have not achieved emission reductions, and the observed emission reductions cannot be attributed solely to the ETS or tax. Evidence presented in section IV.B.3 suggests that other policies contributed significantly to the reductions of non-ETS emissions achieved by European countries with carbon taxes. Studies reviewed in section V.C 
indicate that other policies and economic developments likewise have helped reduce emission covered by GHG ETSs. Finally, ETSs and taxes are not included in the comparison due to lack of data.

Table 12. Comparison of Existing Carbon Taxes and GHG ETSs

\begin{tabular}{|c|c|c|}
\hline Criterion & Carbon Taxes & GHG ETSs \\
\hline $\begin{array}{l}\text { Principal } \\
\text { Criteria }\end{array}$ & & \\
\hline \multirow[t]{2}{*}{$\begin{array}{l}\text { Environmental } \\
\text { effectiveness: } \\
\text { Reduction of } \\
\text { actual } \\
\text { emissions in } \\
\text { the jurisdiction }\end{array}$} & $\begin{array}{l}6 \text { of } 17 \text { taxes in } 12 \\
\text { jurisdictions have } \\
\text { reduced actual } \\
\text { emissions since the start } \\
\text { of the tax. Other } \\
\text { policies probably } \\
\text { responsible for the } \\
\text { reductions of most } \\
\text { European taxes. }\end{array}$ & $\begin{array}{l}\text { At least six of ten ETSs } \\
\text { covering forty-one } \\
\text { jurisdictions have } \\
\text { reduced actual } \\
\text { emissions since } \\
\text { inception of the ETS. } \\
\text { Other policies } \\
\text { contribute, but their } \\
\text { share generally is not } \\
\text { known. }\end{array}$ \\
\hline & $\begin{array}{l}\text { Shares of the } \\
\text { jurisdiction's emissions } \\
\text { covered ranges from } 3 \% \\
\text { to } 70 \% \text { with a weighted } \\
\text { average of } 45.7 \%\end{array}$ & $\begin{array}{l}\text { Shares of the } \\
\text { jurisdiction's emissions } \\
\text { covered ranges from } \\
18 \% \text { to } 85 \% \text { with a } \\
\text { weighted average of } \\
48.0 \%\end{array}$ \\
\hline $\begin{array}{l}\text { Cost- } \\
\text { effectiveness: } \\
\text { low marginal } \\
\text { abatement cost }\end{array}$ & $\begin{array}{l}\text { Tax rates range from < } \\
\text { USD } 1 \text { to USD } 140 \text { with } \\
\text { a weighted average of } \\
\text { USD } 13.04 \text { per } \mathrm{tCO}_{2}\end{array}$ & $\begin{array}{l}\text { Allowance prices range } \\
\text { from < USD } 1 \text { to USD } \\
24 \text { with a weighted } \\
\text { average of USD } 7.79 \\
\text { per } \mathrm{tCO}_{2}\end{array}$ \\
\hline \multicolumn{3}{|l|}{$\begin{array}{l}\text { Secondary } \\
\text { Criteria }\end{array}$} \\
\hline $\begin{array}{l}\text { Economic } \\
\text { efficiency: Low } \\
\text { price volatility }\end{array}$ & $\begin{array}{l}\text { Tax rates are stable but } \\
\text { can change with } \\
\text { relatively little notice }\end{array}$ & $\begin{array}{l}\text { Many ETSs include } \\
\text { provisions to enhance } \\
\text { price stability and larger } \\
\text { ETSs tend to have } \\
\text { options and/or futures } \\
\text { contracts that enable } \\
\text { sources to obtain } \\
\text { allowances at an agreed } \\
\text { price at a future date }\end{array}$ \\
\hline
\end{tabular}




\begin{tabular}{|c|c|c|}
\hline Criterion & Carbon Taxes & GHG ETSs \\
\hline $\begin{array}{l}\text { Economic } \\
\text { efficiency: } \\
\text { price signal } \\
\text { commitment } \\
\text { into the future }\end{array}$ & $\begin{array}{l}\text { Commitments to future } \\
\text { tax rates tend to be } \\
\text { limited to } 3 \text { to } 5 \text { years } \\
\text { usually when the tax is } \\
\text { introduced. Annual rate } \\
\text { increases occur about } \\
60 \% \text { of the time. }\end{array}$ & $\begin{array}{l}\text { Commitments to cap } \\
\text { reductions and price } \\
\text { stability provisions ofter } \\
\text { span } 5 \text { to } 8 \text { years and } \\
\text { with emission reduction } \\
\text { targets to } 2030 \text { or } 2050\end{array}$ \\
\hline $\begin{array}{l}\text { Economic } \\
\text { efficiency: } \\
\text { harmonization } \\
\text { of marginal } \\
\text { costs across } \\
\text { jurisdictions }\end{array}$ & $\begin{array}{l}\text { International } \\
\text { harmonization of tax } \\
\text { rates is very complex } \\
\text { and has never been } \\
\text { attempted in practice }\end{array}$ & $\begin{array}{l}\text { Linking ETSs is } \\
\text { common but almost } \\
\text { always subject to } \\
\text { quantitative limits so } \\
\text { price convergence is } \\
\text { limited. Limits are } \\
\text { becoming more } \\
\text { stringent. }\end{array}$ \\
\hline $\begin{array}{l}\text { Public finance: } \\
\text { revenue raised }\end{array}$ & $\begin{array}{l}\text { Carbon taxes raise far } \\
\text { more revenue that } \\
\text { ETSs. Most tax revenue } \\
\text { is used for tax cuts and } \\
\text { rebates or general } \\
\text { revenue. Uses vary } \\
\text { widely by jurisdiction } \\
\text { and change over time. }\end{array}$ & $\begin{array}{l}\text { ETSs raise less revenue } \\
\text { than taxes because in } \\
\text { many ETSs most } \\
\text { allowances are } \\
\text { distributed free to EITE } \\
\text { sources. Most revenue is } \\
\text { used for green purposes } \\
\text { but this varies widely } \\
\text { across jurisdictions. }\end{array}$ \\
\hline $\begin{array}{l}\text { Public finance: } \\
\text { cross- } \\
\text { jurisdiction } \\
\text { revenue flows }\end{array}$ & $\begin{array}{l}\text { Cross-jurisdiction } \\
\text { revenue flows occur } \\
\text { through government } \\
\text { budgets }\end{array}$ & $\begin{array}{l}\text { In addition to } \\
\text { government transfers, } \\
\text { linking ETSs leads to } \\
\text { cross-jurisdiction } \\
\text { revenue flows } \\
\end{array}$ \\
\hline $\begin{array}{l}\text { Administrative } \\
\text { issues: } \\
\text { institutional } \\
\text { capacity }\end{array}$ & $\begin{array}{l}\text { Carbon taxes are often } \\
\text { relatively easy to } \\
\text { implement because } \\
\text { most jurisdictions } \\
\text { already collect taxes on } \\
\text { fossil fuels }\end{array}$ & $\begin{array}{l}\text { An ETS creates several } \\
\text { new institutional } \\
\text { requirements }\end{array}$ \\
\hline $\begin{array}{l}\text { Administrative } \\
\text { issues: } \\
\text { administrative } \\
\text { costs }\end{array}$ & $\begin{array}{l}\text { Administrative costs are } \\
\text { usually lower for carbon } \\
\text { taxes }\end{array}$ & $\begin{array}{l}\text { Administrative costs are } \\
\text { usually higher for ETSs }\end{array}$ \\
\hline
\end{tabular}




\begin{tabular}{|l|l|l|}
\hline Criterion & Carbon Taxes & GHG ETSs \\
\hline $\begin{array}{l}\text { Administrative } \\
\text { issues: } \\
\text { difficulty of } \\
\text { making } \\
\text { adjustments to } \\
\text { rules }\end{array}$ & $\begin{array}{l}\text { Changes to the tax rate } \\
\text { or coverage can } \\
\text { typically be made as } \\
\text { part of a budget }\end{array}$ & $\begin{array}{l}\text { Changes to the rules } \\
\text { governing an ETS tend } \\
\text { to require changes to } \\
\text { regulations and/or } \\
\text { legislation which often } \\
\text { involves a process of } \\
\text { notice and consultation }\end{array}$ \\
\hline $\begin{array}{l}\text { Administrative } \\
\text { issues: } \\
\text { minimization } \\
\text { of corruption }\end{array}$ & $\begin{array}{l}\text { Data on tax avoidance } \\
\text { are not available }\end{array}$ & $\begin{array}{l}\text { Information on the scale } \\
\text { of different forms of } \\
\text { corruption for ETSs is } \\
\text { not available. }\end{array}$ \\
\hline
\end{tabular}

Comparison of changes in non-ETS emissions in European countries with and without a carbon tax since 2008 suggests that the carbon taxes have had a limited impact in most of those jurisdictions. Other assessments of carbon taxes confirm that impression. Tax exemptions, relatively low tax rates (which lead to even smaller price changes), and modest changes to the tax rates limit the reduction of actual emissions achieved by carbon taxes. Most of those carbon taxes apply to residential, commercial, and transportation uses of fossil fuels - uses where consumers may not respond promptly or fully to the price changes induced by the tax.

More research is needed to improve instrument design. In the case of a carbon tax, it is conceptually clear that the tax rate must rise over time to adjust for inflation, increased income, technological change, and other factors to achieve further emission reductions. In practice rate increases for most carbon taxes have exceeded the rate of inflation, but for most of the taxes, that has not been enough to reduce emissions. The huge variation in tax rate changes and rates of emission reduction/increase indicate that this relationship is not well understood in practice.

Denmark, Iceland, Ireland, Norway, Slovenia (fluorinated gases tax only), Switzerland, and Liechtenstein regularly increase the tax rate at one- to three-year intervals; and

British Columbia, France, Japan, and the UK introduced carbon taxes with rapid (over 30\%/year) tax rate increases for periods of three to five years. Such rapid tax increases probably are not sustainable. ${ }^{194}$

194. The tax rates specified in the French legislation $-€ 56 / \mathrm{tCO} 2$ in 2020 and $€ 100 / \mathrm{tCO} 2$ in 2030 -imply that the average annual rate at which the tax rate rises falls from $31 \%$ for $2015-2020$ 
In British Columbia, they were followed by a five-year rate freeze. In the UK, the tax rate was frozen after three years. What will happen in other jurisdictions is not yet known.

Many of the ETSs accumulate significant quantities of surplus (banked) allowances and offset credits. A growing allowance bank indicates that emissions can be reduced faster than the rate at which the cap is declining. Since a growing bank depresses the market price, additional reductions can be achieved at relatively low cost. Many ETSs have implemented measures to reduce the surplus. Several ETSs have adopted a market stability reserve to remove excess allowances from the market when prices are low and release additional allowances into the market when prices are high. The effectiveness of those mechanisms will need to be assessed.

All jurisdictions with a carbon tax or GHG ETS have also implemented other policies that affect the emissions of sources covered by the instrument. Other policies can be justified if they have different objectives (e.g., short- vs. long-term emission reductions), they target different market failures (e.g., pollution abatement vs. technology innovation), or the carbon price is below the socially optimal level. ${ }^{195}$ The other policies may not cover the same sources and may affect them differentially, thus generating interaction effects. ${ }^{196}$ Although having multiple policies to reduce GHG emissions is inefficient, public opinion favors non-price policies so a portfolio of policies may be needed to sustain political support for price instruments. ${ }^{197}$

In the case of an ETS, any reductions achieved by other policies theoretically can be fully offset by higher emissions within the ETS cap, resulting in a higher cost for the same emission reduction. ${ }^{198}$ In the EU, subsidies for renewable energy are responsible for most of the emission

to less than 14\% for 2015-30. See Loi 2015-992 du 17 août 2015 relative à la transition énergétique pour la croissance verte [Law 2015-992 of August 17, 2015 on Energy Transition for Green Growth], JOURNAL OFFICIEl DE LA RÉpublique FranÇAise [J.O.] [OFFICAL GAZETTE OF FRANCE], Aug. 18, 2015, p. 14263.

195. Michael Mehling \& Endre Tvinnereim, Carbon Pricing and the $1.5^{\circ} \mathrm{C}$ Target: Near-Term Decarbonisation and the Importance of an Instrument Mix, 12 CARBON \& CLIMATE L. REV. 50, 57-59 (2018); Michael Hoel, Second-Best Climate Policy 2-3 (Univ. of Oslo, Dep't of Econ., Memorandum No. 04/2012, 2012), http://www.sv.uio.no/econ/english/research/unpublishedworks/working-papers/2012/memo042012.html; WORLD BANK CARBON PRICING LEADERSHIP COAL., supra note 77 , at 15-24.

196. See generally Wytze van der Gaast et al., Effects of Interactions Between EU Climate and Energy Policies (CARISMA, Working Documents No. 3, 2016) (discussing various case studies of the interactions between energy policies within different European countries).

197. BARRY G. RABE, CAN WE PRICE CARBOn? 24, 194, 208 (2018).

198. Schmalensee \& Stavins, supra note 12 , at 17-18. 
reductions in the power sector. ${ }^{199}$ In the German power sector, the combination of the renewable energy policy and EU ETS leads to larger emissions reductions due to their impacts on the merit order of fossil-fired generating units. ${ }^{200}$ In practice, some of the emission reductions achieved by other policies are captured by the removal/cancellation of surplus allowances and more rapid reduction of the emissions cap.

With respect to the economic efficiency criteria, carbon taxes provide better short-term price stability but poorer long-term price signals than ETSs. However, price stability provisions and, where available, forward contracts and options reduce short-term price volatility for ETSs. A carbon tax that has a track record of annual or biannual rate adjustments probably provides a longer-term price signal comparable to that of the five to eight-year cap reduction commitments of many ETSs.

Harmonization of tax rates or allowance prices only occurs where multiple jurisdictions are fully linked or part of the same ETS, as in the case of the EU ETS, RGGI and California/Quebec. Other ETSs have links but they are subject to qualitative and quantitative restrictions, which limit price convergence. Harmonization of effective tax rates would be very complex in practice and has not been attempted.

Carbon taxes raise significantly more revenue that ETSs. Indeed, that has been an important motivation for implementing a carbon tax in some jurisdictions. Many ETSs distribute most of their allowances free for two reasons: to ease the cost of adjusting to the new regulation, and to protect the competitiveness of EITE sources.

Free allowances provide an incentive to reduce emissions but reduce the financial cost of compliance, because a source whose emissions exceed its free allocation must purchase allowances to cover the excess, and a source whose emissions are less than its free allocation can sell its surplus allowances. Carbon taxes address these issues with exemptions, differential tax rates, and rebates. At least $44 \%$ of the carbon tax revenue is used for tax cuts and rebates. ${ }^{201}$ EITE

199. Nicholas Berghmans et al., The CO2 Emissions of the European Power Sector: Economic Drivers and the Climate-Energy Policies' Contribution 27 (Inst. for Climate Econ., Working Paper No. 2014-17, 2014).

200. Hannes Weigt et al., CO2 Abatement from Renewable Energy Injections in the German Electricity Sector: Does a CO2 Price Help? 27 (KULeuven Energy Inst., Working Paper EN2012002, 2012).

201. Carl \& Fedor, supra note 59, at 52. The percentages reported do not sum to 100 . When the percentages are calculated to sum to 100 , roughly $50 \%$ goes to tax cuts and rebates. Rebates probably go to entities, such EITE firms, subject to the tax while tax cuts are reductions of other 
exemptions might contribute to the lower share of emissions covered by taxes.

The ability of ETSs to facilitate cross jurisdictional financial transfers via allowance/offset purchases is interesting, but ETSs that allowed such imports, including the EU, Switzerland and New Zealand, have severely restricted their use. The newer ETSs in China and South Korea prohibit or tightly control imports of allowances and offsets from foreign jurisdictions.

A carbon tax is usually easier to implement and less costly to administer than an ETS. An ETS requires a new administrative infrastructure including: an emissions MRV system; institutions to distribute allowances, enforce compliance, and monitor the allowance market; and a computer registry to track allowance holdings. A carbon tax is usually applied to fossil fuels which are already subject to various taxes. Adding a carbon tax may involve changes to the MRV system and compliance enforcement. Extending the carbon tax beyond fossil fuels increases its complexity and administrative cost. Although the administrative costs of an ETS are generally considered to be higher than those for a carbon tax, the proliferation of ETSs indicates administrative costs are not a significant barrier.

It is interesting to note that ETSs are much more common for subnational jurisdictions than carbon taxes despite the extra administrative capacity they require. The sub-national ETSs are found in Canada, China and the US, and the choice of an ETS might be influenced by the constitutional distribution of taxing authority in those countries.

\section{CONCLUSION}

Carbon taxes and GHG ETSs are becoming increasingly common and now cover over $20 \%$ of global emissions. The first carbon taxes date from 1990 and the first GHG ETS still operating dates from 2005. Since 2005, implementation of ETSs has spread more rapidly. They now cover substantially more jurisdictions and more emissions than carbon taxes. Their designs vary widely. The instrument choice and design are affected by circumstances unique to the jurisdiction, such as its emissions profile, constitutional provisions, economic structure, and other policies.

taxes. Carl and Fedor group them even though the public finance and economic impacts are quite different. 
At the end of 2015, 17 GHG ETSs were operational in 55 jurisdictions, while 18 jurisdictions collected at least one carbon tax. Despite the number of taxes and ETSs implemented and the fact that several have been in effect for over a decade, relatively little is known about their actual performance.

Both carbon taxes and GHG ETSs have demonstrated that they can reduce emissions from business-as-usual. This paper proposes and applies the more stringent criterion of a reduction of actual emissions subject to the instrument. That approach permits assessment of more carbon taxes over longer time periods. It is also more consistent with the emissions targets of most jurisdictions that have implemented a carbon tax and/or ETS. The business-as-usual emissions reductions achieved are rarely sufficient to lower actual emissions.

So far, reductions of actual emissions are more common for ETSs than taxes, and, on average, allowance prices are lower than carbon tax rates. The observed emission reductions cannot be attributed solely to the ETS or tax. Other policies and other developments affect the emissions covered by the instruments. The effects of the 2009 economic recession and the nuclear plant shutdown after the great east Japan earthquake and tsunami are evident in the data. Additionally, data for EU countries suggest that the policies to improve energy efficiency and increase the supply of renewable energy have contributed to the declining emissions subject to both carbon taxes and the EU ETS. More rigorous analysis is needed to determine the emission reductions that can be attributed to the instruments.

The smaller emission reductions with higher marginal costs for carbon taxes may reflect the sources to which carbon taxes and GHG ETSs are applied. Carbon taxes tend to apply to fossil fuels with limited coverage of energy and industrial sources while the opposite is true for ETSs. The low price elasticity of demand for fossil fuels means that reduction of the associated emissions may require larger price changes (higher carbon taxes) and take longer than energy and industrial emission reductions covered by ETSs.

Measures to improve effectiveness are being developed and diffused more quickly for ETSs than for carbon taxes. Most ETSs have increased the share of allowances auctioned, adopted declining emissions caps, specified future caps and floor prices several years into the future, shifted to benchmarking for free EITE allowances, reduced the accessibility of foreign offset credits, and established market stability reserves. Experience has been shared bilaterally and via dedicated institutions including the International Carbon Action 
Partnership (ICAP), Western Climate Initiative, and Partnership for Market Readiness (PMR). ${ }^{202}$

In contrast, there has been virtually no change to the design of carbon taxes. Adjustments to the tax rate are unpredictable after the introductory period in most jurisdictions. We found no jurisdiction that regularly reports emissions by sources subject to its carbon tax(es). Very few jurisdictions regularly assess the effectiveness of the tax in achieving their emission reduction targets. Moreover, there is little evidence of shared learning based on experience, although the Partnership for Market Readiness is developing materials on the design and implementation of carbon taxes.

Interesting patterns for which we do not have an explanation include:

Most carbon taxes are implemented by national jurisdictions in countries that also have an ETS - countries that are part of the EU ETS and Switzerland. On the other hand, roughly the same number of countries that participate in the EU ETS do not have a carbon tax; and

Despite the greater administrative infrastructure required by an ETS, they are much more common than carbon taxes for sub-national jurisdictions. That may reflect the constitutional distribution of taxing authority in Canada, China and the US. In any case, the extra administrative demands are not a significant practical barrier to implementation of an ETS.

Topics that warrant further research to improve the effectiveness of these instruments include: the characteristics of a tax rate strategy that leads to actual emission reductions; the level of the tax rate needed to have an impact on emissions, the frequency and magnitude of tax rate changes needed to achieve continual reductions efficiently, and the commitments to future tax rates that provide credible price signals for mitigation investments; The most effective treatment of EITE sources under each instrument (is allocation of free allowances under an ETS more effective than an exemption/rebate under a tax?); and the design features of an effective ETS (do a commitment to a declining annual cap, price stability provisions, market stability reserve, links with other ETSs, or other features have a significant impact on the emission reductions achieved?)

202. See generally The Evolution of CARbon MARKETS: Design AND DifFusion (Jørgen Wettestad \& Lars H. Gulbrandsen eds., 2017). 
Research on effective portfolios of price and non-price instruments is needed. All jurisdictions with a carbon tax or GHG ETS have also implemented other policies that affect the emissions of sources covered by the instrument. There are sound theoretical and practical reasons for using multiple price and non-price instruments to address climate change. Use of multiple instruments produces complex interactive and distributional effects. While economically inefficient, a portfolio of price and non-price policies may be needed to sustain political support for price instruments. ${ }^{203}$

Both carbon taxes and GHG ETSs have demonstrated that they can reduce emissions. Implementation of both instruments is spreading. Given evidence available from existing instruments, it is time to learn from that experience to make both more effective so that they can better contribute to the effort to reduce global GHG emissions.

203. See RABE, supra note 197, at 24 ("[C]arbon pricing policies consistently have the most limited base of political support among a wide range of policy options to reduce carbon emissions."). 
Annex 1. Tax Revenue, Tax Rate, and Estimated Emissions by Jurisdiction and Tax, 1991 to 2016

\begin{tabular}{|c|c|c|c|c|c|c|c|c|}
\hline & 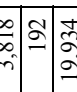 & \begin{tabular}{|c|}
\multicolumn{2}{|c|}{} \\
$\mathrm{m}$ \\
$\mathrm{n}$
\end{tabular} & $\hat{q}$ & $\begin{array}{lll}\Delta & \infty & \infty \\
\sim & \infty & 0\end{array}$ & & 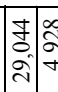 & 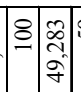 & $\therefore=\mid \begin{array}{ll}8 \\
\dot{d}\end{array}$ \\
\hline & & \begin{tabular}{|c|} 
\\
0 \\
0 \\
$i$ \\
\end{tabular} & & $\begin{array}{l}\vec{n} \\
6 \\
0\end{array}$ & 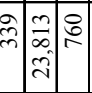 & $\mid \begin{array}{c}\hat{e} \\
\bar{m} \\
\bar{m}\end{array}$ & 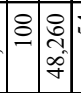 & $\stackrel{n}{*}=\underset{\sim}{\infty}$ \\
\hline & 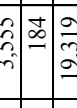 & 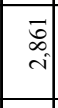 & 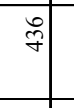 & | & 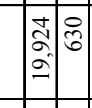 & 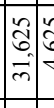 & 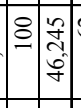 & 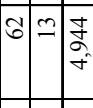 \\
\hline & & 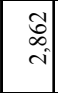 & $\tilde{q}$ & 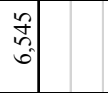 & \begin{tabular}{l|l}
0 \\
$\vdots$ \\
0 \\
0
\end{tabular} & 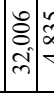 & 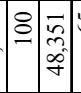 & $\therefore=\frac{n}{n^{2}}$ \\
\hline & & 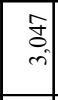 & $\hat{q}$ & . & & 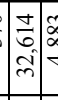 & 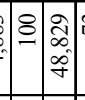 & $\therefore=\underset{\infty}{9}$ \\
\hline & $\hat{f}=\left\{\begin{array}{l}\infty \\
\hdashline \\
\frac{\pi}{\pi}\end{array}\right.$ & \begin{tabular}{|c|}
$\overrightarrow{0}$ \\
nె. \\
\end{tabular} & $\overline{\mathrm{a}}$ & 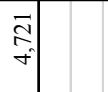 & & 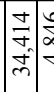 & 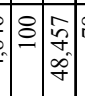 & $\therefore=\frac{2}{6}$ \\
\hline & $\stackrel{\bar{\sigma}}{\circ}$ & స్ & $\Sigma$ & $\Sigma$ & & 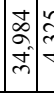 & 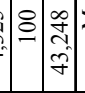 & $\Sigma \cong \Sigma$ \\
\hline & 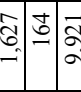 & 告 & $\Sigma$ & $\Sigma$ & & & & $\Sigma+$ \\
\hline & 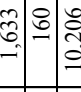 & 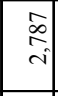 & $\Sigma$ & $\Sigma$ & & 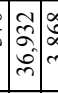 & {$\left[\begin{array}{c}0 \\
0 \\
0 \\
0 \\
0 \\
0 \\
0\end{array}\right.$} & \\
\hline & 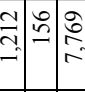 & 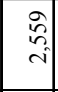 & $\Sigma$ & $\Sigma$ & & $\left|\begin{array}{c}0 \\
0 \\
0 \\
0 \\
0 \\
0\end{array}\right|$ & 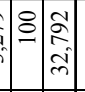 & \\
\hline & 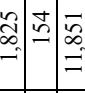 & $\begin{array}{l}\tilde{n} \\
\hat{n} \\
i \\
\end{array}$ & $\Sigma$ & $\Sigma$ & & 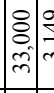 & 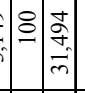 & \\
\hline & & $\Sigma$ & $\bar{\Sigma}$ & $\Sigma$ & & 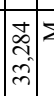 & $\approx \Sigma$ & \\
\hline & & $\Sigma$ & $\bar{\Sigma}$ & $\bar{z}$ & $\bar{z}|\overline{\grave{n}}|$ & & & \\
\hline & & $\Sigma$ & $\Sigma$ & $\bar{z}$ & $\bar{a}$ & & & \\
\hline & 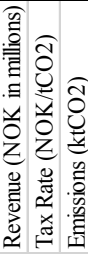 & 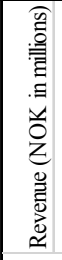 & 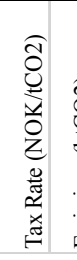 & 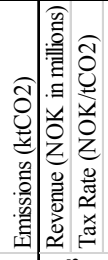 & 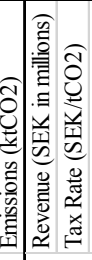 & & 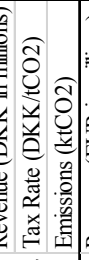 & 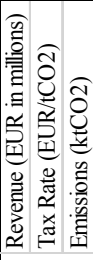 \\
\hline & 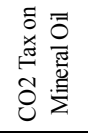 & 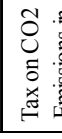 & 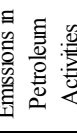 & 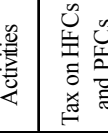 & $\begin{array}{l}\tilde{0} \\
0 \\
\vdots \\
\vdots \\
\text {. } \\
\end{array}$ & & $\begin{array}{l}\tilde{8} \\
0 \\
\overline{0} \\
\text { 言 } \\
\end{array}$ & 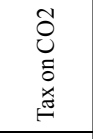 \\
\hline & & & $\bar{z}$ & & $\Sigma^{\prime}$ & & 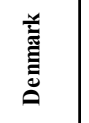 & $\frac{\pi}{\frac{m}{m}}$ \\
\hline
\end{tabular}


Fall 2018] CARBON TAXES \& EMISSIONS TRADING SYSTEMS

181

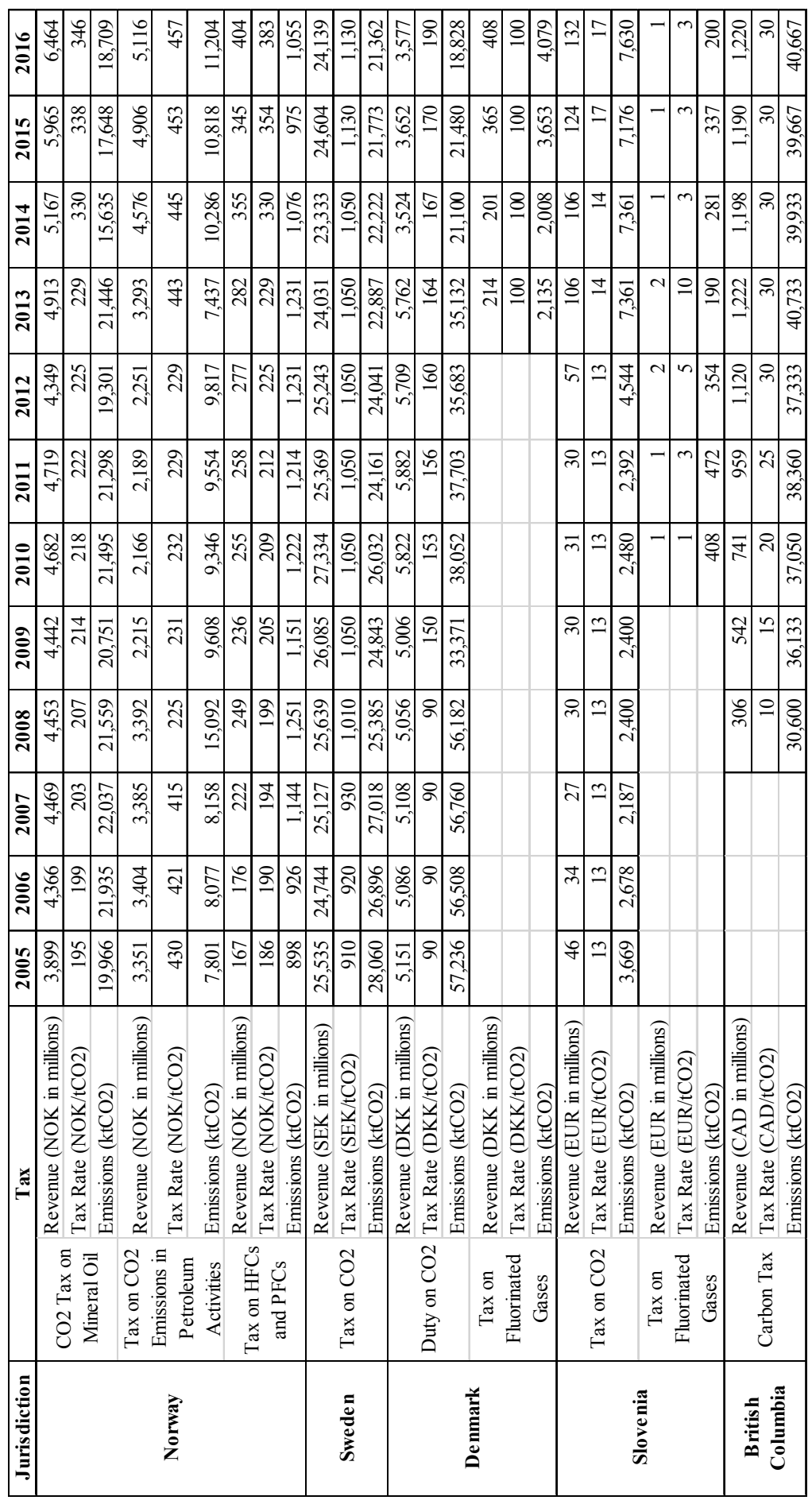




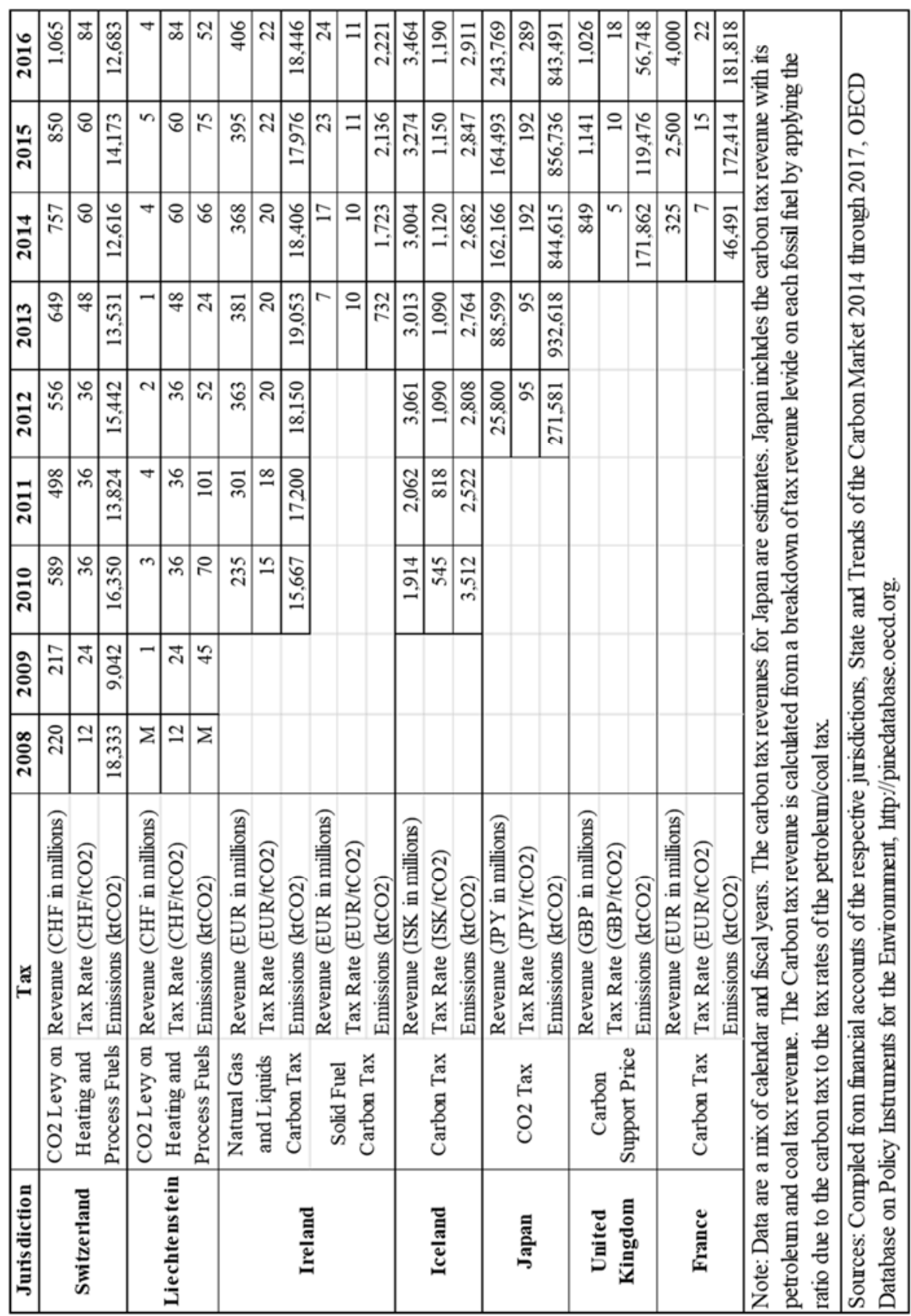

